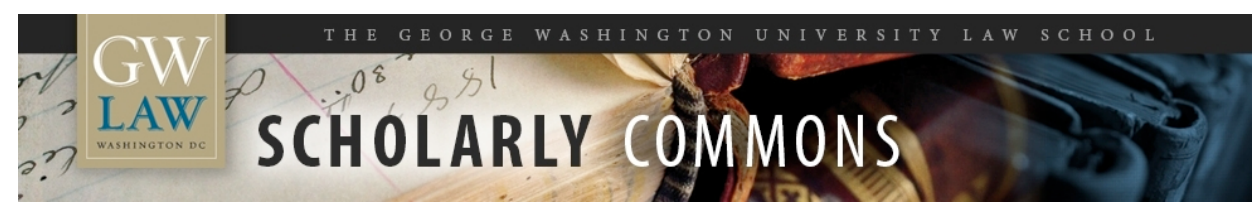

GW Law Faculty Publications \& Other Works

Faculty Scholarship

2000

\title{
Family Leave and the Gender Wage Gap
}

Michael Selmi

George Washington University Law School, mselmi@law.gwu.edu

Follow this and additional works at: https://scholarship.law.gwu.edu/faculty_publications

Part of the Law Commons

\section{Recommended Citation}

Michael Selmi, Family Leave and the Gender Wage Gap, 78 N.C. L. Rev. 707 (2000).

This Article is brought to you for free and open access by the Faculty Scholarship at Scholarly Commons. It has been accepted for inclusion in GW Law Faculty Publications \& Other Works by an authorized administrator of Scholarly Commons. For more information, please contact spagel@law.gwu.edu. 


\title{
FAMILY LEAVE AND THE GENDER WAGE GAP
}

\author{
by
}

\section{Michael Selmi*}

The patterns tied to both the reality and the assumptions regarding women's labor force behavior suggest that if there is to be greater equality for women in the workplace, it will be necessary for men to change their behavior, both in and out of the workplace, in order for employers to begin to change theirs. Despite improvements over the last two decades, including significant changes in women's labor force behavior, gender inequality continues to pervade, and in many ways define, the American workplace. The problem persists because men have not yet changed their behavior, and employers continue to exact penalties on women both because of their actual behavior, which differs from men's, but also based on their expectation that women will leave the workforce when they have children. Making more progress on workplace equality will require prodding men to act more like women, rather than trying to induce women to act more like men. In this way, we will create a new workplace norm where employees will be expected to have and spend time with their children and employers will adapt to that reality.

As an indication of just how much women's labor force behavior has changed, seventy-five percent of women between the ages of 20 and 54 now work, ${ }^{1}$ including sixty-five percent of women with children under

* Professor of Law, George Washington University Law School. Earlier versions of this paper were presented at the 1999 Law and Society Conference, Villanova Law School and a faculty workshop at George Washington University Law School. I am grateful for the comments I received at those presentations, as well as helpful comments on prior drafts from Naomi Cahn, Catherine Fisk, Larry Mitchell, and Joan Williams. Eungyoung Shin provided excellent research assistance, and Leslie Lee contributed tremendously with her indefatigable library assistance.

1 See U.S. DePt. of LABOR, BUREAU OF LABOR Statistics, EMPLOYMENT AND EARNINGS, Table 8 (1999). The vast majority of female workers work full-time. Based on data for 1993, approximately $16 \%$ of female workers worked part-time, defined as thirty-five or fewer hours. See Marianne A. Ferber \& Jane Waldfogel, The Long-Term 
age six. ${ }^{2}$ Nevertheless, women still earn between seventy and seventyfive percent of what men earn. ${ }^{3}$ Working women also continue to perform between two to three times as much housework as men, are still overwhelmingly responsible for child rearing, and occupy different jobs than men. ${ }^{4}$ They also lag far behind in positions of power, for example, accounting for only eight percent of the directors on Wall Street as of 1996.5

An important reason why we have failed to make more progress on issues of gender equity, is that as a society we have paid woefully little attention to the issue, in large part because we remain conflicted over women's role in the workplace. ${ }^{6}$ The United States has one of the

Consequences of Nontraditional Employment, 121 MONTHLY LABOR RVw. 3, 4-5 (1998).

2 See U.S. DePt. of LABOR, BUREAU OF LABOR Statistics, EMPLOYMENT CHARACTERISTICS OF FAMILIES IN 1998, Table 4 (1999) (reporting women with children's labor force participation).

${ }^{3}$ For a discussion of the wage gap see section I infra.

${ }^{4}$ These issues are discussed in greater detail infra at text accompanying notes 7074 (housework) and notes 105-07 (occupational segregation). For a recent informative discussion on houswork see Chloe E. Bird, Gender, Household Labor and Psychological Distress: The Impact of the Amount and Division of Housework, 40 J. OF HEALTH \& SOCIAL BEHAVIOR 32, 38 (1999), and for a recent discussion of the question of occupational segregation see Francine D. Blau, Patricia Simpson, \& Deborah Anderson, Continuing Progress? Trends in Occupational Segregation in the United States Over the 1970s and 1980s, 4 FEMINIST ECON. 29 (1998).

5 See Virginia VALIAn, Why So SLOW? 7 (1997). In this article, I will not focus on gender issues that arise in promotions, although much of the story would be similar to the one I discuss. For a discussion on the issue of the glass ceiling see U.S. DEPT. OF LABOR, GLASS CEILING COMMISSION, GOOD FOR BUSINESS: MAKING FULL USE OF THE NATION'S HUMAN CAPITAL (1995).

${ }^{6}$ For example, a 1998 poll conducted found that $40 \%$ of the respondents would like to return to the gender roles of the 1950s. See Richard Morin, With More Equity, More Sweat, WASHINGTON Post, Mar. 22, 1998 at A1 (reporting that "4 in 10 of those surveyed said, it would be better to return to the gender roles of the 1950s."). 


\section{Family Leave and the Gender Wage Gap}

highest female labor force participation rates among industrial countries, but it also has done the least to assist those women with the demands of work and family. As is well known, the United States was one of the last industrialized countries to adopt a family leave law and even today offers the least generous family leave benefits. ${ }^{7}$

The weakness of our commitment to facilitating work and family issues can be highlighted by examining our expenditures on other workplace benefits. As a society, we spend more than $\$ 50$ billion annually on workers' compensation, with another $\$ 20$ billion devoted to unemployment benefits, ${ }^{8}$ and legally mandated benefits now account for nearly 10 percent of payroll costs. ${ }^{9}$ In addition to these workplace benefits, we subsidize health insurance and pensions, as well as nonworkplace items such as home mortgages, all of which costs billions of dollars annually. And yet, when it comes to facilitating family leave as a way of providing some balance between work and family, on the federal level we spend practically nothing primarily because we are concerned about the effects the costs might have on employers and wages.

7 Jane Waldfogel recently summarized the legislation, "Until the passage of the Family and Medical Leave Act in 1993, the United States had no national maternity leave policy, and even now, it is tied with Switzerland in offering the shortest period of leave ... Moreover, the United States is the only country of [the 15 industrial countries surveyed] that does not offer some degree of paid leave." See Jane Waldfogel, Understanding the "Family Gap" in Pay for Women and Children, 12 J. OF ECON. PERSPECTIVES 137, 14041 (1998). For a comprehensive review of European and Canadian leave policies see KIRSTEN S. WEVER, ASSESSING TEMPORARY WAGE REPLACEMENT FOR FAMILY AND MEDiCAL LEAVE 7-10 (1996). Wever notes that as of 1989, "[s]ixteen European countries and Canada mandate an average of 33 weeks of paid maternity/parental leave ..." Id. at 8 .

${ }^{8}$ See NATIONAl ACADEMy OF SOCIAL InSURANCE, WORKER's COMPENSATION: Benefits, Coverage \& Costs 1994-95 at 8 (1997); Daniel McMurrer \& Amy B. Chasanov, Trends in Unemployment Benefits, 118 MONTHLY LABOR RVw. 30, 30 (1995) ("In 1993, more than $\$ 22$ billion was paid in [unemployment] benefits.").

9 See William J. Wiatrowski, Tracking Changes in Benefit Costs, COMPENSATION \& WORKING CONDITIONS 32, 33-34 (1999) (nothing that legally-required costs accounted for $9.6 \%$ of payroll costs in 1998 compared to $4.1 \%$ in 1959). 


\section{Family Leave and the Gender Wage Gap}

Increasing our societal commitment to family leave issues is critically important for at least two closely related reasons. First, if we are to make greater progress on gender equality in the workplace - progress that I will demonstrate is still much needed - we must challenge the existing stereotypes surrounding family leave, which invariably negatively impact women. As we will see, women are expected to be both at work and at home, and it is generally expected that their work at home will adversely affect their performance in the workplace. To close the gender gap further, we need to take steps to disrupt both the reality and the expectations of how women's relation to their children affects their labor market behavior and rewards. Second, creating a workplace where it is expected that workers will have, and take care of, children is essential to furthering our societal interest in the family.

The Family and Medical Leave Act ("FMLA") was one effort, and to date the only federal effort, to provide some much needed relief to working parents. ${ }^{10}$ However, because the Act offers such limited benefits - unpaid leave for up to twelve weeks following the birth or adoption of a child - it has failed to ease the burden on women, and indeed the Act's effects have likely been more negative than positive. Since the passage of the FMLA in 1993, no significant state family leave legislation has been enacted, even though there was a trend prior to the Act's passage toward implementing state leave policies that were more generous than the FMLA. ${ }^{11}$ In addition, recent data indicate that very few workers utilize the federal legislation, and women are considerably more likely than their male counterparts to avail themselves of the statutory leave provisions. ${ }^{12}$ Accordingly, in the eyes of employers, family leave remains

10 See Family and Medical Leave Act of 1993, Pub. L. No. 103-3, 107 Stat. 6, codified at sections $2 \& 5$ of 29 U.S.C.

11 See text accompanying notes 215-17.

12 The federal government commissioned two studies to assess the impact of the FMLA which are summarized in UNITED STATES DEPARTMENT OF LABOR, A WORKABLE BALANCE (1998). I discuss this report in section II.B. infra. 


\section{Family Leave and the Gender Wage Gap}

a woman's issue, one for which all women are being penalized in the marketplace.

This latter point relates to the persistence of the gender wage gap, a central focus of this article. Contributing, indeed perhaps explaining the bulk of workplace disparities based on gender, is a fact that plainly resists change: women continue overwhelmingly to be primarily responsible for childcare and child rearing. Despite the passage of the FMLA, and despite the frequent claim by men that they would like more time to be involved with their families, ${ }^{13}$ strikingly few men take any significant paternity leave or assume equal responsibility for child rearing. And thus, things continue largely as they were - women have less of an attachment to the labor force than men (though the differences are narrowing), they miss more work than men, take more time off when they have children, and generally work fewer hours, all of which contribute to a cumulative disadvantage, one that exacts a heavy price in terms of salary, promotions and workplace responsibility. ${ }^{14}$ Economist Claudia Goldin recently estimated that only about thirteen percent of college educated women

${ }^{13}$ Nearly every poll suggests that men would like to take more family leave, and would be willing to trade some income for more time with their family. See, e.g., Ellen Galinsky, Jjames T. Bond \& Dana E. Friedman, The Role of Employers in Addressing the Needs of Employed Parents, 52 J. OF Social IsSUES 111, 116-18 (1996) (both men and women would prefer to work less, and both equally likely to trade salary for greater child assistance benefits); ALAN WOLFE, ONE NATION AFTER ALL 244 (1997) (noting that many of the respondents "believed companies that turn employees into workaholics violated the moral principle of balance, as do people who neglect their family ties for higher income and occupational prestige"); Lisa Belkin, Bars to Equality of Sexes Seen as Eroding, Slowly, NEW YORK TIMES, at A26 (Aug. 20, 1989) (reporting that 40\% of men surveyed said they would quit their job to spend more time with their children). A recent poll also indicated that men and women supported (by substantial margins) expanding the Family and Medical Leave Act to small employers, and providing some form of insurance to cover family leave. See NATIONAL PARTNERSHIP FOR WOMEN AND FAMILIES, FAMILY MatTers: A National SurVey OF WOMEN AND MEN, Table 7 (1998).

${ }^{14}$ For an excellent recent discussion of the cumulative disadvantage see VALIAN, supra note 5 . 


\section{Family Leave and the Gender Wage Gap}

successfully attained both family and career by midlife. ${ }^{15}$

Even those women who do not have children or who experience very short exits from the labor market when they do have children are adversely affected by what is often labeled statistical discrimination the use of group statistics as proxies for information, in this instance the likelihood that more women than men will leave the workforce to have children with the further assumption that the accompanying labor force disruption will negatively impact productivity. ${ }^{16}$ Employers often treat women differently because as a group women do act differently from their male counterparts, even though the majority of women now vary from the hypothesized female employment path.

If we are to make more progress, it will be necessary for men to change their behavior in the labor market by, at a minimum, taking more leave around the birth or adoption of their children. Yet, history suggests that accomplishing this change will be no easy feat. Since at least the 1960 s, women as a group have altered their labor market behavior substantially, whereas the change for men has been marginal at best. ${ }^{17}$ Exhorting men to become more involved with family life, or touting the importance of families, is thus unlikely to ease the burden on women to any significant extent. To try to get at this dilemma, I will propose that the FMLA be amended so as to create greater incentives for men to take leave around the birth or adoption of a child. These proposed

15 Claudia Goldin, Career and Family: College Women Look to the Past, 45-48 in GENDER \& FAMILY ISSUES IN THE WORKPLACE (Francine Blau \& Ronald Ehrenberg eds. 1997).

16 See infra section II.

17 See, e.g., Joyce Gelb \& Marian Lief Palley, Women AND Public POLICIES: REASSESSING GENDER POLITICS 211 (1996) (“"D]espite increased social acceptance of work for women, the role of women in home and family has remained largely the same ...”); JOAN K. PETERS, WHEN MOTHERS WORK 10 (1997) (“Most women make more than the necessary changes when they have children; most men make none.”). 


\section{Family Leave and the Gender Wage Gap}

amendments will vary from forcing men to take six weeks of paid leave, to the less drastic measure of creating a governmental contract set-aside program aimed at rewarding employers who succeed in encouraging their employees to take family leave. ${ }^{18}$ As a means of justifying these proposals, I will demonstrate that outside of Sweden, where success is higher than anywhere else but lower than is often suggested, men have never voluntarily taken significant amounts of child-related leave, and the disproportionate burden that falls on women explains a substantial portion of their labor market inequality. Indeed, I will suggest that little short of forcing men, or creating strong incentives aimed at employers, will suffice to alter workplace patterns in a way that will enable women to make greater progress.

Equally important, creating ways through which men may become more involved in child rearing should have the effect of transforming the workplace so that the female model of the worker, rather than the male model, becomes the norm. If men begin to act more like women, employers may come to expect their employees to undertake the responsibilities of child rearing and to accommodate that responsibility more than they have so far been willing to do. Assuming such a transformation were possible, family leave benefits would then become part of the standard package of employee benefits, something akin to worker's compensation, or health and safety regulations, which today are seen as an integral part of doing business despite their costs.

It is surely possible to address the topic of family leave and workplace inequality from a number of perspectives, and in this article, I will concentrate on childbearing leave and will say little directly about child rearing, which also likely plays a significant role in furthering workplace inequality. I focus on childbearing for two reasons, and there is a third subsidiary reason that likewise supports my choice. First, leave following the birth of a child is already part of the policy agenda as a result of the FMLA and therefore is currently involved in the debate over

18 See sections III.B. infra. 


\section{Family Leave and the Gender Wage Gap}

attaining some balance between work and family. At this time, it seems far more difficult to create a workable plan relating to child rearing, given that it is ongoing and less predictable than childbearing. Second, the data indicate that much of the inequity that continues to define the workplace revolves around childbearing rather than child rearing. Most economic explanations and assumptions regarding why women receive lower wages are tied to the likelihood that a woman will leave the workforce when she has a child. This is true with respect to the human capital explanation involving investments in education, experience and training, as well as theories of statistical discrimination, both of which will be discussed in detail shortly. In contrast, child rearing plays a lesser role in explaining the source of workplace inequality. That said, the two concepts are not unrelated, and here I turn to the third reason: if we succeed in breaking up the patterns surrounding childbirth than we are likely to make inroads into the patterns of child rearing as well.

As may already be clear, I intend to focus largely, though not exclusively, on empirical work originating in economics and sociology. The gender wage gap has been studied extensively, and although the two disciplines come at the issue slightly differently both have increasingly moved toward empirical analyses involving a bounty of available data sources, some collected by the government while other data comes from particular firms. I want to concentrate on the data because it is so rich and informative, and yet too often ignored in legal analyses of gender inequality. Looking at the data closely may help liberate us from some of the reigning myths regarding women's workforce behavior because women's behavior deviates substantially from what much of neoclassical economic theory predicts. But I also want to emphasize that the persistence of gender inequality is about more than economic interests, and necessarily implicates broader issues of gender roles and power. Improving on the current conditions will thus, as Nancy Fraser has recently argued, require "changing both political economy and culture, so 


\section{Family Leave and the Gender Wage Gap}

as to undo the vicious circle of economic and cultural subordination." 19

This article will proceed in three parts. The first part seeks to understand the nature and persistence of the gender wage gap and explores both the data, and the various theories, that help explain the gap. From there, I will analyze the effects of the FMLA, including two recent surveys commissioned by the government that provide some insight into just how little relief the act actually provides. The third and final part will discuss various ways in which the statute might be amended to further the goal of reducing workplace inequality.

\section{UNDERSTANDING THE GENDER WAGE GAP.}

The most common measure of gender inequality in the workplace is the ratio of women's to men's wages, what is often referred to as the gender wage gap. In 1997, women's salaries averaged between seventy and seventy-six percent of men's salaries, depending on the measure that is used. ${ }^{20}$ These figures represent a substantial improvement in the level of inequality that persisted through much of the 1970s, when the wage gap hovered around sixty percent, although most of the improvement occurred during the 1980s as the pay gap has largely stagnated during the last decade. ${ }^{21}$

The earnings ratio is a wildly popular measure, but the average

19 NANCY FRASER, JUSTICE INTERRUPTUS: CRITICAL REFLECTIONS ON THE "POSTSOCIALIST" CONDITION 28 (1997).

20 See U.S. DePT. OF LABOR, BUREAU OF LABOR StATISTICS, BULlETIN 2340 (April 1998). To provide an example of the disparity based on the measure used, in 1996, the female-to-male ratio for full-time workers measured by hourly wage was $81.2 \%$, for weekly wages the percentage was $75.0 \%$, and the annual ratio was $73.8 \%$. Id. For a detailed discussion of the gender wage gap see Francine D. BlaU, MARIANNE A. FERBER AND ANNE E. WinKLER, THE ECONOMICS OF WOMEN, MEN AND WORK 134-43 (1998).

${ }^{21}$ BLAU ET AL, supra note 20, at 136 (noting that the earnings ratio measured by annual earnings "did not increase between 1990 and 1995" while the weekly earnings ratio has declined since 1993). 


\section{Family Leave and the Gender Wage Gap}

figures can be somewhat misleading in that they mask women's increasing heterogeneity, and as a comparative measure likewise overlook some structural features of the labor market that may explain the decline in the wage gap more than the actual progress of women. ${ }^{22}$ For example, in today's labor market, older women suffer far greater wage disparity than younger women; indeed, women entering the labor market today often begin their careers in salary parity with men, or with minor wage differentials, and wage disparities tend to arise following a number of years of work experience. ${ }^{23}$ It is also worth noting that much of the decrease in the wage gap during the last decade resulted from factors that were only tangentially related to the improving labor market position of women. During the 1980s the wages of lower-income men concentrated in manufacturing jobs fell sharply, particularly when compared to women

${ }^{22}$ A number of other interpretive difficulties can arise. For example, focusing on distributions indicates that greater numbers of women are found at the lowest wage level, while men dominate at the top of the wage scale. See, e.g., Annette Bernhardt, Martina Morris, Mark S. Handcock, Women's Gains or Men's Losses? A Closer Look at the Shrinking Gender Gap in Earnings, 101 AMER. J. OF SOCIOLOGY 302 (1995) (analyzing relative wage distributions as opposed to median earnings). The average figure can also dilute some of the existing inequalities due to racial disparities in the incomes of men. As is well known, black men earn considerably less than white men, and wage differences between black men and women are smaller than among whites, so that including blacks within the averages can mask just how much advantage white men have in the labor market. See DAPHNE SPAin AND SuZANNE M. BiAnChI, BALANCING ACT: MothERHOOD, MARRIAGE \& EMPLOYMENT AMONG AMERICAN WOMEN 131-32 (1997) (discussing racial disparities); David A. Cotter et al., Occupational Gender Segregation and the Earnings Gap: Changes in the 1980s, 24 SOCIAL SCI. RSCH. 439, 441 (1995) ("For minorities, gender differentials in earnings ... are smaller than for whites; however, this is because of the disadvantaged position of minority men and not because of any special privileges for minority women."). Moreover, the average figure typically includes only full-time employees, thus excluding the disproportionately female-dominated and lower-paid parttime workforce.

${ }^{23}$ For example, in 1995 the earnings ratio for workers aged 25-34 was 77.8\%, whereas the ratio for those aged 45-54 was 58.1\%. See BlaU ET AL, supra note 20, at 137. See also ClaUdia Goldin, Understanding THE GENDER GAP 59 (1990) (noting discrpency between experiences of younger and older women); Margaret Mooney Marini \& Pi-Ling Fan, The Gender Gap in Earnings at Career Entry, 62 AMER. SocIOLOGICAL Rvw. 588, 597 (1997) (women in sample earned 84\% of men at career entry). 


\section{Family Leave and the Gender Wage Gap}

in service jobs where salaries improved modestly. ${ }^{24}$ Relatedly, there was a significant increase in the wage growth among college-educated workers, and large numbers of college-educated women entered the workforce during the $1980 \mathrm{~s}^{25}$ These factors contributed to the decreasing gender wage gap, and a significant portion of the decrease resulted at least as much from the receding position of men as from improvements in the labor market conditions of women.

Despite these limitations, the gender wage gap provides a useful metric to understanding current labor market inequalities, as well as how the condition of women has improved, or failed to improve, over time. As impressive as the decrease in wage disparity may be, there remains a substantial gap between the earnings of men and women, at least twentyfive percent or a quarter of one's salary, and it is important to try to understand the source of the persistent wage inequalities in order to understand the role the law might play in reducing the disparity further.

Economists tend to view the wage gap as a product of choices, or preferences, women make regarding their commitment to the labor market. ${ }^{26}$ Many women leave the labor market for a period of time to

${ }^{24}$ See SPAIN \& BIANCHI, supra note 22, 108-110 (discussing effect on men's declining wages and the gender gap).

25 Id. at 116-17 (noting that "women were poised by 1980s to advance in the labor force and the decade turned out to be a phenomenol one in terms of earnings improvement for the well educated."); Chinhui Juhn \& Kevin M. Murphy, Wage Inequality and Family Labor Supply, 15 J. OF LABOR ECON. 72, 78-80 (1997) (documenting that women's employment increased most dramatically at upper income wages).

${ }^{26}$ See, e.g., GARY S. BECKER, A TREATISE ON THE FAMILY 41-42 (1991) ("Wage rates are lower for women at least partly because they invest less than men in market human capital, while the productivity of household time is presumably greater for women partly because they invest more than men in household capital."); see also Solomon William Polachek, Occupational Self-Selection: A Human Capital Approach to Sex Differences in Occupational Structure, 63 REV. OF ECON. \& STATISTICS 60 (1981). Among many legal analysts, this theory is sometimes accepted without argument or empirical support, but simply asserted as true. See Larry Alexander, What Makes 


\section{Family Leave and the Gender Wage Gap}

have and to raise children, and this withdrawal from the paid labor force can adversely affect a woman's career as her skills may deteriorate with time spent away from work, or fail to improve as they would if she stayed in the labor force. The likelihood that a woman may leave the labor force to have and to care for children may affect her career decisions in other ways as well. Women may, for example, choose occupations where continuous experience is less important to the career, or where the benefits offered may compensate for lower salaries. ${ }^{27}$ These career choices may also influence educational choices -- the choice of majors or career paths, which may in turn lead to lower salaries and lower opportunities for career progression. These choices, the argument goes, may help explain the severe labor market segregation that exists in the United States, where it remains rare that women work in a job that is integrated on the basis of gender. ${ }^{28}$

As we will shortly see, the economists' preferred explanations sketched briefly above provide far more theoretical than empirical insight. The extraordinary volume of empirical studies on the gender wage gap demonstrates that women's choices - about careers, education and work histories - offer a limited understanding into the persistent gender differentials that characterize the labor market. One important reason for these findings is that women, as a group, demonstrate great variability in their work patterns. Although women, on average, leave the labor force to bear and care for children more frequently than their male counterparts, many women do not take any such leave, and for the majority of women

Wrongful Discrimination Wrong? Biases, Preferences, Stereotypes and Proxies, 141 U. PA. L. REV. 149, 210 (1992) (asserting that labor market disparities are the product of "differences in job preferences between males and females"); Richard A. Posner, An Economic Analysis of Sex Discrimination Laws, 56 U. CHI. L. REV. 1311, 1315 (1989) (assuming for purposes of analysis that women invest less in human capital because they will likely take time out from the labor market).

${ }^{27}$ See infra text accompanying notes 78-82.

${ }^{28}$ The issue of occupational segregation is discussed in more detail infra section I.B. 


\section{Family Leave and the Gender Wage Gap}

who do, their leave is quite short, too short as it turns out to explain the wage and career penalties that are being exacted. ${ }^{29}$ Rather than women's actual labor market experiences, the better explanation for the failure to break the existing patterns appears to lie with the employer's perceptions of women's attachment to the labor force. This expectation or perception, is generally referred to as statistical discrimination, though as I hope to demonstrate a form of discrimination that ought not to be treated as rational, as it generally is, but instead should more often be treated as unlawful discrimination. These issues will be discussed in more detail below. ${ }^{30}$

\section{A. The Human Capital Explanation.}

The significant decrease in the wage gap that occurred in the 1980 s is often attributed to improvement in women's education and, experience, what are defined as human capital factors, as well as to a reduction in levels of discrimination. ${ }^{31}$ Human capital explanations suggest that gender differences in job placement and advancement arise from differences in productivity acquired through education, labor force

${ }^{29}$ See infra text accompanying notes 83-88.

${ }^{30}$ At this point, I should note that I use the term choice guardedly and here want to bracket the discussion of how we ought to describe the choices women make given their limited opportunities and the effects of social conditioning. This is an issue I take up in section I.B. infra.

31 See Francine D. Blau \& Lawrence M. Kahn, Swimming Upstream: Trends in the Gender Wage Differential in the 1980s, 15 J. OF LABOR ECONOMICs 1, 31 (1997) (finding that an increase in skills, experience and occupational status explained a large portion of the decrease in the gender gap); Linda Datcher Loury, The Gender Earnings Gap Among College Educated Workers, 50 INDUS. \& LABOR REL. RVW. 580, 590-91 (1997) (finding an increase in the market price of women's skills which reflects a decrease in discrimination); Kevin Murphy \& Finis Welch, Industrial Change and the Rising Importance of Skill, at 101-32, in UNEVEN TIDES: RISING INEQUALITY IN AMERICA (S. DANZIGER \& P. GOTTSCHALK, EDS., 1993) (finding growth in market price of women's skills explained decrease in wage gap). 


\section{Family Leave and the Gender Wage Gap}

experience, and job tenure. ${ }^{32}$ This theory, despite its now welldocumented empirical shortcomings, has had unusually powerful explanatory force within law, in large measure because it seems to accord so closely with widely accepted notions of common sense. ${ }^{33}$ From a young age, the importance of education is impressed upon us, and training and work experience are generally relevant to an employer's labor market decisions, in particular to their wage setting functions. ${ }^{34}$ Investing in education and experience are two ways in which we seek to enhance our values on the labor market.

\section{Education, Experience and Training.}

Despite this common sense approach, an impressive volume of empirical studies have firmly established that the human capital theory offers but a partial explanation for the gender wage gap. Indeed, the general consensus is that human capital factors explain at most about one third to one half of the pay differentials between men and women - not an insubstantial amount, but far from a complete explanation either. ${ }^{35}$ The

32 For the classic articulation of this theory see GARY S. BECKER, HUMAN CAPITAL (2d ed. 1981).

${ }^{33}$ See, e.g., Kingsley R. Browne, Sex and Temperament in Modern Society: A Darwinian View of the Glass Ceiling and the Gender Gap, 37 ARIZ.L. REV. 971, 978 (1995); Posner, supra note26; Cass Sunstein, Three Civil Rights Fallacies, 79 CALIF. L. REV. 751, 758-60 (1991); Amy L. Wax, Bargaining in the Shadow of the Market: is There A Future for Egalitarian Marriage? 84 VA. L. REV. 509, 546-48, 602-11 (1998).

${ }^{34}$ Of course, our common sense also tells us that the quality of the investments matters tremendously, hence the importance placed on grades. See McKinley Blackburn \& David Neumark, Omitted-Ability Bias and the Increase in the Return to Schooling, $11 \mathrm{~J}$. OF LABOR ECON. 521 (1993) (demonstrating returns to schooling significant primarily for those who obtain relatively high levels of academic achievement). However, these qualitative issues are very difficult to measure because the necessary data are often lacking.

35 See BlAU ET AL., supra note 20, at 189-90 (finding that education and experience explain only one-third of gap excluding occupational component); GOLDIN, supra note 23, at 105 (canvassing studies ranging from 44-74\%); Marini \& Fan, supra 


\section{Family Leave and the Gender Wage Gap}

reasons for the theory's limited explanatory power are generally twofold.

First, women have sharply narrowed the gaps in education and experience, and have, in fact, narrowed the gap to a far greater extent than is reflected in the wage ratio, which suggests that something other than human capital factors are at work. ${ }^{36}$ This is particularly true with respect to education where by the $1980 \mathrm{~s}$ women matched men's college attendance rates, and by 1990 women constituted 54 percent of the college student body. ${ }^{37}$ Women also substantially narrowed the gap in fields of study, an issue that had long been thought to account for much of the earnings inequality. By 1990, women accounted for 50 percent of the biology and 46.2 percent of the mathematics majors, ${ }^{38}$ and a survey

note 22, at 590 ("In studies based on samples of individuals of diverse ages, at most about half of the gender gap in wages is associated with mean differences in human capital between in the sexes -- and in some studies it is considerably less."); Paul Schumann, Dennis A. Ahlburg \& Christine Brown Mahoney, The Effect of Human Capital and Job Characteristics on Pay, 29 J. OF HUMAN RESOURCES 481, 499 (1994) (finding that human capital and job characteristics together explained $50 \%$ of surveyed sample).

${ }^{36}$ William T. Bielby \& Denise D. Bielby, Cumulative Versus Continuous Disadvantage in an Unstructured Labor Market, at 223-25, in GENDER INEQUALITY AT WORK (Jerry A. Jacobs ed. 1995) (finding wage gap of 25\% for female television writers holding human capital factors constant); June O'Neill \& Solomon Polachek, Why the Gender Gap in Wages Narrowed in the 1980s, 11 J. OF LABOR ECON. 205, 209 (1993) ("the narrowing in the gender gap in earnings in the 1980s to a large extent was caused by a narrowing in the gender gap in experience").

37 See SPAIN \& BIANCHI, supra note 22, at 59. In 1998, 29\% of women aged 25 to 29 had completed college, compared to $26 \%$ of men. See UnITED STATES CENSUS Bureau, EduCATional AtTAinment In THE United States at Table 3 (MAR. 1999). Some of the changes in women's educational attainment are the result of women's greater attendance at community colleges along with substantial numbers of older women returning to school, both of which are likely to offer relatively lower payoffs in the market place.

38 SPAIN \& BIANCHI, supra note 22, at 63. These numbers represent sharp gains from the 1970s when women received $27.8 \%$ of biology and $37.4 \%$ of mathematics degrees. $I d$. There were also significant improvements at the graduate levels: women received $51.0 \%$ of Master's degrees and $35.4 \%$ of Doctorates in biology, and $40.1 \%$ of the 


\section{Family Leave and the Gender Wage Gap}

of 1985 graduates found that after controlling for major, grades and quality of education, even recent female college graduates experienced a 10 to 15 percent wage disadvantage..$^{39}$

In the last two decades, women have likewise reduced the disparities in work experience, especially among more recent entrants to the workforce. For example, in 1998, men aged 25 to 34 had a median tenure of 2.8 years with their current employer whereas for women the median was 2.5 years, and it appears that a significant portion of the decline in the wage gap is attributable to the narrowing of differences in

Master's degrees and $17.8 \%$ of the Doctorates in Mathematics. Id. As the authors explain: "In 1964, approximately one-half of women college students would have had to change majors to achieve the distribution of men's majors. By 1984, only one-third of women would have had to change majors to match men's majors." Id. Barry Gerhart has documented the role college majors play in explaining the wage gap, though in his study two engineering majors (mechanical and electrical) accounted for a large portion of the explanation. See Barry Gerhart, Gender Differences in Current and Starting Salaries: the Role of Performance, College Major, and Job Title, 43 INDUS. \& LABOR REL. RVw. 418, 426 (1990). Despite the advances noted above, it appears that the trend toward greater integration of majors may have stalled. See Jerry A. Jacobs, Gender and Academic Specialties: Trends Among Recipients of College Degrees in the 1980s, 68 SOCIOLOGY OF EDUC. 81, 86 (1995) ("the trend toward lowers legels of segregation across majors that was evident in the early 1980 s slowed or reversed direction in the lates 1980s.”).

39 See Catherine J. Weinberger, Race and Gender Wage Gaps in the Market for Recent College Graduates, 37 InDUS. RELATIONS 67, 82 (1998) ("The analysis shows clearly that among recent college graduates white women . . . black women ... and Asian women all face the same 10 to 15 percent wage disadvantage relative to white men with the same type and quality of college education."). Although field of study is often thought to provide substantial explanatory power, not surprisingly, the primary effect of a college major is to determine in which industry the person is likely to work. Therefore, it is often difficult to know whether the major is tied to wages or whether the observed wages are a product of the industry. See Charles Brown \& Mary Corcoran, Sex-Based Differences in School Content and the Male-Female Wage Gap, 15 J. LABOR ECON. 431, 460 (1997). In this way, field of study is closely related to the issue of occupational segregation and choice, discussed in more detail infra at --. 


\section{Family Leave and the Gender Wage Gap}

experience. $^{40}$

Like education and experience, job training can also enhance one's value on the labor market, especially job training that is general rather than specific to a particular firm, and the human capital theorists suggest that women are likely to invest less in job training because that training has a lower value for women because of the likelihood that they may spend significant time out of the labor market. ${ }^{41}$ There is indeed evidence that women receive less job training than men, though the evidence is not overwhelming, ${ }^{42}$ and often difficult to interpret. For

40 See U.S. DePt. Of LABOR, BUREAU of LABOR StATISTICS, EMPlOYEE

TENURE IN 1998, at Table 1 (1998). The differences were greater with older workers, where men aged 45 to 54 had a medain tenure of 9.4 years compared to women's median of 7.2 years. Id. See also Francine D. Blau, Trends in Well-Being of American Women, 1970-1995, 36 J. OF ECON. LIT. 112, 119 (1998) (noting that "among full-time workers, the gender difference in full-time experience declined from 7.5 years in 1979 to 4.6 years in 1988"); Allison J. Wellington, Changes in The Male/Female Wage Gap, 1976-85, $28 \mathrm{~J}$. HUMAN RESOURCES 393, 395 (1993) (concluding that changes in market experience for women explained significant portion of reduction in wage gap). There is also evidence that early labor market experience is only mildly significant to later wages, as many young employees explore various jobs in their early careers. See Rosella Gardecki \& David Neumark, Order from Chaos? The Effects of Early Labor Market Experiences on Adult Labor Market Outcomes, 51 INDUS. \& LABOR REL. RVW. 299 (1998). The importance of early job attachment appears somewhat more important for women who generally have a greater need to signal their workplace commitment to employers. Id. at 319.

${ }^{41}$ See Anne Beeson Royalty, The Effects of Job Turnover on the Training of Men and Women, 49 INDUS. \& LABOR REL. RVw. 513, 520 (1996) (finding that job turnover rates may explain as much as $25 \%$ of the training differential). Even these results, however, leave three-quarters of the training differential unexplained by job turnover rates.

42 A 1995 Survey conducted by the Bureau of Labor Statistics found that men averaged 48 hours of training during the six months of the survey period, while women averaged 42 hours. See U. S. DePT. Of LABOr, BurEau of LABOR STATISTICS, 1995 SURVEY OF EMPLOYER PROVIDED TRAINING - EMPLOYEE RESUlTS 3 (1996). However, the report concluded that this difference was too small "relative to the precision of estimates" to conclude that the difference was meaningful. Id; see also Jonathan R. Veum, Training Among Young Adults: Who, What Kind, and For How Long? 116 MONTHLY LABOR RVw. 27 (1993) (discussing lower training rates among women). Other surveys indicate that women's investments in training are comparable to men's, though the duration of their training appears to be shorter. See Mark A. Lowenstein \& James R. 


\section{Family Leave and the Gender Wage Gap}

example, the standard neoclassical argument is that the difference in training reflects women's lower investments has less force when the employer provides the training, as is true with most forms of training, unless women are opting out of the training on a voluntary basis, or employers are discriminatorily applying their training opportunities. ${ }^{43}$ It has also been suggested that the difference in training is primarily due to the kind of jobs women occupy, which tend to offer less training opportunities than the jobs of their male counterparts. ${ }^{44}$ As such, it is difficult to know how to interpret the differential training, other than perhaps to suggest that it does not appear to provide strong explanatory power. Reviewing the evidence relating to human capital investments two economists recently concluded, "[I]t is clear that closing the human capital gap between men and women, with regard to skill acquisition, training, and particularly work experience ... will not by itself close the

Speltzer, Delayed Formal On-the-Job Training, 51 InDUS. \& LABOR REL. RVw. 82, 95 n.20 (1997).

${ }^{43}$ A study involving Canadian women provides some evidence to refute the notion that women accumulate less firm-specific human capital than men because, in the study, women tended to suffer greater wage loss following a job displacement than men. See Thomas F. Crossley, Stephen G. Jones, \& Peter Kuhn, Gender Differences in Displacement Cost: Evidence and Implications, 29 J. OF HUMAN RESOURCES 461, 47477 (1994). This finding is inconsistent with the human capital story, which suggests that women invest less in training so that they will not suffer as much of a penalty when they leave a job. Alternatively, employers might provide less training to women because of their perceived shorter work life. See RONALD G. EHRENBERG \& ROBERT S.SMITH, MODERN LABOR ECON. 308 ( $6^{\mathrm{TH}}$ ED. 1997). Another fact that conflicts with the human capital story is that one would expect women to receive a higher wage early in their career when men are devoting more time, and presumably receiving lower wages, in training. See BLAU ET AL., supra note 20, at 181-83. There is, however, no evidence to support this notion.

${ }^{44}$ See John M. Barron, Dan A. Black, \& Mark A. Lowenstein, Gender Differences in Training, Capital and Wages, 28 J. OF HuMAN RESOURCES 343, 361 (1993). Interestingly, training that is firm specific tends to improve women's job tenure much more significantly than it does for men. See Lisa M. Lynch, The Role of Off-the-Job vs. On-the-Job Training for the Mobility of Women Workers, 81 AMER. ECON. RVW. PAPERS \& PROCEEDINGS 151, 155 (1991). 


\section{Family Leave and the Gender Wage Gap}

gender wage gap." 45

A second important limitation to the human capital explanation is that there is now substantial empirical documentation that the characteristics typically treated as human capital factors do not fully explain an employer's wage setting process and therefore do not account for significant portions of wage functions. ${ }^{46}$ Some of the lack of explanatory power is due to the sheer difficulty of measuring individual productivity for which education, experience and training are generally used as rough proxies,${ }^{47}$ while still other measurement issues arise due to

45 Judith Fields \& Edward N. Wolff, Interindustry Wage Differentials and the Gender Wage Gap, 49 INDUS. \& LABOR REL. Rvw. 105, 118-19 (1995). As discussed below, the authors of the study found that women were concentrated in lower paying industries and that this distribution explained about one-third of the wage gap. Id. at 11618.

${ }^{46}$ See, e.g., Barbara Stanek Kilbourne et al, Returns to Skill, Compensating Differentials, and Gender Bias: Effects of Occupational Characteristics on Wages of White Women and Men, 100 AMER. J. OF SOCIOLOGY 689, 704 (1994) (finding experience but not education explained significant portion of wage gap); Linda K. Stroh et al, All the Right Stuff: A Comparison of Female and Male Managers' Career Progression, 77 J. OF APPLIED PSYCH. 251, 255 (1992) ("Education was the only human capital variable that predicted salary progression."); James L. Medoff \& Katherine G. Abraham, Are Those Paid More Really More Productive? The Case of Experience, 16 J. OF HUMAN RESOURCES 186, 215 (1981) (concluding that only "a small fraction of experienceearnings differentials can be explained by experience productivity differentials."); Andrew Weiss, Human Capital vs. Signaling Explanations of Wages, 9 J. OF ECON.

PERSPECTIVES 133, 141 (1995) (finding that "test scores, and measurable learning in secondary school can explain at most one-quarter" of the increased earnings associated with high school degree).

${ }^{47}$ For discussions relating to the difficulty of measuring productivity see EHRENBERG \& SMITH, supra note 44, at 382-83 (discussing difficulty of measuring many qualitative aspects of performance); Hae-shin Hwang, W. Robert Reed \& Carlton Hubbard, Compensating Wage Differentials and Unobserved Productivity, $100 \mathrm{~J}$. OF POL. ECON. 835, 843 (1992) ("[W]e suggest that 30-50 percent of total worker productivity variance remains uncaptured by the usual set of labor market productivity variables - variables such as age, labor market experience, and formal schooling."); Medoff \& Abraham, supra note 46, at 210-15 (questioning the relationship between pay and productivity). 


\section{Family Leave and the Gender Wage Gap}

peculiarities of the labor market that are still not well understood. ${ }^{48}$ The few studies that have been able to measure productivity directly have concluded that the wage gap cannot be attributed to productivity differences between men and women. ${ }^{49}$

\section{The Question of Hours.}

Education, experience and training constitute the characteristics that are typically considered in human capital explanations, but another possible explanation for why men are paid more than women, even for similar jobs, may be tied to their availability to work longer hours, an availability that may have to do with child rearing rather than the circumstances surrounding the fear that women will exit the labor market

${ }^{48}$ For example, contrary to what might be expected under neoclassical models, employers are reluctant to lower wages when faced with slack demand and instead prefer to layoff workers. Additionally, it often appears that employers pay more than is necessary to attract qualified employees. For discussions of these and other issues relating to the particularities of the labor market see ROBERT M. SOLOW, THE LABOR MARKET AS A Social InstituTion (1990); Jeremy I. Bulow \& Lawrence H. Summers, A Theory of Dual Labor Markets with Application to Industrial Policy, Discrimination, and Keynesian Unemployment, 4 J. LAB. ECON. 376 (1986); Andrew Weiss, supra note 46; Janet L. Yellen, Efficiency Wage Models of Unemployment, 74 AMER. ECON. Rvw. 200 (1984). It is also well-established that large employers tend to pay higher wages than smaller employers. See Walter Y. Oi, Employment Relations in Dual Labor Markets ("It's Nice Work If You Can Get It"), 8 J. OF LABOR ECON. S124 (1990) (discussing effect of employer size on wages).

49 An important recent study using data from 1989 found that women were somewhat less productive than men but that "women's wages fall short of men by considerably more than can be explained by their lower marginal productivity." Judith K. Hellerstein, David Neumark \& Kenneth Troske, Wages, Productivity, and Worker Characteristics: Evidence from Plant-Level Production Functions and Wage Equations, 17 J. OF LABOR ECON. 409, 433 (1999). An earlier study that also utilized direct measures of productivity found that women had "comparable productivity" but "much lower wages" than men. See Harry J. Holzer, The Determinants of Employee Productivity \& Earnings, 29 INDUS. RELATIONS 403, 415 (1990). 


\section{Family Leave and the Gender Wage Gap}

when they have children. ${ }^{50}$ Under this theory, women may not be able to work as many hours, put in the necessary overtime for example, or they may be less attentive at work due to concerns about their children, and these differences are reflected in lower wages. This is a complicated and controversial issue on which the data are not likely to provide a convincing explanation because effort levels, or dedication, are the kind of workplace intangibles that are difficult to quantify, and therefore difficult to assess other than through speculation. ${ }^{51}$ However, the data that are available suggest that this explanation fails to demonstrate that the pay differentials relate to productivity differences.

One potential measure of effort or dedication would be hours worked, under the notion that the more dedicated employees work longer hours. This is, of course, an imperfect measure because the most dedicated employees may be the most efficient (saving employers in hourly compensation). ${ }^{52}$ To the extent hours matter, men do spend more time in the labor market than women, but the differences are not particularly significant and do not explain the observed pay differentials. Recent data from the Current Population Survey indicates that in 1997 thirty percent of men and fifteen percent of women usually worked more than 44 hours in a week, while only one in ten men and one in thirty

50 See Paul Weiler, The Wages of Sex: The Uses and Limits of Comparable Worth, 99 HARV. L. REV. 1728, 1780-81 (1986) (arguing that the difference in hours worked between men and women offers significant explanatory power).

51 For an argument that unobserved characteristics, such as motivation, explain a substantial portion of the wage gap see Moon-Kak Kim \& Soloman W. Polachek, Panel Estimates of Male-Female Earnings Functions, 29 J. OF HUMAN RESOURCES 406 (1994). As noted in the text, by its very nature these characteristics are difficult to measure or model and thus not easy to assign any causal role without a substantial element of speculation.

${ }^{52}$ It is not clear that a willingness to work longer hours ought to result in higher hourly wages, where there also exists a significant wage gap. See note 20 supra.

However, employers may be willing to pay higher hourly wages to those employees who are willing to take on longer hours for a variety of reasons, including the perception that these employees are harder workers. 


\section{Family Leave and the Gender Wage Gap}

women worked more than 54 hours a week..$^{53}$ Excessive hours were considerably more likely at the managerial level than in nonsupervisory positions,${ }^{54}$ and on average men worked 44 hours per week while women worked 41 hours. ${ }^{55}$ Interestingly, the wage premium paid for working extended hours was marginally higher for women than men, ${ }^{56}$ suggesting that women can benefit by taking on longer hours, and the data also suggest that women have increased their work hours in recent years more than their male counterparts. ${ }^{57}$

53 See Daniel Hecker, How Hours of Work Affect Occupational Earnings, 121 MONTHLY LABOR RVw. 8, 9 (1998).

${ }^{54}$ At the managerial level, $50 \%$ of men and $30 \%$ of women worked more than 44 hours in a week. Id.

${ }^{55} I d$. at 10. It is easy for lawyers, who work unusually long hours, to overemphasize the importance of long hours, and indeed lawyers have been quick to suggest to me that a disparity in hours was likely to offer a significant explanation. Interestingly among lawyers, the average hours worked for men and women were roughly the same, although a larger percentage of men ( $25 \%$ compared to $18 \%$ of women) worked more than 55 hours a week. Id. at 11-12.

${ }^{56} I d$.

57 Relying on data from the Panel Study of Income Dynamics for the period 197989, Barry Bluestone and Stephen Rose concluded, "As a general rule ... there has been a slight reduction in men's work hours and a large increase in women's hours." Barry Bluestone \& Stephen Rose, Overworked and Underemployed, THE AMER. PROSPECT 58, 64 (Mar.-Apr. 1997). Women also constitute the majority of employees who have taken on second jobs during the last decade. $I d$. at 59 (noting that in 1995, 6.4\% of the workforce reported working second jobs and that "[v]irtually all of this increase has occurred among women, who now represent nearly half of all multiple job holders."). The question whether hours are increasing for workers and the importance of working longer hours is a controversial and hotly debated issue. The common perception is certainly that people are working longer hours to either get ahead or stay even. See, e.g., JULIET B. SCHOR, THE OVERWORKED AMERICAN: THE UNEXPECTED DECLINE OF LEISURE (1993); Louis Uchitelle, At the Desk, Off the Clock and Below Statistical Radar, N. Y. TIMES, July 18, 1999, at Sec. 3-4, p.6. Detailed time-use studies conducted at the University of Maryland, however, show that people are working less than they once did and actually have more free time than they generally believe. See JoHn P. RoBinson, TIME FOR LiFE: THE SURPRISING WAYS AMERICANS USE THEIR TIME (1997). As a result, probably the best we can say is that the data compiled by the government indicate that hours have 
Another aspect of the effort equation on which the data provide some insight is the fact that women generally spend more time on combined market and nonmarket work than men. ${ }^{58}$ This suggests that women may have more overall effort to expend than men, so that even if women have more duties outside of the workplace, there is no particular reason to believe that women would be unable to devote sufficient time or energy to their job. On the contrary, the perception that women do not have comparable time or energy for labor market activities may reflect a pervasive stereotype, one that may hinder women's advancement in the workplace.

\section{Marriage, Children and Housework.}

The above survey demonstrates that the traditional human capital story falls short as a means of explaining the persistence of the wage gap. Although employers generally take education, experience and training into account in making hiring decisions and determining pay scales, they seem

remained stable during the last decade, and there is as yet no conclusive evidence that men are working more than women at a rate that might explain the pay gap.

58 See, e.g., Francine M. DeUtSch, HAlVING IT All: How EQUAlly SHARED PARENTING WORKS 6 (1999) (noting that in three fourths of families that did not share work equally women worked more total hours than their husbands); Joni Hersch, Economics of Housework, in WOMEN AND WORK: A HANDBOOK 83, at 84-85 (Paula J. Dubeck \& Kathryn Borman eds. 1996) (“Although men average more hours than women in paid employment, full-time employed women spend more total time on housework and market work than men do.”). A study of dual earner families based on a 1986-87 national sample found that women worked a total of 68.8 hours a week compared to 63.4 hours for men. See Harriet B. Presser, Employment Schedules Among Dual Earner Spouses and the Division of Household Labor By Gender, 59 AMER. SOCIOLOGICAL Rvw. 348, 353 (1994). These figures did not include childcare and therefore almost certainly underestimated women's hours. Id. 


\section{Family Leave and the Gender Wage Gap}

to take other factors into account as well..$^{59}$ Two such factors that appear to be considered by employers, and valued differentially for men and women, are marriage and children. As has been well documented, for men, marriage is typically rewarded with a wage premium, while for women marriage has either a neutral or modestly negative effect on their wages. ${ }^{60}$ Having children, on the other hand, is generally a negative factor in the labor market for women, though neutral for men. ${ }^{61}$

59 It is also worth noting that occasionally, employers set policies with little concern for their rationality. For example, a study of a large insurance company found that receiving an outstanding performance rating actually had a negative effect on promotion. See Heidi L. Hartman, Internal Labor Markets and Gender: A Case Study of Promotion, at 80, in GENDER IN THE WORKPLACE (Clair Brown and Joseph Pechman eds., 1987). In invalidating a program that denied women their accrued seniority while on leave, the Supreme Court, in an opnion written by Justice Rehnquist, noted that the policy appeared economically unwise in that "inexperienced employees are favored over experienced employees. . . ." Nashville Gas Co. v. Satty, 434 U.S. 136, 143 n.5 (1977).

${ }^{60}$ See, e.g., Marcia Bellos, The Effects of Marital Status \& Wives' Employment on the Salaries of Faculty Men: The (House)Wife Bonus, 6 GENDER \& SOCIETY 609 (1992) (discussing marital bonus for male faculty members); Joni Hersch, Male-Female Differences in Hourly Wages: The Role of Human Capital, Working Conditions, \& Housework, 44 INDUS. \& LABOR REL. RVw. 746, 752 (1991) ("Consistent with other studies, being married is positively related to men's earnings and not significant for women."); Martha S. Hill, The Wage Effects of Marital Status \& Children, 14 J. OF HUMAN RESOURCES 549 (1979) (documenting male wage premium for marriage); Jerry A. Jacobs, Women's Entry Into Mgt.: Trends In Earnings, Authority \& Values Among Salaried Managers, 37 ADMIN. SCIENCE Q. 282, 296 (1992) (finding marital status had negative effect on wages of female managers but positive effect for men); Eng Seng Loh, Productivity Differences and the Marriage Wage Premium for White Males, 31 J. OF HUMAN RESOURCES 566 (1996) (surveying literature on male wage premium). One recent study suggests that the male wage premium declined significantly in the 1980s. See Jeffrey S. Gray, The Fall in Men's Return to Marriage: Declining Productivity or Changing Selection? 32 J. OF HuMAN RESOURCES 481, 491 (1997) (finding that "the return to marriage for men fell by $45 \%$ over the 1980 s.").

${ }^{61}$ Hill, supra note 60, at 558; Sanders Korenman \& David Neumark, Marriage, Motherhood \& Wages, 27 J. OF HuMAN RESOURCES 233 (1992) (finding that marriage did not affect wage rates for women but presence of children did); Jane Waldfogel, supra note 7, at 147 (noting that "[h]aving children had positive or no effects for men, but very strongly negative effects for women ...”). 
These factors - marriage and children - might be related to an employee's productivity, as the difference being married makes to wages could be explained by the contributions a marriage might offer toward the wage earning potential of men and women. Indeed, a number of commentators have suggested that marriage makes men more productive in the workplace, although even among those who adopt this position it is often uncertain how the increase comes about. ${ }^{62}$ One explanation suggests that after marrying, men tend to settle down and become more serious about their work life (or devote less time to housework), which could contribute to increased productivity in the workplace. For men, marriage may also be seen as a proxy for some desirable characteristic, as it may be that better workers are more likely to be married. ${ }^{63}$

The argument that marriage either makes men more productive, or is a useful proxy for some unmeasurable productivity component, fails to offer a convincing explanation upon even a cursory evaluation. The idea that marriage is a helpful proxy for labor market success ignores the high number of marriages that fail, and it would surely be fanciful to think that employers can foresee which marriages were most likely to last. If they could make this determination, then marriage would no longer be the proxy, but the additional characteristic that determines whether the

62 See Lawrence Kenny, The Accumulation of Human Capital During Marriage by Males, 21 ECON. INQUIRY 223 (1983) (suggesting that marriage contributes to men's human capital); Sanders Korenman \& David Neumark, Does Marriage Really Make Men More Productive?, 26 J. OF HUMAN RESOURCES 282 (1991) (suggesting marriage does increase productivity for men).

63 At first blush, it may appear that, if true, this explanation ought also to apply to women, and one recent study found a marriage wage premium related to productivity differences for both men and women. See Hellerstein et al., supra note 49, at 443 ("Workers who have ever been married are paid more than never-married workers, and the wage premium they receive reflects corresponding productivity premium."). It is also possible that the desirable male workers are marrying women who are more likely to help out at home than devote themselves to the workforce. Ultimately, this is an empirical question on which I have seen no data. However, given that highly educated men tend to marry highly educated women - a sign of investment in the labor market - this appears unlikely. See JERRY JACOBS, REVOLVING DOOR 44 (1989) (“[O]n average, highly educated men marry women who are themselves well educated."). 


\section{Family Leave and the Gender Wage Gap}

marriage will succeed would be the key factor for employers to consider. Conceivably, the simple fact of marriage, not the success of that marriage, provides an important signal for an employer regarding future labor market success, but if this were so "marriage" would then be a proxy for some productivity component and it is difficult to understand exactly how the act of marrying provides significant evidence to an employer, particularly independent of the success of that marriage. On the contrary, several recent studies suggest that in many ways marriage may lead to lower productivity for men; for example, married self-employed men earn less than single self-employed men, which belies the notion that something about marriage contributes positively to the workplace for men but not for women, ${ }^{64}$ and married men actually perform a shade more housework than single men. ${ }^{65}$

Nevertheless, while the rationale may not be fully understood or supported by the data, marriage is clearly treated as a positive factor in the workplace for men, whereas for women it proves considerably more ambiguous and is more likely than not seen as a negative attribute. ${ }^{66}$ As

${ }^{64}$ Eng Seng Loh, supra note 60, at 571 (demonstrating that wage premium not reflected among self-employed men); see also Jeffrey S. Gray, supra note 60, at 493-4 (1997) (finding that marriage decreases productivity for men); McKinley Blackburn \& Sanders Korenman, The Declining Marital-Status Earnings Differential, 7 J. OF POPULATION ECON. 249 (1994) (documenting decrease in returns to marriage with years married).

${ }^{65}$ See Chloe E. Bird, supra note 4, at 38 (reporting that married men in survey performed 90 minutes more housework a week than single men); David H. Demo \& Alan C. Acock, Family Diversity and the Division of Domestic Labor, 42 FAMILY RELATIONS 323, 330 (1993) (finding that married men worked approximately 5 hours more per week than unmarried men).

66 There is some evidence that marriage is treated more positively for black women than for white women. See Barbara Kilbourne et al., Effects of Individual, Occupational, and Industrial Characteristics on Earnings: Intersections of Race and Gender, 72 SOCIAL FORCES 1149, 1165 (1994) ("In contrast to the nonsignificant effect of marital status for white women . . black women's earnings significantly increase by about 3\% upon marriage."). The wage premium black women receive upon marriage, however, falls far short of that received by black and white men. See id. (finding a wage premium of $13 \%$ for white men and $9 \%$ for black men.). 


\section{Family Leave and the Gender Wage Gap}

discussed in more detail in the next section, the reason marriage often carries negative connotations for women has to do with an employer's expectation that following marriage, women are likely to leave the workforce for some period of time to have and to care for children. In addition to being married, having children also produces disparate effects on the salaries of men and women, depressing those for women while generally not affecting male salaries. Here the salary differentials seem to be based largely, though not entirely, on the actual experiences of men and women, at least with respect to group averages, as women tend to experience greater absences than men in the workplace when they have young children. ${ }^{67}$ One recent study estimated that for women each additional child under six years of age increased the probability of absence from work by more than twenty-five percent although the actual loss work time remains relatively low. ${ }^{68}$ In contrast, having children at home tends not to affect men's absences. ${ }^{69}$

${ }^{67}$ It is important to emphasize that the wage differentials are not entirely steeped in actual characteristics that are relevant to the workplace. Sociologist Jane Waldfogel recent comprehensive study on the effect of children on women's wages concluded: "Even after controlling for human capital, unobserved heterogeneity, and part-time job status . . there is still a 4 percent penalty for having one child and a nearly 12 percent penalty for having two or more children." Jane Waldfogel, The Effect of Children on Women's Wages, 62 AMER. SOCIOLOGICAL Rvw. 209, 215 (1997).

68 Jessica Primoff Vistnes, Gender Differences in Days Lost from Work Due to Illness, 50 Indus. \& LABOR RELATIONS Rvw. 304, 319 (1997); see also J.P.Leigh, Sex Differences in Absenteeism, 22 INDUS. REL. 349 (1983) (presence of children under six increased absences for women but not for men). Recent data from the Bureau of Labor Statistics indicates that women aged 16 and over missed work at a rate that was nearly twice as high as men, though they missed less than $3.0 \%$ of their work time on average. See U.S. DEPT. OF LABOR, EMPLOYMENT AND EARNINGS Table 44, at 219 (1998) (women had a loss worktime rate of $2.8 \%$ compared to the male rate of $1.5 \%$ ). The Bureau of Labor Statistics measured loss work for the following reasons: own illness, injury, or medical problems, child-care problems, other family or personal obligations, civic or military duty, and maternity or paternity leave.

${ }^{69}$ Vistnes, supra note 68, at 316. There was, however, an increase, though not statistically significant, of missed days from work for men with children in day care, which was presumably a sign that the man's wife worked and thus was less able to devote time to caring for the children. $I d$. at 318 . Women with children who opt for part-time work also 


\section{Family Leave and the Gender Wage Gap}

It has likewise been demonstrated that time spent on housework significantly depresses wages. Professors Joni Hersch and Leslie Stratton recently documented that, for women, time spent on housework has a strong negative effect on wages and may explain as much as ten percent of the gender wage gap. ${ }^{70}$ Though less substantial, the effect on men's wages was likewise statistically significant. ${ }^{71}$ Interestingly, the authors found no significant effect on the wages of women who performed ten hours or less of housework a week, an amount that is generally on par with the level of most men. ${ }^{72}$ Not surprisingly, women in the study engaged in approximately three times as much housework as men, an estimate that is generally consistent with most previous studies, though higher than some. ${ }^{73}$ These disparities persist even in dual earner couples

suffer a significant wage penalty, as is true for those who work part-time more generally. See Waldfogel, supra note 67, at 215 (finding a wage penalty of over 10 percent).

70 See Joni Hersch \& Leslie S. Stratton, Housework, Fixed Effects and Wages of Married Women, 32 J. OF HuMAn RESOURCES 285, 300-01 (1997). This study was based on a sample of more than 3500 individuals over a period ranging from 1979-87. Id. at 289-90.

${ }^{71} I d$. at 301 . The authors were puzzled by the gender specific wage penalty for housework, and suggested the disparity may be a sign that employers discriminate against women, but not men who devote substantial time to housework. Id. at 304. This observation supports the role of statistical discrimination discussed more fully below.

${ }^{72} I d$. at 294.

${ }^{73} I d$. at 289-90. In the sample, women averaged 19.2 hours of housework a week while men averaged 6.77 hours. Id. In contrast to these figures, Kathleen Hall Jamieson cites numerous studies indicating that men perform on average about $20 \%$ of household tasks and devote one-third or less of time to children compared to mothers. See KathleEn Hall JamiEson, Beyond THE Double Bind 62 (1995); see also Demo \& Acock, supra note 65, at 329 (finding that mothers spend between 40-44 hours per week on household labor while husbands or partners averaged 13). For a discussion of the studies on housework see Katharine Silbaugh, Turning Labor into Love: Housework and the Law, 91 NORTHWESTERN U. L. REV . 1, 8-10 (1996). There is some evidence that the gap in hours is decreasing, primarily as a result of women decreasing the number of hours they devote to housework. See Blau, supra note 40, at 151 . The disparities also vary some by race as black men tend to have more egalitarian views regarding gender norms and housework. See Terri I. Orbach \& Sandra L. Eyster, Division of Household Labor 


\section{Family Leave and the Gender Wage Gap}

where women still perform approximately twice as much housework as their spouses. ${ }^{74} \quad$ Thus, it seems clear that marriage and children negatively affect women's wages and career paths, and that the penalties exacted are not all directly tied to actual differences in productivity but are more likely steeped in perceptions and expectations about women's workforce participation.

\section{Women's Labor Force Attachment.}

As just noted, the greater time that women spend on their children and on housework explains a portion of the gender wage gap. Yet, just as was true with the traditional human capital factors, the observed differences do not fully explain the gap, and something else appears to be responsible for the persistence of gender labor market inequalities. That missing factor, which may also be implicit in the marriage and child penalties, is generally thought to be women's labor market behavior. In particular, women's supposed tendency to exit the labor market for periods of time to have and to care for children, as well as their choices about careers, is generally said to explain why women end up in different jobs than men or are paid significantly less than their male counterparts. For example, given their disproportionate responsibility for child rearing, women may choose jobs that offer greater flexibility or that require comparatively less work effort, as Gary Becker hypothesized many years ago. $^{75}$ Similarly, women may be trading lower wages for higher

Among Black and White Couples, 76 SOCIAL FORCES 301, 325 (1997)

74 See Sampson Lee Blair \& Michael P. Johnson, Wives' Perceptions of the Fairness of the Division of Household Labor: The Intersection of Housework and Ideology, 54 J. OF MARRIAGE \& THE FAMILY 570, 575 (1992) (finding that nonemployed wives performed four times as much housework as their employed spouses while employed women did twice as much); Presser, supra note 58, at 353 (in sample women in dualearner families worked twice as many hours in the home as men).

75 See BECKER, supra note 32; Gary Becker, A Theory of the Allocation of Time, 75 ECON. J. 493 (1965). Becker's argument is succinctly set forth in Gary S. Becker, Human Capital, Effort, and the Sexual Division of Labor, 3 J. OF LABOR ECONOMICS S33 (1985). For additional discussions along these lines see Solomon William Polachek, 
workplace benefits because they may have more to gain from generous health insurance or leave policies. ${ }^{74}$

Again, like the closely related human capital theory, these ideas offer more intuitive than explanatory power. A number of recent studies have demonstrated that the sex composition of the particular job does not explain women's employment behavior, which suggests that women are not choosing jobs or occupations that necessarily facilitate more flexible work schedules. ${ }^{75}$ If the theory were true, if for example women were choosing jobs that facilitated child rearing, one would expect to find women concentrated in occupations that require less effort or for which on the job training was comparatively less important because women would then have more time to spend on their home life and would also have less invested in the workplace, making it less costly to move in and out of the workforce. However, based on his exhaustive analysis of data from North Carolina, Professor Donald Tomaskovic-Devey recently concluded, "It is striking that neither being married and having young children nor working part-time affects whether women or men choose sexsegregated employment." ${ }^{176}$ Mary Becker likewise observed some years ago: "Women with less continuous employment experience are about as

supra note -- (suggesting that women's labor force attachment accounts for occupational differences); Posner, supra note 26, at 1330 (assuming that women are attracted to jobs requiring less human capital).

74 See, e.g., Randall K. Filer, Male-Female Wage Differences: The Importance of Compensating Differentials, 38 INDUS. \& LABOR REL. RVW. 426 (1985)

(hypothesizing that women trade benefits for other desirable workplace characteristics); Paul Weiler, supra note 50, at 1778 (arguing that working conditions can help explain wage gap).

75 See, e.g., Sonalde Desai \& Linda J. Waite, Women's Employment During Pregnancy and After the First Birth: Occupational Characteristics and Work Commitment, 56 AMER. SOCIOLOGICAL RVw. 551, 563 (1991) ("[W]e find no effect of the sex composition of the occupation, which could ... signify that the sex composition of the occupation has no influence on the employment of pregnant women and new mothers.").

${ }^{76}$ Donald Tomaskovic-DeVey, Gender \& RaCial INEQUality AT Work 50 (1993). 


\section{Family Leave and the Gender Wage Gap}

likely to be in male fields as women with more continuous employment experience, and the depreciation rates associated with temporary withdrawal from the wage-labor market are not significantly higher for male jobs than for female jobs." ${ }^{77}$

Relatedly, women tend to rank income as highly in importance among job characteristics as men, ${ }^{78}$ and the current data do not support the theory that women are trading lower wages for higher benefits. ${ }^{79}$ As

77 Mary E. Becker, Barriers Facing Women in the Wage-Labor Market and the Need for Additional Remedies: A Reply to Fischel and Lazear, 53 U. CHI. L. REV. 934, 934-35 (1986). See also Paula England, The Failure of Human Capital Theory to Explain Occupational Sex Segregation, 17 J. OF HuMAN RESOURCES 358, 369 (1982) (documenting that "women with continuous employment histories are no less apt than other women to be in predominantly female occupations.")

78 See Jerry A. Jacobs \& Ronnie Steinberg, Further Evidence on Compensating Differentials and the Gender Gap in Wages, at 102, in GENDER INEQUALITY AT WORK (Jerry A. Jacobs ed. 1995) ("Survey data suggest that working women rank income as high as men do on a list of factors for choosing a job."); Margaret Mooney Marini et al., Gender and Job Values, 69 SociolOGY OF EDUCATION 49 (1996) (finding that young men and women valued rewards of work similarly). A study involving business majors at the University of Illinois found that although men and women both valued salary highly, men seemed to place more weight on salary, while for women career advancement was slightly more important than salary. See Francine D. Blau \& Marianne A. Ferber, Career Plans and Expectations of Young Women and Men, 26 J. OF HUMAN RESOURCES 581, 590 (1991) ("The same three characteristics are rated highest by both groups . . . salary, opportunity for advancement, and intellectual challenge, though men do opt more often for the first two, women for the third.").

${ }^{79}$ See ToMASKOVIC-DEVEY, supra note 76, at 51 ("Women are not selecting typically female jobs to trade higher starting wages for lower wage depreciation when they leave the labor force to have and to care for children."); Sarah Beth Estes \& Jennifer L. Glass, Job Changes Following Childbirth: Are Women Trading Compensation for Family-Responsive Work Conditions?, 23 WORK \& OCCUPATIONS 405, 424 (1996) ("[T]he quantitative analysis yields little evidence that accommodations are being substituted for compensation in the job mobility of new mothers."); Joni Hersch \& Shelley White-Means, Employer-Sponsored Health and Pension Benefits and the Gender/Race Wage Gap, 74 SoCIAL SCI. Q. 851, 865 (1993) (finding that increased benefits do not explain gender wage gap as women "still face a large compensation disadvantage relative to white men."); Joni Hersch, Male-Female Differences in Hourly Wages: The Role of Human Capital, Working Conditions, and Housework, 44 INDUS. \& LABOR REL. RVW. 


\section{Family Leave and the Gender Wage Gap}

a group, women hold jobs that offer less generous benefits than those held by men. ${ }^{80}$ Nor does it appear that the wage gap can be explained by the fact that women choose less strenuous or dangerous jobs, or that they demonstrate a preference for easier jobs. ${ }^{81}$ Although women tend to work in jobs that have better safety records, the data increasingly demonstrate that there is no wage premium for dangerous or undesirable jobs. ${ }^{82}$

746, 757 (1991) (rejecting theory that women are choosing lower paying jobs because of compensating factors because "[i]f women choose lower paying jobs because such jobs provide non-wage compensation, such as pleasant working conditions, we would expect to explain more of the wage gap by controlling for attributes of jobs.").

80 See Joyce P. JACOBSEN, The ECONOMICS OF GENDER 55 (1994) ("It is clear from surveys that women generally have fewer fringe benefits . . . available to them in terms of total monetary value, partly because more women work part-time and partly because the value of some fringe benefits is directly tied to earnings."); William E. Even \& David A. Macpherson, Gender Differences in Pension, 29 J. OF HuMAn ResourCes 555, 555-56 (1994) ("In the United States, 55 percent of male employees were enrolled in a private pension plan in 1988, while only 45 percent of female employees were."); Christine A. Littleton, Does It Still Make Sense to Talk About 'Women'? 1 UCLA WOMEN's L.J. 15,24-25 (1991) (discussing disparity of benefits between men and women).

81 A comprehensive study involving New York state data found that although men worked in jobs with greater extreme working conditions, those conditions did not explain the gender wage gap. In fact the opposite was true as "workers suffer a wage penalty for working in unattractive jobs." Jerry A. Jacobs \& Ronnie Steinberg, supra note 78, at 11314. See also Kilbourne et al., supra note 46, at 704 (finding no support for notion that men are in less desirable or more dangerous jobs as explanation for wage gap).

${ }^{82}$ Two facts illustrate this point: union members receive higher wages and experience lower fatality rates than nonunion members, and wages tend to increase with education while injury rates decrease. For a comprehensive recent discussion of the issue see Peter Dorman and Paul Hagstrom, Wage Compensation for Dangerous Work Revisited, 52 INDUS. \& LABOR REL. RVw. 116 (1998). One of the difficulties with measuring wage premiums for dangerous work is that it is extremely difficult to capture the full costs employees face, including the psychic costs such as pain and suffering they may experience by working in dangerous jobs. See Thomas O. MCGARITY \& SidnEY A. SHAPIRO, WORKERS AT RISK: THE FAILED PROMISE OF THE OCCUPATIONAL SAFETY \& HEALTH ADMIN. 19 (1993). As such, studies tend to underestimate the costs of the jobs and therefore overstate the extent wages may compensate employees for dangerous work conditions. 
Some of these findings may run counter to our common perceptions, although they appear more sensible when we look closely at women's actual labor force behavior, which tends to be far more consistent than is often assumed. For women the most common reason to leave the workforce is to have a child ${ }^{83}$ Yet, following childbirth, the majority of women return to work within six months, and between 40 and 65 percent return within three months. ${ }^{84}$ Reviewing data from the 1990 Child Care Survey, Sandra Hofferth found that 83 percent of those mothers who worked during pregnancy returned to work within one year. ${ }^{85}$ In general, most women return to work in some fashion - as of 1992, nearly eighty percent of women with school age children were working, ${ }^{86}$ and women with children were actually more likely to be in the

${ }^{83}$ See Joyce P. Jacobsen \& Laurence M. Levin, Effects of Intermittent Labor Force Attachment on Women's Earnings, 118 MONTHLY LABOR RVW. 14, 16 (1995) (noting that $85 \%$ of sampled women who left the labor force did so for family reasons); Audrey Light \& Manuelita Ureta, Early-Career Work Experience and Gender Wage Differentials, 13 J. OF LABOR ECON. 121, 142 (1995) (largest group of women left for personal reasons).

${ }^{84}$ See Sonalde Desai \& Linda J. Waite, supra note 75, 558 ("About 43 percent of the new mothers in our sample had returned to work within three months of the birth of their first child, and 69\% had returned to work within 12 months."); Jutta M. Joesch, Children and the Timing of Women's Paid Work After Childbirth: A Further Specification of the Relationship, 56 J. OF MARRIAGE \& THE FAMILY 429, 437 (1994) (finding that of the women surveyed 20\% were out of work for 1 month or less and 53\% returned within six months); Jacob A. Klerman \& Arleen Leibowitz, The Work-

Employment Distinction Among New Mothers, 29 J. OF HuMAN ReSOURCES 277, 296 (1994) ("Today, about half of all women are back at work by the time their child is four months old.").

${ }^{85}$ Sandra L. Hofferth, Effects of Public Private Policies on Working After Childbirth, 23 WORK \& OCCUPATIONS 378, 388 (1996).

${ }^{86}$ These figures are from the Bureau of Labor Statistics and are reported in Howard Hayghe \& Suzanne Bianchi, Married Mothers Work Patterns: The Job-Family Compromise, 118 MONTHLY LABOR Rvw. 6 (1994) (78\% of women with school-age children working in 1992). 


\section{Family Leave and the Gender Wage Gap}

workforce than those without. ${ }^{87}$ Even women with very young children have high participation rates; more than sixty percent of women with children under two are working. ${ }^{88}$

The figures discussed above include those working part-time, ${ }^{89}$ a category that is typically defined as those working fewer than thirty-five hours. Approximately one quarter of working women with children work part-time, ${ }^{90}$ and it is been estimated that fewer than 20 percent of women older than twenty-five work part-time..$^{91}$ Perhaps of more significance,

87 Professor Julia Kirk Blackwelder indicates that as of $1989,58.4 \%$ of women with children under 6 were in the workforce, $73.2 \%$ of women with children between 6-18, and $50.5 \%$ of women without children. See JULIA KIRK BLACKWELDER, NOW HIRING: THE FEMINIZATION OF WORK IN THE UNITED STATES, 1900-95, at 195 (1997).

88 See U. S. DEPT. OF LABOR, BUREAU OF LABOR STATISTICS, EMPLOYMENT CHARACTERISTICS OF FAMILIES, Table 6 (1999). By all accounts, women as a group have greatly increased their attachment to the labor force. Kathryn Shaw, for example, notes that the percentage of female workers defined as having a persistent labor force attachment nearly doubled between the 1970s and the late 1980s. See Kathryn Shaw, The Persistence of Female Labor Supply, 29 J. OF HuMAN RESOURCES 348, 360 (1991).

${ }^{89}$ For a recent discussion of part-time work as it affects women see Ann Bookman, Flexibility at What Price? The Costs of Part-Time Work for Women Workers, 52WASH. \& LEE L. REV. 799 (1995).

90 In 1998, 26.2\% of women with children who worked were working part-time, as measured by fewer than 35 hours a week. See U. S. DEPT. OF LABOR, supra note 2, at Table 5.

${ }^{91}$ See Edward J. McCaffery, Institutional Barriers to Women in the Workplace: Equality of the Right Sort, 6 UCLA WOMEN'S L.J. 289, 298 (1996). McCaffery reports that teenage women and those over 55 are the most likely to work part-time, though the least likely to have children. Id. A survey of young workers based on 1993 data found that $16 \%$ of female workers, and $4 \%$ of male workers worked fewer than 35 hours a week. See Marianne A. Ferber \& Jane Waldfogel, The Long-Term Consequences of

Nontraditional Employment, 121 MonTHLY LABOR Rvw. 3, 5 (1998). Blau and her coauthors suggest that as many as $27 \%$ of employed women worked less than 35 hours per week in 1995. See BLAU ET AL, supra note 20, at 319. Although there appears to be a widespread sense that part-time work is increasing, economist Henry Farber recently concluded that there is "no evidence of a shift to part-time employment," and that the percentage of part-time jobs among newly created jobs was roughly stable. See Henry S. 


\section{Family Leave and the Gender Wage Gap}

those who worked full-time prior to having a child, tended to return to full-time work after their leave; indeed, it appears relatively rare that women (or men) move from full to part-time work. In a recent comprehensive survey of full and part-time workers, Professor Rebecca Blank found that eighty-six percent of women who worked full-time in one year, worked full-time the following year. ${ }^{92}$ Part-time workers were less stable, as twenty percent moved to full-time work and fourteen percent left the labor force altogether. ${ }^{93}$ These figures suggest that it is far more common for women to move from part-time to full-time work than vice versa, and that past labor market experience is crucially important to determining current labor market location..$^{94}$ In other words, women with a continuous labor force attachment prior to childbirth tend to return to that pattern within six months of the birth of the child..$^{95}$

The timing of the workforce disruption, however, can play an

Farber, Job Creation in the United States: Good Jobs or Bad? Working Paper, Indus. Relations Sec., Princeton Univ., July 1997, at 25-28.

92 See Rebecca M. Blank, Labor Market Dynamics and Part-Time Work, in RESEARCH IN LABOR ECONOMICS 9 (Solomon W. Polacheck, ed. 1998). Blank's study, one of the most comprehensive to date on part-time work, analyzed fourteen years of data for men and women employed between 1976 and 1989.

93 Id. at 11

94 Id. at 23 ("[P]ast labor market histories are crucially important in determining current labor market location for adult women."). It appears that the experience that provides the least predictability is past part-time work, since part-time work can be a transitional stage full-time work or to leaving the labor market. Id.

95 See Goldin, supra note 23, at 32 ("Women who are in the labor force tend to remain in for long periods of time, while those out of the labor force tend to remain out."); Hofferth, supra note 85, at 391 ("Working during pregnancy is highly related to working soon after birth."); Joesch, supra note 84, at 436 (finding that the strongest indicator is work status prior to birth); David Shapiro \& Frank L. Mott, Long-Term Employment and Earnings of Women in Relation to Employment Behavior Surrounding First Birth, $29 \mathrm{~J}$. OF HuMAN RESOURCES, 248, 272 (1994) ("This paper has shown that among the [sample] women, employment behavior surrounding the first birth tends to be a significant independent predictor of lifetime work experience."). 
important role with respect to wages. As the authors of a recent study on leave patterns explain, "The general pattern ... is that the gender wage gap increases with experience over the first 10 years or so of the career and then narrows appreciably." ${ }^{96}$ Women who are able to delay childbirth for the first part of their career, are likely to be sufficiently well established so as not to pay such a high penalty when they do have children, though the delay may increase the chances of not having children at all. That said, this does not mean that the differentials are related to productivity differences; indeed, the discussion above suggests they are not. Rather, it appears that the most significant factor underlying the wage disparities is that "men receive a larger return to their work efforts than do women." ${ }^{197}$ This finding suggests that women are penalized not just for their actual labor force disruptions but also based on other factors, including the employer's perception that women are likely to leave the workforce to have children, and for the perceived costs of that anticipated work change, an issue that will be discussed in more detail under the topic of statistical discrimination.

Yet, based on the data reviewed above, it would be a mistake for an employer to assume that women are likely to exit the labor force for significant periods of time after they have a child, where significant is defined as more than four to six months. ${ }^{98}$ At the same time, it is true that

${ }^{96}$ Light \& Ureta, supra note 83, at 142 . There are obviously exceptions to this general pattern. For example, a study of lawyers found that among men and women who graduated from the same law school at the same time women earned about $7 \%$ less than men initially but after 15 years they earned $40 \%$ less. See Robert Wood, Mary E. Corcoran \& Paul N. Courant, Pay Differences Among the Highly Paid: The Male-Female Earnings Gap in Lawyers' Salaries, 11 J. OF LABOR ECON. 417 (1993).

97 Light \& Ureta, supra note 83, at 144.

98 This is especially true among more recent entrants into the workforce. Based on a comprehensive analysis of longitudinal surveys, two economists have concluded, "Assuming that the trends revealed here have been sustained, we can conclude that employers would be completely unjustified in statistically discriminating against young women because of their belief that they are more prone to job separation than their male counterparts." Audrey Light \& Manuelita Ureta, Panel Estimates of Male and Female Job Turnover Behavior: Can Female Nonquitters Be Identified, 10 J. OF LABOR ECON. 


\section{Family Leave and the Gender Wage Gap}

the patterns for women differ significantly from those of men, and it is these differences employers may be taking into account in their employment decisions, and which likely contribute to (but do not fully explain) the persistence of the wage gap. ${ }^{99}$ For example, two-thirds of those who work part-time are women, ${ }^{100}$ and for men, the most common reason for leaving work for a sustained period of time tends to be to return to school, while for women the most common reason is "personal", a term that includes leaving the workforce to have children. ${ }^{101}$

The more difficult question, one I discuss below, is whether these group averages provide a reasonable basis for an employer's decisions, particularly when we consider that the women who are penalized the most by the use of group averages are those women who do not follow the expected pattern - either those women who return to work earlier than expected or those who do not have children but are nevertheless disadvantaged because it is presumed that at some point in their career they will. ${ }^{103}$ It may also be the case that women are simply choosing

$$
156,179 \text { (1992). }
$$

99 See GolDIN, supra note 23, at 213 ("As long as women bear a disproportionate burden in raising children, the labor market will reflect these differences.").

100 Blank, supra note 92, at 2 and Table 1; U.S. DEPT. OF LABOR, BUREAU OF LABOR STATISTICS,, EMPLOYMENT AND EARNINGS 172, Table 8 (Jan. 1995) (women constitute $67.3 \%$ of part-time workers, and $68.9 \%$ of those defined as voluntary part-time workers).

101 See Light \& Ureta, supra note 83, at 128-29 (42\% of men who left the workforce did so to return to school, while $37 \%$ of women left for personal reasons.). There are, however, studies suggesting vastly different reasons for quitting. For example, in her book, Joyce Jacobsen discusses a survey which found that $73 \%$ of the women surveyed quit to work for other companies, and only $7 \%$ quit to care for their children fulltime. See JACOBSEN, supra note 80, at 146. Moreover, as discussed in the next section, the decision to leave the workforce when they have children is strongly influenced by both gender norms and the effect of discrimination on opportunities and work experiences.

103 A study tracing managers who had been relocated as part of a promotional opportunity found that wage differentials persisted even when the male and female managers were nearly identically situated. The authors argued: "[W]ith a sample such as 
different jobs based on their own preferences, which may differ from men's, an issue discussed in the next section.

\section{B. The Issue of Choice.}

The human capital theory explains a portion of the wage gap, which means that women still trail men to some degree in their investments in education, work experience, and training. We also saw that women tend to work fewer hours and miss more work than men, though neither factor appears to substantially explain the issue of gender wage inequality. ${ }^{104}$ In addition, the most marked characteristic of the labor market is the extreme sex segregation across occupations and jobs, a fact that likewise appears to explain a significant portion of the pay gap, although how much, and how the data ought to be interpreted, remain hotly contested issues. ${ }^{105}$ Based on a common index of segregation, as of

the present one, it is legitimate to question why there should be any sex differences in career progression at all. The female managers in this study had followed the traditional male model of career advancement. They had achieved high levels of education and had stayed in the work force. Many of them were less encumbered by family than were the men. Those with families were often the primary wage earners, had relocated their families for their careers, and had not withdrawn from opportunities to relocate. Yet, doing all this had not been enough. Following the traditional male career model had not entirely eliminated the discrimination against them." Stroh et al., supra note 46, at 257.

104 It is also worth noting that there is no indication that the loss work time, which totals less than $3 \%$ of hours worked, is significant enough to adversely affect a worker's productivity to the extent employers might be warranted in taking it into account.

105 See, e.g., BLAU ET AL., supra note 20, at 196 (noting that occupational categories account fors about $8 \%$ of pay gap with more detailed occupational categories raising the level to 14-23\%); William J. Carrington \& Kenneth R. Troske, Gender Segregation in Small Firms, 30 J. OF HUMAN RESOURCES 503, 523 (1995) (finding significant gender segregation across small firms); Michael P. Kidd and Michael Shannon, Does the Level of Occupational Aggregation Affect Estimates of the Gender Wage Gap?, 49 INDUS. \& LABOR REL. Rvw. 317, 326 (1997) (finding that broad occupational categories underestimates gender wage differential); Trond Peterson \& Laurie A. Morgan, Separate and Unequal: Occupation-Establishment Sex Segregation and the Gender Wage Gap, 101 AMER. J. OF SociologY 329, 344 (1995) (based on data from the 1970s and early 1980s finds that occupational segregation explained more than $80 \%$ of the wage 


\section{Family Leave and the Gender Wage Gap}

1990, about half of the women in the labor force would have to switch occupations to achieve equal representation among occupations. ${ }^{106}$ Focusing on occupations likely understates the prevailing level of segregation as there is strong evidence that segregation is even more extreme at the job, rather than occupation, level, and it is still rare that men and women work in gender integrated jobs. ${ }^{107}$ It has also been widely documented that female-dominated jobs pay substantially less than those occupied principally by men, ${ }^{108}$ and we know that women tend to

gap).

106 SPAIN \& BIANCHI, supra note 22, at 94; Blau, supra note 40, at 132 (placing the index at 53 in 1990); David A. Cotter et al.,supra note 22, at 445 ("over half of women would have to change their jobs before their occupational distribution would match men's").

107 See Erica L. Groshen, The Structure of the Female/Male Wage Differential: Is it Who You Are, What You Do, or Where You Work?, 26 J. OF HUMAN RESOURCES 457,462 (1991) (noting that working in an integrated jobs is "fare more unusual" than working in an integrated occupation); Paul L. Schumann, Dennis A. Ahlburg \& Christine Brown Mahoney, The Effects of Human Capital and Job Characteristics on Pay, 29 J. OF HUMAN RESOURCES. 481, 498 (1994) (finding that women were assigned to lower graded jobs than men and that gender played a significant role in assignments); Donald Tomaksovic-Devey, Sex Composition and Gendered Earnings Inequality, at 38, in GENDER INEQUALITY AT WORK (Jerry A. Jacobs ed., 1995) (concluding that gender job segregation explains twice as much of the wage gap than occupational segregation).

Segregation at the job level can be seen on law faculties where there exists a high degree of sex segregation in teaching assignments. See Deborah Merritt Jones \& Barbara F. Reskin, Sex, Race and Credentials: The Truth About Affirmative Action in Law Faculty Hiring, 97 COLUM. L. REV. 199, 267 (1997) (noting that "men and women teach on the same law faculties today, but they are often hired to teach different courses").

108 See SPAIN \& BIANCHI, supra note 22, at 123 (noting that "[o]n average . . . female-dominated occupations pay less well than male-dominated ones."); Blau, supra note 40, at 127 ("Considerable research suggests that predominantly female occupations pay less, even controlling for measured personal characteristics of workers and a variety of characteristics of occupations and industries."); Paula England et al., The Effect of Sex Composition of Jobs on Starting Wages In an Organization: Findings from the NLSY, 33 DEMOGRAPHY 511, 520 (1996) ("These findings add to the cumulating evidence that those who work in female-dominated jobs pay a wage penalty -- that employers assign them lower wages than if the job had a larger proportion of men working in it."); Fields \& Wolff, supra note 45, at 118 (finding women's concentration in lower paying industries 
be primarily responsible for child rearing, and as discussed in more detail below, they also take greater leave at the birth of their children than do men and suffer financially because of their leaves. ${ }^{109}$ As such, the data indicate that men and women tend to perform different jobs both in and out of the workplace.

Given these facts, a question naturally arises as to how we should evaluate this part of the story. One version might view these facts as the product of social forces, including discrimination, that limit the opportunities of women in a number of complicated ways. Contrarily, we may also view these results as the product of choice emanating from autonomous individuals choosing their life paths, a view that is common within economic models and increasingly common among some female legal scholars. ${ }^{110}$ Within this perspective, the fact that women occupy different jobs may appear to be the result of personal preferences, and, therefore, not a proper cause for societal concern. In my judgment, this view offers a highly problematic way of looking at the world, one that is far too simplistic to capture the complexities and nuances of choice and preference, complexities that confound easy attribution and that all too

explains about one-third of wage gap). A recent study seeking to determine whether there were differences between black and white women in the structure of gender equality found no clear pattern. Black and white women both suffered similar sharp wage penalties when the occupation was dominated by women, but black women received a small wage premium for being married, while white women did not. See Barbara Kilbourne, Paula England, Kurt Beron, Effects of Individual, Occupational and Industrial Characteristics on Earnings: Intersections of Race and Gender, 72 SOCIAL FORCES 1149 (1994).

109 The issue of leave taking is discussed infra section I.D.

110 See, e.g., Kathryn Abrams, Ideology and Women's Choices, 24 GA. L. REV. 761 (1990) (critiquing what she defines as ideological determination arguments); Anne M. Coughlin, Excusing Women, 82 CALIF. L. REV. 1 (1994); Carlin Meyer, Sex, Sin, and Women's Liberation: Against Porn-Suppression, 72 TEX. L. REV. 1097 (1994); Nadine Strossen, The Tensions Between Regulating Workplace Harassment and the First Amendment: No Trump, 71 CHI.-KENT L. REV. 701 (1995).. 


\section{Family Leave and the Gender Wage Gap}

many economic models fail to acknowledge. ${ }^{111}$ I will thus argue that it is highly naive to treat the labor market as an unadulterated product of rational utility maximizing, at least in a manner that ought to be treated as unproblematic.

Economic models typically consider observed labor market characteristics as resulting from individual preferences - preferences that are treated as exogenous and not worthy of governmental concern. ${ }^{112}$ While the data provide only weak support for the notion that the existing conditions are the product of preferences at all, the economists' assumption of autonomous preferences has been severely criticized from many different perspectives. One analytical difficulty arises in determining whether women's occupational choices, or their human capital investments, are a product of actual preferences, or a response to labor market opportunities, what has been aptly labeled the "chicken or the egg" problem. ${ }^{113}$ After all, and keeping with the economic model, in many

${ }^{111}$ In her important book on gender justice within the family, Susan Moller Okin states that matter this way: "The basic problem with the human capital approach is that, like much of neoclassical economic theory, it pays too little attention to the multiple constraints placed on people's choices. It pays too little attention to differentials of power between the sexes both in the workplace and in the family. It thus ignores the fact that women's commitment and attachment to the workplace are strongly influenced by a number of factors that are largely beyond their control." SUSAN MOLLER OKIN, JUSTICE, GENDER, AND THE FAMILY 148 (1989).

112 One commentator recently observed that among economists "the axiom of exogenous preferences is as old as liberal political philosophy itself." Samuel Bowles, Endogenous Preferences: The Cultural Consequences of Markets and Other Economic Institutions, 36 J. OF ECON. LIT. 75, 75 (1998).

${ }^{113}$ See Reuben Gronau, Sex-Related Wage Differentials and Women's Interrupted Labor Careers -- the Chicken or the Egg, 6 J. LAB. ECON. 277, 285-86 (1988) (noting that employer expectations may reduce opportunities for training and promotion). For additional discussions see CyNTHIA B. LLOYD \& BETH T. NIEMI, THE ECONOMICS OF SEX DIFFERENTIALS 313 (1979) (fewer opportunities may reduce incentives for investment); Glenn C. Loury, Discrimination in the Post-Civil Rights Era: Beyond Market Interactions, 12 J. of Econ. Perspectives 117, 123-24 (1998) (explaining how perceptions can become self-fulfilling prophecies); Cass Sunstein, Why Markets Don't Stop Discrimination, 8 SOC. PHIL. \& POLICY 22, 29 (1991) (discussing dynamic effects labor 


\section{Family Leave and the Gender Wage Gap}

instances it would seemingly be rational for women to reduce their investments to the extent those investments fail to return as much in the labor market compared to similar investments committed by men. Facing reduced opportunities for promotion as well as lower wages, and likely having to confront at some point in one's career a decision regarding how best to balance work and family, women may decide it is not worth pursuing extra degrees, experience or training when the investment offers a discriminatory rate of return - keeping in mind, however, that the observed disparities in these factors do not fully explain the disadvantages faced by women. As Professor Vicki Schultz explains, "Like all workers, women adapt their work aspirations and orientations rationally and purposefully, but always within and in response to the constraints of organizational arrangements not of their own making."114

This is one way the "choices" women make can be dramatically influenced by the labor market. Another and perhaps more significant way in which women's choices may be shaped, or constrained, is through social conditioning that affects all of us, male and female alike. ${ }^{115}$ There is a great volume of literature on the role social conditioning plays in creating our gendered world, and in particular in producing our segregated labor market, which I will only touch upon here. ${ }^{116}$ Just as it is difficult to

market can have on human capital investments).

114 Vicki Schultz, Telling Stories About Women and Work: Judicial Interpretations of Sex Segregation in the Workplace in Title VII Cases Raising the Lack of Interest Argument, 103 HARV. L. REV. 1750,1815-16 (1990)..

115 See Joan C. Williams, Deconstructing Gender, 87 MiCH. L. REV. 797, 836 (1989) (challenging the choices that are currently available and arguing for restructuring choices).

${ }^{116}$ For an excellent recent overview on the literature see VALIAN, supra note 5. For additional useful discussions on the theme of social conditioning see, e.g., SANDRA LIPSITZ BEM, THE LENSES OF GENDER 133-75 (1993); BARBARA BERGMAN, THE ECONOMIC EMERGENCE OF WOMEN 40-62 (1986); CYNTHIA FuCHS EPSTEIN, DECEPTIVE DistinCTIONS: SEX, GENDER, AND THE SOCIAL ORDER 80-126 (1988); JUDITH LORBER, PARAdOXES OF GENDER 144-93 (1994); ROBERTA S. SigEL, AMBITION \& ACCOMMODATION 9-23 (1996). 


\section{Family Leave and the Gender Wage Gap}

contest the importance of education and training for obtaining a desirable job, it is equally difficult to dispute that many of our life decisions are significantly influenced by social forces or that those forces tend to operate on a distinctly gendered basis. These forces range from the way boys and girls are treated during infancy, to differential treatment in schools regarding subjects, sports and other elements of school life, to the images we see in the media and all around us. ${ }^{117}$ As noted earlier, the empirical data suggest that women are not choosing jobs that make it easier for them to accommodate their nonmarket activities, and a more convincing explanation appears to be that women are channeled, or crowded, into certain professions and jobs, even though it may appear that these jobs are the product of individual choice. ${ }^{118}$ Consistent with this view, survey data indicate that "[w]omen consistently aspire to more male dominated pursuits than those in which they are employed," 119 suggesting that many women would prefer to be in occupations different from the ones they currently hold.

This is the very point at which the issue becomes complicated for purposes of interpretation, and by using the term "channeling", I am revealing my own biases - biases that admittedly cannot be fully

117 This socialization, what is also sometimes called social control theory, continues throughout our lives. See Jerry A. Jacobs, Gender and Academic Specialties: Trends Among Recipients of College Degrees in the 1980s, 68 Sociology OF EDUCATION 81,96 (1995) ("Social control is not simply a matter of early life socialization that determines all adult behavior; rather, continuing social constraints are required to keep women and men in their sex-appropriate domains.”).

118 See BERGMAN, supra note 116, at 87-114 (discussing ways in which jobs become gendered); BARBARA F. RESKIN \& PATRICIA A. RoOs, Job QUEUES, GENDER QUEUES 10-64 (1990) (discussing how jobs can be transformed from female to male jobs). In her very interesting study of female marines and male nurses, Christine Williams demonstrates how gender roles persist even for those who choose nontraditional occupations. See Christine L. Williams, Gender DifFERENCES AT WorK: Women \& MEN IN NONTRADITIONAL OCCUPATIONS (1989).

119 JACOBS, supra note 64 , at 75 . Jacobs notes that approximately $50 \%$ of women aspire to a male-dominated occupation at some point in their career. Id. at 103. 


\section{Family Leave and the Gender Wage Gap}

supported by the data. ${ }^{120}$ Indeed, in deciding between choice or social construction, no data can provide a conclusive explanation, as even the best data would likely be tainted by structural issues affected by discrimination. This is certainly true of the question posed earlier whether women are expressing preferences or responding to opportunities, and even during interviews, we would not necessarily expect women to state that they chose their job because social forces had limited their opportunities or structured their decisions. ${ }^{121}$ Rather, any explanation would likely involve numerous reasons and motivations, all of which were influenced by a complex array of forces, some known and some unknown. ${ }^{122}$

120 There are also those who believe that our gendered choices are the product of biology, a movement that seems to be gaining some steam in the form of sociobiology. For a popular account see ROBERT WRIGHT, THE MORAL ANIMAL (1995). For a contrary view, namely that biology determines virtually none of our behaviors, see JOHN DUPRE, THE DisORDER OF THINGS: METAPHYSICAL FOUNDATIONS OF THE DiSUNITY OF SCIENCE (1993). This is an issue on which there is strong disagreement and what seems to me profound ideological interests tied to the various interpretations. As one commentator has aptly noted, "The debate over nature looks depressingly insoluble. Both sides can recognize the biological evidence, for what it is worth; but they give it different significance." Julia Annas, Women and the Quality of Life: Two Norms or One? at 293, in THE QuALITY OF LIFE (Martha Nussbaum \& Amartya Sen, eds. 1993). For a recent attempt to find some middle position see Melvin Konner, Darwin's Truth, Jefferson's Vision, AMERICAN PROSPECT 30 (July-Aug. 1999).

121 Elizabeth Anderson makes the interesting suggestion that we should look at people's attitudes about their choices rather than their revealed preferences. "Individuals have positive or negative attitudes toward their choices," she argues, "which reveal how well their choices reflect the valuations they have of themselves and others." ELIZABETH ANDERSON, VAlUE In ETHICS AND ECONOMICS 202 (1993). Although people's attitudes may provide more reliable information then their actual choices, attitudes are also strongly shaped by choices, as people seek to adapt to what is available to them. This insight is animating much of what is now becoming known as Behavioral Law and Economics, though to my mind the best (and most entertaining) discussion of the issue remains JON ELSTER, SOUR GRAPES (1983).

${ }^{122}$ For a recent discussion involving the difficult issue of determining "when can we say that our choices are truly our own," see LAWRENCE E. MitCHELL, STACKED DECK 101-32 (1998). 


\section{Family Leave and the Gender Wage Gap}

This is what is important to keep in mind, the sheer multitude of forces that play a role in our decisionmaking, leading to what Louis Althusser defined, in a different context, as a state of semi-autonomy. ${ }^{123}$ To be sure, many individual women choose non-traditional jobs, and just as many women undoubtedly happily choose traditional female roles relatively free of social constraints, and it is also important to recognize that many people are able to exercise more choice in their lives than others. At the same time, it is surely impossible to deny the substantial sex segregation that continues to define the labor market, and that the segregation cannot be fully accepted as the product of unconstrained choice. As Deborah Rhode argues, "[T]o an important extent, women's preferences are socially constructed and constrained. The state does not simply respond to expressed desires; it plays an active role in legitimating, suppressing, or redirecting them." ${ }^{124}$

It is, thus, necessary to craft a theory that best explains what we do know regarding the role of preferences and choice in determining labor market inequality. And what we do know is that women continue to be paid less, receive less responsibility, and fewer opportunities for promotions than their male counterparts - and that a large number of women, perhaps all in some way, are penalized by the decision of some women to leave the workforce to care for their children. We also know that the explanations proffered by neoclassical economic models have not been sufficiently supported by empirical studies; based on those studies it would be difficult to suggest that women's choices, even if freely derived, explained the persistent inequalities. Additionally, we know that the definition of equality that gains the widest acceptance is that of equality of opportunity, ${ }^{125}$ and we also know that currently women and

123 See Louis AlthusSER, For MARX 138 (B. Brewster trans. 1977).

124 Deborah L. Rhode, Changing Images of the State: Feminism and the State, 107 HARV. L. REV. 1181, 1189 (1994).

125 This is obviously a controversial statement on which countless books and articles have been written, and there are certainly many variants on the theme of equality. In his compelling account of equality, Amartya Sen, for example, argues that the 


\section{Family Leave and the Gender Wage Gap}

men do not face the same opportunities, and that if we are to move to a greater level of equality, at a minimum women must be afforded the choices and opportunities provided to men. Only then, if women continue to make different choices, could we properly assert that the choices are a matter of preferences.

This is not to suggest that we take the male role in the labor market as the norm. On the contrary, as developed more fully in section III.B., I will argue that legislative solutions should effectively treat women as the norm in the workplace. What I mean to suggest here is that women should not be penalized for their perceived or expected behavior, and that equalizing choices between men and women may entail changing the choices currently available to both men and women. ${ }^{126}$ But before discussing various strategies that may enable us to break up the prevailing patterns, it will be useful to first discuss another theory - that of statistical

"[e]quality of freedom to pursue our ends cannot be generated by equality in the distribution of goods" but must instead be concerned with creating the conditions that provide individuals with the capability to achieve their chosen ends. See AMARTYA SEN, INEQUALITY REEXAMINED 39-55 (1992). That said, I feel comfortable in asserting that equality of opportunity is the most widely shared conception of equality since the concept of equality of opportunity is important to all theories of equality, with the dispute largely over whether it is a sufficient condition as well as the necessary conditions for achieving a state where equality of opportunity can be a reality.

126 At this point, it may be helpful to make clear that I am not advocating that women be permitted to work part-time while maintaining full-time pay, benefits and promotional opportunities, or that there be no penalty for lengthy absences from the labor market. Although it is difficult to dispute the attraction of part-time work at full-time pay, requiring employers to ignore hours and substantial labor market absences may impose too onerous a burden that would require overlooking real evidence regarding productivity. Increasing part-time work for women, with benefits, is the strategy present in many European countries, particularly the Netherlands where a very low percentage of women with children work full-time. See Cristina Duarte, The Family and Medical Leave Act of 1993: Paying the Price for an Imperfect Solution, 32 U. OF LOUISVILLE J. OF FAMILY LAW 833, 847 (1994). In the United States, it seems highly unlikely that we will move towards non-marginalized part-time work - work that offers good wages and benefits, as well as opportunities for advancement - so that moving toward creating more part-time work does not appear to be a viable means toward reducing existing labor market inequality. 
discrimination - that is often used to explain women's continued labor market status.

\section{The Role of Statistical Discrimination.}

I have so far reviewed two important explanations for the continued and persistent gender inequality that continues to plague the workplace, namely differences in human capital investments and the role "choice" plays in perpetuating gender patterns. If neither of these theories explains the observed gender inequalities, then what does? A theory that is becoming increasingly important is known as statistical discrimination, a concept that has had its strongest influence within economics although it is playing a growing role within law as well. ${ }^{127}$ The theory of statistical discrimination, discussed in detail below, is generally treated as separate from the human capital explanation, but the ideas are closely related, and the perceived differences in human capital investments fully animate the concept of statistical discrimination, which often serves as a catch-all theory to explain what is otherwise left unexplained by the data. In other words, the notion of statistical discrimination is used primarily to fill in the gaps left by other economic explanations; for example, to the extent human capital investments do not fully explain wage disparities the

127 The earliest articulation of the concept within economics is Edmund S. Phelps, The Statistical Theory of Racism and Sexism, 62 AMER. ECON. REV. 659 (1972). For additional discussions see Dennis J. Aigner and Glen G. Cain, Statistical Theories of Discrimination in Labor Markets, 30 INDUS. \& LABOR REL. REV. 175 (1977); Kenneth J. Arrow, Models of Job Discrimination, in RACIAL DISCRIMINATION IN ECONOMIC LIFE 83 (Anthony H. Pascal ed., 1972); Stewart Schwab, Is Statistical Discrimination Efficient? 76 AMER. ECON. REV. 228 (1996). For helpful discussions within law, most of which are critical of the concept see Ian Ayres, Fair Driving: Gender and Race Discrimination in Retail Car Negotiations, 104 HARV. L. REV. 817, 850-52 (1991); David Charny \& G. Mitu Gulati, Efficiency Wages, Tournaments, and Discrimination: A Theory of Employment Discrimination for "High Level” Jobs, 33 HARV. C. R.-C.L. L. REV. 57, 6385 (1998); Drucilla Cornell \& William W. Bratton, Deadweight Costs and Intrinsic Wrongs of Nativism: Economics, Freedom, and Legal Suppression of Spanish, 84 CoRNELl L. REV. 595 (1999); David A. Strauss, The Law and Economics of Racial Discrimination in Employment: The Case for Numerical Standards, 79 GEO. L.J. 1619 (1991). 
remaining unexplained portions are often attributed to statistical discrimination. But, as I will argue below, there is very little reason to believe that employers' policies, with respect to compensation and hiring practices, are adequately explained by the idea of statistical discrimination, or at least statistical discrimination that ought to be treated as a rational employer policy. ${ }^{128}$

\section{The Theory of Statistical Discrimination.}

The general concept of statistical discrimination is relatively straightforward: when employers lack perfect information, and where it would be too costly to collect such information, they will resort to group averages to determine the potential productivity of individuals. ${ }^{129}$ In the context of this article, this means that employers will often treat women differently from men because, on average, women are more likely to leave the workforce to have and to raise children, and these potential exits can be costly for employers. ${ }^{130} \mathrm{With}$ respect to prospective employees, relying on group averages can be particularly important because it is often difficult for an employer to obtain reliable information in advance as to the likelihood that any particular individual will later leave the workforce. One reason for this is that it is potentially unlawful for employers to ask

128 Indeed, the more the facts deviate from the theory, statistical discrimination begins to resemble animus-based discrimination. See CYNTHIA B. LlOYD \& BETH T. NIEMI, THE ECONOMICS OF SEX DifFERENTIALS 201 (1979) ("[A] theory of statistical discrimination based on erroneous estimates of female productivity comes very close to the theory of discrimination based on prejudice."); Michael Selmi, Testing for Equality: Merit, Efficiency, and the Affirmative Action Debate, 42 UCLA L. REV. 1251, 1294 (1995) (arguing that "statistical race discrimination starts to appear analytically indistinguishable from taste discrimination").

129 See EHRENBERG \& SMITH, supra note 44, at 440-43.

${ }^{130}$ For a discussions along these lines see Samuel Issacharoff \& Elyse Rosenblum, Women and the Workplace: Accommodating The Demands of Pregnancy, 94 Colum. L. REV. 2154, 2168-69; Edward J. McCaffery, Slouching Towards Equality: Gender Discrimination, Market Efficiency, and Social Change, 103 YALE L.J. 595 (1993). 


\section{Family Leave and the Gender Wage Gap}

applicants, especially if they only ask their female applicants, but more significantly, the question will rarely yield accurate information as employees know, or can reasonably predict, the desired answer. To the extent employers believe this information is important, it is often contended that they are left to rely on their group observations as the best available information. ${ }^{131}$

As a concept, there is nothing particularly insidious about relying on statistical information to make judgments about individuals. After all, that is how law schools make most of their admission decisions, ${ }^{132}$ and hardly a day goes by when we don't resort to group averages as the basis for some sort of prediction or determination. Yet, relying on group observations can also lead to unfair treatment, and in the workplace, statistical discrimination based on gender is generally unlawful -- even where it might be efficient. ${ }^{133}$ With this in mind, it is important to see just how inaccurate the use of statistical information can be and how it affects all women, even those who display persistent workforce attachment throughout their careers.

\section{Is Statistical Discrimination Justified?}

131 See, e.g., McCaffery, supra note 130, at 620.

${ }^{132}$ Law schools typically place substantial weight on LSAT scores, which offer group prediction about the likelihood of success during the first year. See Michael A. Olivas, Constitutional Criteria: The Social Science and Common Law of Admissions in Higher Education, 68 U. COLO. L. REV. 1065 (1997) (discussing role of LSAT in admissions decisions). As is well known, these scores are quite inaccurate as to particular individuals but offer some prediction for the group as a whole, which captures the essence of statistical discrimination.

133 See Los Angeles Dept. of Water \& Power v. Manhart, 435 U.S. 702 (1978). In Manhart, the Supreme Court invalidated a state policy that required female employees to make higher pension contributions than men because women tend to live longer and thus, as a class, would likely receive greater pension benefits than men. Although the parties, and the Court, accepted as true the factual basis for the policy, the Court held that the practice was "in direct conflict with both the language and the policy of the Act." Id. at 712. See also Arizona Governing Committee v. Norris, 463 U.S. 1073 (1983) (invalidating sex-based practice of paying out less to women). 
Earlier we saw just how inaccurate the theory of statistical discrimination is when applied to women's likely workforce behavior. After having children, most women return to their prior working condition within four to six months, with most women returning to the kind of work and hours they had before giving birth. ${ }^{134}$ What this means is that on average, the women who had a weak labor force commitment prior to having children will be the ones most likely not to return to work, or to quit their position after having returned for some period of time and finding the demands of work and family too taxing. ${ }^{135}$ Yet, as previously noted, employers contend that because it is difficult to know who those employees will be - just as it is difficult to know in advance who the committed or superior employees will ever be - it is efficient for them to resort to their gender barometer knowing that it remains more likely that women will leave the workforce than men. This reliance on gender data can play itself out in subtle ways, such as not granting women long-term assignments, not reaching out to mentor the young employee, or evaluating their work product differently because the evaluation is tinged with a different view of women's commitment to the workforce. ${ }^{136}$

The use of statistical information in this fashion is routinely treated as an efficient employment practice, and is often referred to as

134 See text accompanying notes 83-85 supra.

135 See Light \& Ureta, supra note 98, at 179-80 (finding no evidence that it is more difficult to identify female nonquitters than male).

136 VALIAN, supra note 5, at 210-26 (discussing ways discrimination can adversely affect women's careers in academia); Deborah L. Rhode, Myths of Meritocracy, 65 FORDHAM L. REV. 585, 587 (1996) ("female lawyers consistely report receiving fewer opportunities for mentoring, business development, and desirable assignments than their male colleagues."). For an excellent discussion for how these issues arise in law firms with respect to racial stereotypes see David B. Wilkins \& G. Mitu Gulati, Why Are There So Few Black Lawyers in Corporate Law Firms? An Institutional Analysis, 84 CALIF. L. REV. 493 (1996). 


\section{Family Leave and the Gender Wage Gap}

rational discrimination. ${ }^{137}$ This argument, however, embodies some of the sophistry that defines much of traditional law and economics: namely the notion that if it were not efficient, employers would not do it. ${ }^{138}$ There are by now well-developed explanations for why employers may engage in practices that cannot be properly described as rational, which will be discussed in more detail below, ${ }^{139}$ but I here want to explain as a theoretical matter why the assumption of rationality that underlies statistical discrimination is plainly overbroad. Whether the practice of treating women differently because of their greater propensity to leave the workforce to care for children is truly efficient involves an empirical

137 See EdWARD MCCAFFERY, TAXING WOMEn 243 (1997) ("From the employer's point of view, statistical discrimination is 'rational' or efficient and profitmaximizing."); EDMUND S. PHELPS, REWARDING WORK 114 (1997) (discussing rational discrimination); James Albrecht \& Susan Vroman, The Gender Gap in Compensation: Evaluating Policies to Reduce the Gender Gap, An Economic Approach, 82 GEO. L.J. 69, 72 (1993) ("It is rational for an employer with such beliefs to engage in statistical discrimination in the sense of requiring that female applicants for good jobs show more objective evidence of a long-term commitment to the workforce than must their male counterparts."); Susan Bisom Rapp, Of Motives and Maleness: A Critical View of Mixed Motive Doctrine in Title VII Sex Discrimination Cases, 1995 UTAH L. REV. 1029, 1089 (equating statistical discrimination with rational discrimination); Keith N. Hylton \& Vincent D. Rougeau, Lending Discrimination: Economic Theory, Econometric Evidence, and the Community Reinvestment Act, 85 GEO. L.J. 237, 247 (1996) ("the theory of statistical discrimination ... posits that racial discrimination reflects rational predictions of the behavior of the group subject to discrimination."); Cass Sunstein, The Anticaste Principle, 92 MiCH. L. REV. 2410, 2452 (1994) ("Insofar as statistical discrimination is outlawed, the government has singled out one form of rational categorization."); Amy L. Wax, Discrimination As Accident, 74 IND. L.J. 878, 922 (1999) (identifying statistical discrimination as rational discrimination).

138 Robert Kuttner explains: "Economists enamored of pure markets begin with the theory, and hang models on assumptions that cannot themselves be challenged . . . [I]f wages for manual workers are declining, it must be that their economic value is declining . . If commercial advertising leads consumers to buy shoddy or harmful products, they must be 'maximizing their utility' ... How do we know that? Because to do anything else would be irrational. And how do we know that individuals always behave rationally? Because that is the premise from which we begin." ROBERT KUTTNER, EVERYTHING FOR SALE: THE VIRTUES AND LIMITS OF MARKETS 9 (1998).

139 See text accompanying notes $156-67$, infra. 
question that is very rarely tested and is generally context dependent. ${ }^{140}$ At a minimum, determining the efficiency of relying on group averages would require knowing what the costs of the labor market disruptions actually are, as well as their expected probability, and those costs would then have to be compared to the lost productivity that occurs through the differential treatment women receive - the costs of the lack of mentoring, or the devaluation of women's work product, and the higher turnover that might resort from this treatment. ${ }^{141}$ It would also be important to know the cost of obtaining more individualized information, which in any calculus should be weighed against the costs of engaging in statistical discrimination.

Let me sketch an example. Suppose an employer believes there is a thirty percent chance a female employee will not return from work after having a child. In determining the cost of that disruption, an employer would want to first assess the cost of the potential turnover, which would take into account its normal turnover rate as it would be highly unusual for an employer to have no turnover at all. Assuming a firm has some turnover, one would then want to determine the marginal cost of the turnover associated with the potential that an employee will not return to work to care for a child. As discussed in the next section, employers have had little trouble covering employees on temporary maternity leave, and in many jobs, replacement costs associated with additional individuals are not particularly high because they are so routine. ${ }^{142}$ In this respect, it is not the absolute cost of a replacement that matters but the marginal or relative cost that should concern an employer.

Balanced against those costs, would be the costs of relying on

140 See Light \& Ureta, supra note 98, at 158 (noting that "any conclusion about whether statistical discrimination is "justified" depends entirely on which birth cohorts are being examined.").

141 See Valian, supra note 5, at 174-86 (discussing the effects of discrimination on women's careers).

142 See infra text accompanying notes 209-10. 


\section{Family Leave and the Gender Wage Gap}

group averages. Assuming an employer is considering not hiring or promoting women, or reducing its hiring or promotions of women, that employer would want to know the costs that might arise from foreclosing an entire group of qualified applicants, particularly when the firm's competitors may reap the benefits of that policy. A firm with a poor reputation for hiring or retaining women will suffer some market disadvantage in hiring women, leaving them potentially with a lower quality applicant pool. Similarly, if a firm chooses to pay women less, or to invest in them less, there might also be a corresponding loss in productivity while the employee is on the job, and that loss may spillover to other employees. Male employees who know that their female counterparts are at a competitive disadvantage may reduce their own work effort in response to their competitive edge. ${ }^{143}$

An important additional factor that needs to be weighed in the efficiency calculus is the length of the expected labor force disruptions, as it would certainly be unjustified for an employer to treat any leave as unduly costly, or all leaves as equally costly. While permanent exits may be costly (depending on the job and its natural turnover rate), the short labor force disruptions of most women should not create equivalent costs. ${ }^{144}$ An employee's skills are unlikely to recede with any time off from the labor market, though at a certain point, depending on the nature of the job, there is likely to be some significant loss of skill. For example, a lawyer taking six months off is likely to miss little that cannot be regained quickly, while taking two or three years off may lead to a significant depreciation, as new cases are decided, and skills honed in the

${ }^{143}$ See Andrew Schotter \& Keith Weiglet, Asymmetric Tournaments, Equal Opportunity Laws, and Affirmative Action: Some Experimental Results, 107 Q. J. OF ECON. 511 (1992) (applying tournament theory to the workplace); Selmi, supra note 128 at 1304-05 (discussing ways in which employers create workplace competition to spurn productivity).

144 This is also true with respect to turnover that occurs early in a career since such turnovers are frequent among both men and women. See Light \& Ureta, supra note 98 , at 157 (noting the high propensity of "young workers ... to quit their jobs regardless of gender."). 
courtroom or elsewhere, recede. ${ }^{145}$

As a result, from the statistical discrimination prism, the question of interest for an employer ought to be determining the cost from a fourmonth leave that may occur once or twice in the course of a career, rather than assuming that women are likely to exit the labor market permanently. ${ }^{146}$ Although productivity is notoriously difficult to measure, when the issue is placed in this stark framework, the cost of the workforce disruption to employers does not appear so daunting, especially when measured against other anticipated work disruptions, such as sickness, vacation, illness, injury, or jury service. Indeed, to know whether employers are engaging in a form of statistical discrimination that ought to be defined as rational, as opposed to stereotypical or animus-based decisionmaking, it is important to know how employers weigh these other potential labor market disruptions for which individualized predictive information is difficult to obtain. Given that most leaves for childbirth are of short duration, predictable and infrequent, it seems irrational for an employer to single out pregnancyrelated leave for particular treatment among all the potential labor force disruptions.

Yet, discussions concerning statistical discrimination and the gender gap often treat childbearing as if it were the only condition that employees bring to the labor market that may impose costs on employers. There are, however, an abundance of other conditions that may impose equal or higher costs that rarely seem to be taken into account. An employer concerned with potential lost productivity due to workplace disruptions might want to screen out those employees who are prone to alcoholism, illnesses or injuries, all of which are more prominent among

145 Again, this will depend on the particular job -- some tasks, estate planning comes to mind, may not experience an erosion of skills at all.

146 As noted earlier, this is the average length of leave for childbearing. See supra text accompanying notes 83-85. Within the statistical discrimination model, the average is the appropriate figure to use. See EHRENBERG \& SMITH, supra note 44, at 41. 


\section{Family Leave and the Gender Wage Gap}

men. Recent statistics indicate that men are three times as likely as women to be binge drinkers and four times as likely to be heavy drinkers, with twenty-three percent of men defined as binge drinkers. ${ }^{147}$ Similarly, "women incurred less than one-tenth of job-related fatal injuries and onethird of the non-fatal injuries and illnesses that required time off to recuperate." ${ }^{148}$ In other words, there are lots of adverse behaviors employees bring to the workplace that correlate with gender, and it is difficult to imagine, and certainly wrong to assume, that the only differences that matter are the potential short-term exits of women to have children.

Finally, another factor that may cast doubt on whether rational statistical discrimination truly explains an employer's behavior is that it would be most efficient for employers to use such knowledge or information in the hiring process, where it is often difficult to assess an employee's likely future labor force behavior. Once an employee is on the job, the employer is in a position to collect reliable information unavailable at the time of hire, especially given that past employment behavior remains the best predictor of future workforce attachment. ${ }^{149}$ Yet, there is substantial evidence that women are disadvantaged throughout their careers, and considerable evidence to suggest that more discrimination occurs after rather than before hiring. ${ }^{150}$

147 See National Household Survey on Drug Abuse, Preliminary RESUltS FROM THE 1997 HOUSEHOLD SURVEY ON DRUG ABUSE at Tables 15 \& 16 (1998).

148 GARY A. TOSCANO ET AL., Work Injuries and Illnesses Occurring to Women, 3 COMPENSATION AND WORKING CONDITIONS 16 (1998) (footnote omitted). As a way of reducing costs further, employers may also wish to screen out those most likely to engage in sexual harassment, which costs the employer both in legal judgments and also in the reduced productivity of both the harasser and the victim of the harassment

149 See text accompanying notes 93-95 supra.

150 See VALIAN, supra note 5, at 225 (observing that in academia "recent female graduates start out on an equal salary footing . . . but lose that equality as early as three to eight years post-PhD."); William T. Bielby \& Denise T. Bielby, supra note 36, at 223-25 (finding continuous disadvantage faced by female television writers throughout their 
The above discussion suggests that the assumption that statistical discrimination is rational and efficient is not well grounded, and at a minimum involves a far more complicated analysis than is generally assumed. However, even if we treat the use of statistical information to disadvantage women as an efficient practice, there are social costs that need to be considered in evaluating the desirability of the practice. By its very nature, statistical discrimination is overbroad in its reach, which means that relying on group averages has its greatest adverse effect on those individuals who do not fit the average, or the assumed average, in this case, those women who do not leave, and do not intend to leave, the workforce for family commitments. ${ }^{151}$ The result of this overbroad judgment is that the employer will waste, or underutilize, talent, and may find higher turnover among its female employees, all of which negatively affects our social welfare..$^{152}$

career); Jerry A. Jacobs, Women's Entry Into Management: Trends in Earnings, Authority, and Values Among Salaried Managers, 37 ADMINISTRATIVE SCIENCE Q. 282, 290 (1992) (documenting discriminatory pay patterns among female managers); Janet Rosenberg, et al., Now That We Are Here: Discrimination, Disparagement, and Harassment at Work and the Experience of Women Lawyers, 7 GENDER \& SOCIETY 415, 422 (1993) (found more perceived discrimination on the job than in hiring among female lawyers).

151 See VALIAN, supra note 5, at 257 (discussing how statistical discrimination makes life difficult for all women).

152 See Shelly J. Lundberg \& Richard Startz, Private Discrimination and Social Intervention in Competitive Labor Markets, 73 AMER. ECON. REV. 340 (1983) (arguing that statistical discrimination can lead to "suboptimal levels of human capital"). The question whether women have a higher turnover rate than men has generated considerable controversy. Both men and women tend to have unstable early careers as they search for better experience and job matches, and those experiences do not seem to negatively affect labor job patterns. See Gardecki \& Neumark, supra note 40, at 18-19 ("We find that adult labor outcomes (defined as of the late 20s or early to mid-30s) are for the most part unrelated to the stability of early labor market experiences . . .); Light \& Ureta, supra note 83, at 157 ("While women are more prone than men to leave the labor force, the fact is that young workers are likely to quit their jobs regardless of gender."). A recent study of a large insurance company found that while women had a higher quit rate early in their career, after five years with the firm women were thereafter less likely than men to leave 


\section{Family Leave and the Gender Wage Gap}

This does not mean that the theory of statistical discrimination fails to offer some explanatory power as to why women are paid less, and offered fewer promotional opportunities than men. On the contrary, I believe the theory provides important insights into employer's practices, as employers do seem to take into account women's greater likelihood of leaving the workforce to have children in their employment decisions. But they do so in an exaggerated way, and such practices are at best crude and likely inefficient, or at least as likely to be inefficient as efficient, and certainly should not be tolerated to the extent they are based on inaccurate perceptions of women's labor market attachment, perceptions that, as discussed earlier, might become self-fulfilling prophecies as women adapt to the lesser opportunities available to them.

\section{The Need for Government Intervention.}

At this juncture, the traditional neoclassical economic model would still likely resist the heed for governmental intervention. To the extent employers continue to rely on inaccurate group averages, according to the neoclassical model, the practice is unlikely to persist since competitive market pressures would eventually eliminate the use of these averages. Firms that relied on better information would ultimately obtain a more efficient workforce and thus drive out the less efficient competitors. ${ }^{153}$ This is a familiar but rather tired argument that has lost

their employment. See Nachum Sicherman, Gender Differences in Departures From A Large Firm, 49 INDUS. \& LABOR REL. L. REV. 484 (1996). Women do seem to suffer a greater penalty for early turnover, likely because of their stronger need to signal workplace commitment to employers. Gardecki \& Neumark, supra at 319. Women also tend to work in industries with higher turnover rates. See W. Kip Viscusi, Sex Differences in Worker Quitting, 62 REV.ECON. \& STAT. 388, 397 (1980) (“Almost the entire predicted male-female quit difference and half of the actual difference can be explained by differences in their jobs and regional economic conditions.").

153 The classic elaboration of the theory, although developed in the context of animus rather than statistical discrimination, is GARY S. BECKER, THE ECONOMICS OF DISCRIMINATION (2d ed. 1971). Although it has largely gone unnoticed, Becker has since claimed that his theory has been misunderstood, as he originally argued that firm production functions, as well as discrimination by employers and customers could sustain 


\section{Family Leave and the Gender Wage Gap}

most of its appeal outside of law. ${ }^{154}$ Within the economics and sociological literature, it is now widely acknowledged that competitive market pressures have not, and will not, eliminate broadscale discrimination in labor markets. ${ }^{155}$

One reason why discrimination persists in labor markets is that so many employees are ready substitutes for each other, accordingly, an employer may not lose much by choosing a male over a female candidate for a particular position, even though there is no productivity-based

discriminatory practices. See GARY S. BECKER, ACCOUNTING FOR TASTES 142 (1996).

154 For recent legal discussions see Wayne R. Cohen, An Economic Analysis of the Issues Surrounding AIDS in the Workplace: In the Long Run, the Path of Truth and Reason Cannot be Diverted, 41 AMER. U. L. REV. 1199 (1992) (noting that firms are unlikely to maintain discriminatory workplace); Roderick M. Hills, Jr., Sex, Law \& Equality: You Say You Want a Revolution? The Case Against the Transformation of Culture Through Antidiscrimination Laws, 95 MicH. L. REV. 1588, 1622 (1997) (arguing that employers will likely forego discrimination in competitive markets); Hylton \& Rogeua, supra note --, at 250-51 (suggesting lending discrimination should not persist in a competitive market); Peter Swire, The Persistent Problem of Lending Discrimination: A Law and Economics Analysis, TEXAS L. REV. 787, 840 (1995) (same).

155 For an excellent discussion of the various economic theories of discrimination and their inability to explain the persistence of labor market discrimination see Jeremiah Cotton, Labor Markets and Racial Inequality, in LABOR ECONOMICS: PROBLEMS IN ANALYZING LABOR MARKETS 183-208 (William Darity, Jr. ed., 1993); see also Kenneth J. Arrow, What Has Economics to Say About Racial Discrimination, 12 J. OF ECON. PERSPECTIVES 91 (1998) (discussing ways in which race discrimination can survive even in competitive markets); William A. Darity \& Patrick L. Mason, Evidence on Discrimination in Employment: Codes of Color, Codes of Gender, 12 J. OF ECON. PersPeCtives 63, 82-87 (1998). For discussions relating to gender see Mary E. Becker, Needed in the Nineties: Improved Individual and Structural Remedies for Racial and Sexual Disadvantages, 79 GEO. L.J. 1659, 1673 (1991) (arguing that unrealistic to expect the market to eliminate sex discrimination because women are undervalued and segregation creates employment taboos); Paula England, Wage Appreciation and Depreciation: A Test of Neoclassical Economic Explanations of Occupational Sex Segregation, 62 Soc. FORCES 726, 741-42 (1984) (suggesting theory fails to explain sex segregation); Paul Milgrom \& Sharon Oster, Job Discrimination, Market Forces and the Invisibility Hypothesis, 102 Q. J. OF ECON. 453 (1987) (arguing that because skills and abilities of women and minorities are undervalued they remain invisible in the marketplace). 


\section{Family Leave and the Gender Wage Gap}

reason to do so. ${ }^{156}$ Additionally, discrimination may persist in labor markets, as John Donohue has argued, because employees in the labor market often have restricted mobility and therefore are unable to gravitate to nondiscriminating employers, distinguishing the labor market from the stock market and creating another barrier to market clearing. ${ }^{157}$ Whether or not these facts make an employer's practices efficient, as noted earlier is ultimately a difficult empirical question, but we certainly know that discrimination has persisted to a far greater extent than neoclassical economic theory predicted. As economist Barbara Bergmann commented some time ago: "We see thousands of business failures every year in the United States, so firms do make fatal mistakes; but no one has ever reported seeing a firm that discriminated reduced to ruin by a less bigoted competitor," 158 a statement that still holds true today.

Another reason for the stubborn pace of change is that old habits die hard. The practices that may be inefficient in some sense and yet have become an accepted part of a business practice may also become part of that business culture and thus difficult to uproot. As Kenneth Arrow has recently noted, the network of personal interactions that form a business culture can "leave plenty of room for discriminatory beliefs and preferences to play a role which would be much less likely in a market subject to competitive pressures." ${ }^{159}$ These interactions include word of mouth hiring, biases that factor into selection processes that render those selecting individuals prone to choosing someone most like themselves. ${ }^{160}$

156 See Charny \& Gulati, supra note 127, at 76-77 (discussing low costs of discrimination when employees are alike).

157 See John J. Donohue, III, Employment Discrimination Law in Perspective: Three Concepts of Equality, 95 MICH. L. REV. 2583, 2596-97 (1994).

${ }^{158}$ BERGMANN, supra note 116, at 139.

159 Arrow, supra note 155, at 98. In the same article, Arrow acknowledges that there is evidence of racial discrimination in the economy today. Id. at 99.

$160 I d$. at 98 (noting that " $[\mathrm{t}]$ he network model seems most appropriate for the labor market ...”); see also Bratton \& Cornell, supra note 127, at 624-30 (explaining how 


\section{Family Leave and the Gender Wage Gap}

There is also considerable evidence that individuals tend to resist information that contradicts their existing stereotypes, providing yet another reason why statistical discrimination may outlast its empirical foundation. It is now well-documented that individuals seek out information that will confirm their stereotypes, while ignoring or downplaying contrary information. ${ }^{161}$ Consistent information typically remains more salient so that a woman who leaves the workforce after having a child is likely to be remembered whereas the women who return after a month or two of leave are not. ${ }^{162}$ As Virginia Valian explains, "We interpret the information we receive about women ... in the light of our beliefs." 163

English-only rules are often motivated by in-group bias); Bradford Cornell \& Ivo Welch, Culture, Information and Screening Discrimination, 104 J. PoL. ECON. 542, 561 (1996) (arguing that individuals favor associating with people of their own type because they believe it is easier to judge their abilities).

161 See John M. Darley \& Russell H. Fazio, Expectancy Confirmation Processes Arising in the Social Interaction Sequence, 35 AM. PSYCHOL. 867,876 (1986) (noting that "[a] great deal of research suggests that ambiguous behaviors tend to be perceived in a biased manner."); Charles Lord et al., Biased Assimilation and Attitude Polarization: The Effects of Prior Theories on Subsequently Considered Evidence, 37 J. OF PERSONALITY \& SOCIAL PSYCHOLOGY 2098, 2099 (1979) (contending that in the face of ambiguous evidence people emphasize confirmatory evidence while discounting nonconfirmatory information); Matthew Rabin, Psychology and Economics, 36 J. OF ECON. LIT. 11, 26 (1998) ("A range of research suggests that once forming strong hypotheses, people are often too inattentive to new information contradicting their hypotheses."); David M. Sanbomatsu et al., Overestimating Causality: Attribution Effects of Confirmatory Processing, 65 J. PERSONALITY \& SOC. PSYCHOL. 892, 899 (1993) (concluding that people use biased strategies so that causal hypotheses are confirmed).

162 Rabin, supra note 161, at 30 ("A pervasive fact about human judgment is that people disproportionately weight salient, memorable, or vivid evidence ..."); Rhode, supra note 136, at 587 (noting that the confirmatory bias means that mothers who leave early will be remembered though not the times when they stay late).

163 VALIAN, supra note 5, at 168. For an extended treatment of cognitive psychology and how it might inform our analysis of discrimination issues see Linda Hamilton Krieger, The Content of our Categories: A Cognitive Bias Approach to Discrimination and Equal Employment Opportunity, 47 STAN. L. REV. 1161 (1995). 


\section{Family Leave and the Gender Wage Gap}

Finally, an important, and I believe a closely related reason, such habits die hard is that those in power, in this instance men, are reluctant to relinquish that power and thus seek in a variety of often subtle ways to preserve their privileged positions. They do this not necessarily out of animus, but more out of a desire to vindicate, and preserve, their place in society. ${ }^{164}$ People naturally want to believe their success is a result of just procedures and talent, even if we all know this is not always the case given that so much of our society is rooted in illegitimate and discriminatory processes that have long coattails, processes that were often intended to subordinate women. ${ }^{165}$ While the means of that subordination have surely lessened, they remain stubbornly in place and help explain why change has not occurred more quickly. It is also important to note that men have a great deal invested in preserving gender roles, both as a way of understanding their world and as a means to enhancing their individual economic well-being. Reducing gender inequality in the workplace may cause a reevaluation of "men's" and "women's" work and may also decrease the income and prestige of men,

164 See, FAye J. Crosby, Juggling: The UneXPECtEd AdVANTAgES OF BALANCING CAREER \& HOME FOR WOMEN AND THEIR FAMILIES 158-77 (documenting subtle patterns of male resistance); JUDITH LORBER, PARADOXES OF GENDER 225-52 (1994) (describing ways in which men "guard the gates").

165 Susan Moller Okin argues that husbands often exert influence over their wive's decisions not out of a "concern for aggregate welfare of the household but . . by their desire to retain the authority and privilege that accrues to them by virtue of being the family's breadwinner." OKIN, supra note 111, at 147. Kathy Abrams has also recently forcefully demonstrated how sexual harassment has been used as a means of establishing male control and masculine norms in the workplace. See Kathryn Abrams, The New Jurisprudence of Sexual Harassment, 83 CORNELL L. REV. 1169, 1205-1218 (1998). Even Judge Posner has recently argued that men may want to expel women from the workplace as a way of preserving status. See Gertrud M. Fremling \& Richard A. Posner, Status Signaling and The Law, With Particular Application to Sexual Harassment, 147 U.PA. L. REV. 1069, 1084-85 (1999). For an interesting discussion as to how this process of gender definition and subordination occurs see Karen D. Pyke, Class-Based Masculinities: The Interdependence of Gender, Class, and Interpersonal Power, 10 GENDER \& SOCIETY 527 (1996). . 
even though it is likely to increase family income overall. ${ }^{166}$ Changing the given roles, may also send a signal of condemnation to previous generations, one that is sure to be resisted. Suggesting that men need to take time off to care for their children, for example, may imply that an earlier generation were not as good fathers as they should have been, or believed they were, or that the old model has outlasted its utility.

This focus on preserving privilege is somewhat difficult to square with an economic focus, but it highlights why we must not make efficiency the touchstone of our legal strictures, and why also we should not assume that the market is a frictionless machine grinding its way toward maximizing our social welfare. On the contrary, the use of statistical discrimination perpetuates gender stratification and inequality, and therefore reduces our social welfare. In this respect, the social cost of statistical discrimination may be far greater than the private cost to firms, given that individual firms are not likely forfeiting significant profits through their policies while socially we pay the cumulative cost. ${ }^{167} \mathrm{~A}$ society committed to gender equality, to providing equality of opportunity to women, should likewise be committed to eradicating the structures that perpetuate inequality. As a result, we ought to find ways in which to preclude employers from making statistical judgments that greatly disadvantage women with at best minimal efficiency returns to employers.

\section{Men and Family Leave}

166 Christine Williams has argued that men benefit by preserving gender roles "because our society has traditionally rewarded masculine qualities more highly than feminine qualities. It avails men to monopolize masculine qualities, emphasize them in themselves, and enforce feminization on their female counterparts." WILLIAMS, supra note 117 , at 8-9. She concludes, "Men have historically used the occupational realm not only to secure economic advantages over women, but also to establish and affirm their essential difference from - and personal sense of superiority over - women." Id. at 133. See also Susan T. Fiske \& Peter Glick, Ambivalence \& Stereotypes Cause Sexual Harassment: A Theory With Implications for Organizational Change, $51 \mathrm{~J}$. OF SOCIAL ISSUES 97, 105 (1995) (arguing that "[t]he introduction of women into male-dominated jobs poses a threat to the gender-identity based self-esteem of men in these jobs.”).

167 See text and citations at note 152 . 
One way of doing so would be to find ways to encourage, or induce, men to take leave around the birth of their children, and ultimately to spend more time caring for their children. All of the issues so far discussed indicate that the best means of eradicating persistent labor market inequalities is to change the work patterns of men, rather than those of women, something that we have, to date, focused all too little on. The cumulative disadvantages women face are all directly tied to their greater devotion to their children, which is directly related to their lower pay, extreme job segregation, poorer advancement, and greater likelihood to miss work or drop out of the workforce to care for their children. Yet, despite frequent proclamations regarding their desire to spend more time with their families, men continue to work longer hours while maintaining their levels of housework and childcare. ${ }^{168}$ All studies indicate that few men avail themselves of family leave even when available, and the average length of the leave that is taken tends to be about five days. ${ }^{169}$

168 A study conducted by Families and Work Institute indicates that fathers were just as likely as mothers to indicate a willingness to trade salary for dependent assistance benefits. See Ellen Galinsky et al., The Role of Employers in Addressing the Needs of Employed Parents, 52 J. OF SoCIAL ISSUES 111, 119 (1996). Before the birth of a child, men and women generally express a commitment to shared child-care and housework. See D. N. Rubel et al., Change in the Marital Relationship During the Transition to FirstTime Motherhood: Effects of Violated Expectations Concerning Division of Household Labor, 55 J. OF PERSONALITY AND SOCIAL PSYCH. 78, 80 (1988). Polls likewise consistently demonstrate that women and men both feel they should spend more time with their children. See sources cited in note 13 supra; Richard Morin, With More Equity, More Sweat: Poll Shows Sexes Agree on Pros and Cons of New Roles, WASH. POST, Mar. 22, 1998, at A1 ("equally large majorities of working men and women said they ... wished they could devote more time to their families").

169 See Joseph Pleck, Are Family-Supportive Employer Policies Relevant to Men? in MEN WORK, \& FAMILY (J.C. HoOD ED., 1993) (finding through interviews that average leave for men was 5.3 days); Janet Shibley-Hyde, Women and Maternity Leave: Empirical Data and Policy, 19 PSYCH. OF WoMEN Q. 299, 307 (1995) (noting that average leave for men is about five days); Janet Shibley-Hyde et al., Fathers and Parental Leave: Attitudes and Experiences, 14 J. OF FAMILY IsSUES 616, 629 (1993) (finding a mean leave time of 5 days for surveyed fathers). 


\section{Family Leave and the Gender Wage Gap}

As the preceding discussion makes clear, if we can get men to shoulder more of the home burden, women's equality in the workplace will improve. ${ }^{170}$ Getting men to take more leave around the birth of their children will be an important but difficult task, and in section III I will explore ways in which we might be able to create incentives for men to take such leave. Currently, men proffer a great many excuses for why they do not take more leave, even though for at least the last twenty years men have continually expressed an interest in equal parenting and a desire to take parental leave. ${ }^{171}$ If there is anything universal in worldwide patterns relating to parental leave it is that men proclaim a much greater desire for leave than they appear willing to take. ${ }^{172}$

The most common reason men provide for why they cannot take more leave is that it would be economically infeasible for them to do so

170 Jacobsen \& Levin, supra note 83, at 18 (finding persistent and significant wage loss from extended leaves); Juhn \& Murphy, supra note 26, at 93 (noting the large negative effect the presence of children has on women's employment); David Shapiro \& Frank L. Mott, Long-Term Employment and Earnings of Women in Relation to Employment Behavior Surrounding the First Birth, 29 J. OF HUMAN RESOURCES 248, 272 (1994) (finding that consistent labor force attachment of women following childbirth resulted in wage premium of 19\%); Jane Waldfogel, Working Mothers Then and Now: A Cross-Cohort Analysis of the Effects of Maternity Leave on Women's Pay, in GENDER \& FAMILY ISSUES IN THE WORKPLACE 98 (F. Blau \& R. Ehrenberg eds., 1997) (finding that family status explains approximately fifty percent of the wage gap in 1991).

171 For example, in a 1978 poll, three quarters of the respondents, male and female alike, thought housework should be shared equally when both partners worked. See CROSBY, supra note164, at 148 (1991). In 1986, Working Woman magazine reported that "Nine in ten Americans today agree that it is important for fathers to spend as much time with their children as mothers do ..." How Working Women Have Changed America, Working Woman, Nov. 1986, at 134.

172 In a survey of recent books, sociologist Michael Kimmel observed, “A 1989 New York Times article is typical of the many work-family surveys conducted in recent years: in it, two-fifths of the fathers interviewed said they would quit their jobs if they could spend more time with their children. But the desire to change is often more rhetorical than real; few men would actually switch places with their nonworking wives if given the opportunity." Michael S. Kimmel, What do Men Want? HARVARD BusineSS REVIEW 50, 54 (Nov.-Dec. 1993) (footnote omitted). 


\section{Family Leave and the Gender Wage Gap}

given that they tend to have higher incomes than their wives and would therefore have to sacrifice more income if they were to take leave. ${ }^{173}$ But men's reluctance to take leave cannot be fully explained by their economic situation, as men with working wives appear far more capable of altering their behavior than they have done. While some economic sacrifices would be necessary to share the child rearing burden, taking leave at the birth of a child would certainly entail fewer costs or sacrifices, and whatever economic sacrifices might be necessary would likely only be short-term. In fact, taking leave would likely lead to greater wealth for most men. The reason it currently makes sense for women to sacrifice their income, to the extent it makes sense at all, is because they are paid less than men, but the primary reason they are paid less than men is that they have the primary responsibility for child rearing. ${ }^{174}$ If that cycle were broken, women's earnings would likely rise by as much as twenty percent, and as long as men's income did not suffer a similar decline, overall wealth would increase. Surely, it can be no argument to prefer men's higher incomes at the expense of women's income, and the only way this vicious cycle can be derailed is for something to give, and that must be men's current advantage.

That said, it is not at all clear that significant economic sacrifices would be necessary for more men to take longer leaves. Nearly one quarter of women now earn more than their husbands reflecting a substantial increase during the last decade, ${ }^{175}$ and approximately one-

173 See Hyde et al., supra note 169, at 635 (identifying "economic necessity" as a reason why men do not take more leave); Martin H. Malin, Fathers and Parental Leave, 72 TEX. L. REV. 1047, 1065 (1994) ("The father's primary role in providing economic security functions as a barrier to increased parental involvement in the family.").

174 See Becker, supra note 77, at 937 (noting the vicious circle that subordinates women by paying them less and thus increasing the attractiveness of their nonmarket opportunities).

175 See Ann E. Winkler, Earnings of Husbands and Wives in Dual Earner Families, 121 MONTHLY LABOR REVIEW 8, 10 (1998) ("Data from the Current Population Survey (CPS) show that the proportion of dual-earner couples in which wives earned more than their husbands increased from 16 percent in 1981 to 23 percent in 


\section{Family Leave and the Gender Wage Gap}

third of married women between the ages of 25 and 34 have rough wage parity with their husbands. ${ }^{176}$ These two facts suggest that a substantial number of men could take family leave that approximates the leave of their wives without making economic sacrifices, and a quarter of married men should be taking longer leaves than their wives if economics were truly driving the decision. ${ }^{177}$ Although men often claim they do not have access to leave, studies indicate that parental leave is available to men at a far higher rate than their utilization rates would indicate. Between 18 to 36 percent of surveyed employers offered parental leave to men even before the FMLA was implemented. ${ }^{178}$ Often times the leave was unpaid, as was also true for the leave offered to women, but men also have access to their vacation and in some instances sick leave and as many women do, they could save up their vacation in anticipation of the birth of a child.

Another reason men offer for their inability to take leave is that

1996.”).

176 See Blau, supra note 41 at 149 . As noted earlier, wage disparities tend to increase over time and women tend to begin their careers in at greater salary parity with men. See supra note 96.

177 One indication that economics is certainly not the only factor at work is that very few families even consider the option of having the man stay home or alter his work hours. In her study of equal parenting families, Francine Deutsch observed, "[A] taken for granted quality of inequality with respect to paid work is common among ... families [with unequal parenting], even ones where the women had high-powered professions. When I asked why it was the mother who cut back to part-time work in many of these families, the question didn't seem to make sense to them. That the father could be the one to stay home had never been discussed or even given a moment's thought." DEUTSCH, supra note, at 58 .

178 See Malin, supra note 177, at 1071 (citing studies). Prior to the passage of the FMLA, a higher percentage of employers made leave available to their female employees than to their male employees, but the numbers were not drastically different. Citing a study by the Catalyst organization released in 1986, Malin reports that $37 \%$ of employers offered parental leave to fathers while $52 \%$ offered such leave to mothers. Id. 


\section{Family Leave and the Gender Wage Gap}

they fear they will suffer workplace repercussions from their employers. ${ }^{179}$ This may or may not be true but should not be given undue weight. ${ }^{180}$ As discussed extensively above, women currently face substantial penalties for taking leave, and again, it cannot be argued that men, but only men, should be spared workplace repercussions when they take leave. Given the existing workplace norms, there is some evidence that men suffer greater penalties for taking leave than women do since their leave taking violates the prevailing gender norms. ${ }^{181}$ However, currently employers are able to exact stiff penalties against men because so few men take leave. If a greater number of men were to take leave, it is unlikely that employers could persist in retaliating against their employees, as the norm of leave taking would shift to render those who take leave the norm rather than the exception. After all, employers cannot penalize all of their employees, and if they do so in the form of lower salaries, then it would be appropriate to view that as a cost the employees are willing to pay, just as they pay for other workplace benefits, rather than a penalty employers exact on a few nonconforming employees.

In addition to the economic considerations, gender norms are

${ }^{179} I d$. at 1077 (discussing perceived employer hostility to men taking leave); Janet Sibley-Hyde et al., supra note 169, 629 (23\% of surveyed men thought their supervisors would be supportive of leave while $63 \%$ thought supervisor would respond negatively).

180 Given that so few men take leave, the evidence of actual retribution is purely speculative. A contrasting view was recently presented in a study of Norwegian fathers who took leave, one of the few studies of its kind. Although the study involved a limited sample, the authors found that the men who took leave were "admired by their colleagues and their friends" and did not appear to experience adverse consequences from their employers. See Berit Brandth \& Elin Kvande, Masculinity \& Child Care: The Reconstruction of Fathering, 46 SOCIOLOGICAL RVw. 293, 309-10 (1998).

181 See Alison M. Konrad \& Kathy Cannings, The Effects of Gender Role Congruence and Statistical Discrimination on Managerial Advancement, 50 HUMAN RELATIONS 1305, 1318-19 (1997) (finding that men were rewarded more for long hours and penalized more than women for their attention to household duties). Men also appear to be penalized more than women for working part-time. See Marianne A. Ferber \& Jane Waldfogel, The Long-Term Consequences of Nontraditional Employment, 121 MONTHLY LABOR REV. 3,5 (1998). 
certainly playing a role, as child rearing continues to be seen as women's work and the notion of taking leave to care for a newborn may threaten the existing roles. ${ }^{182}$ These issues will have to be challenged if we are to make greater progress toward workplace equality. To make more progress, it will be necessary to find ways to get men to take more leave, although we should also realize that men are unlikely to do so voluntarily and will require some greater incentives than currently exist to break up the existing patterns. In the next section, I will discuss why the FMLA is unlikely to contribute to disrupting the existing gender roles, and I will then explore ways in which family leave might be altered so as to create the conditions for greater workplace equality.

\section{THE FAMILY MEDICAL LEAVE ACT \& GENDER STEREOTYPES.}

The Family and Medical Leave Act (hereafter "the FMLA" or "the Act") was intended to ameliorate some of the difficulties parents encounter in balancing work and family commitments, and it remains the only federal law intended to aid workers in having and raising children. In this section, I will explore the effects the FMLA has had to date and argue that the Act has made a minimal actual difference for working parents; indeed, I will suggest that to the extent it has made a difference, it has been to reinforce existing gender inequalities in the workplace. Given the experience in other countries and states that offer more generous leave, I also conclude that drastic measures are necessary in order to facilitate men actually taking leave, and that moving to a system of paid leave, by itself, will likely be insufficient to chip away at the prevailing gender norms that help perpetuate workplace inequality.

\section{A. The FAmily Medical Leave ACT.}

182 Joseph Pleck argues, "For most men, taking . . . leave is not part of their conception of their role as father. Unlike mothers, fathers have not grown up believing there is a special bond between themselves and their child that requires their being home full-time during the first months of their child's life." Pleck, supra note 169, at 230. 


\section{A Statutory Overview.}

The FMLA was passed in 1993 to great fanfare ${ }^{183}$ making the United States one of the last industrial nations to adopt a leave law, although as discussed in more detail below the American law is among the least generous of any existing legislation. ${ }^{184}$ As a symbolic gesture, President Clinton signed the Act into law as his first official legislative act, marking the end of a five-year effort to implement a federal leave law, a process that included two vetoes by President George Bush but which ended up failing to rise much beyond the symbolic level. ${ }^{185}$

The FMLA provides twelve weeks of unpaid leave to employees working for employers having fifty or more employees. In order to be eligible for the leave, the employee must have worked for the employer for at least one year, and worked for that employer at least 1,250 hours during the previous twelve months. ${ }^{186}$ Despite these restrictions, it is estimated that the Act covers approximately sixty percent of the nation's private sector workforce, even though only about eleven percent of the nation's employers are covered. ${ }^{187}$ Public employers are also bound by

183 Upon passage, the bill received wide acclaim upon its passage. See, e.g., Editorial, A Victory for Families, ST. LouIS Post-DisPATCH, Feb. 6, 1993, at 2B; Carl Leubsdorf, Clinton Signs Bill for Family Leave in Jubilant Ceremony, DALLAS MORNING NEWs, Feb. 6, 1993, at 3A; Elizabeth Neuffer, Leave Bill OK'D: Clinton to Sign Today, Boston Globe, Feb. 5, 1993, at 1; Paul Richter \& Gebe Martinez, Clinton Signs Family Leave Bill Into Law: President Marks First Victory, Los ANGELES TiMES, Feb. 6, 1993, at A22; ; Janice Turner, U.S. Family Leave Plan Wins Praise in Canada, TORONTO STAR, Feb. 6, 1993, at A1.

184 See supra note 7; StePhanie CoOnTZ, The Way We ReAlly Are 73 (1997) ("The United States shares with South Africa the distinction of being the only two developed economies without a national insurance program for families").

185 For a thorough discussion of the road to passage see RONALD D. ELVING, CONFLICT \& COMPROMISE (1995).

18629 U.S.C. § 2611(2)(A)(i).

187 COMmission on FAMILY ANd MEdial LEAVE, A Workable BalanCE: REPORT TO CONGRESS ON FAMILY AND MEDICAL LEAVE PRACTICES at 58-61 (1997) 
the statutory provisions, which total number of covered employees to 66 percent of the workforce, with approximately 55 percent of employees statutorily eligible to take leave. ${ }^{188}$

Under the terms of the statute, leave is available to an employee to care for a newborn, newly-adopted or foster child, for one's own serious illness, as well as to care for a seriously ill spouse, parent or child. ${ }^{189}$ The statute also provides for job-protection in the form of a guarantee that at the end of the leave the employee will be returned to the same or substantially equivalent position, with some limited exceptions. ${ }^{190}$ Importantly, the leave is unpaid, and the employer can require that an employee utilize her accumulated vacation or sick leave prior to taking the statutory leave to care for a new child that has been brought into the family. ${ }^{191}$

\section{The Effect of the FMLA.}

In order to assess the effect and importance of the FMLA, it is necessary to first know what kind of leave was generally available before the Act was passed. This task is made somewhat difficult because where provided, maternity leave was typically not offered through formal

(hereafter "A WORKABLE BALANCE"). Of the covered employees, approximately $46.5 \%$ have met the statutory requirements rendering them eligible to take leave. $I d$. at 60 .

188 Id. at 61.

18929 U.S.C. $\S 2612(a)(1)$.

19029 U.S.C. $\$ 2614(a)(1)$. The statute exempts from this requirement those who are paid among the top ten percent of the workforce if restoring them would cause "substantial and grievous economic harm." 29 U.S.C. § 2614 (b). It is also not necessary to restore a worker to a position that would have been eliminated if the person had not been on leave.

19129 U.S.C. § 2612(d)(2)(A). Another important aspect of the legislation is that an employer must continue to provide health benefits during the leave, which the employee can be required to repay should the employee fail to return to work from her leave. Id. at $\S 2614(c)(1)$. 


\section{Family Leave and the Gender Wage Gap}

"maternity leave" policies but instead was afforded in various other ways, such as through sick leave or disability policies, or informal leave, which made it difficult to know who had access to what kind of leave. ${ }^{192}$ The federal government, however, periodically surveys employers to determine the kind and form of benefits they provide to employees. These estimates suggested that a majority of large employers, defined as those employing more than 100 employees, provided some form of leave that would enable women, but not necessarily men, to take time off around the birth of a child. Paid sick leave was the most common form of leave available, and unpaid maternity leave was also provided by a substantial segment of employers. ${ }^{193}$ Nearly ninety percent of full-time employees of large firms also had access to disability plans that included coverage for

192 For a discussion of the variety of plans see Olivia S. Mitchell, Work and Family Benefits, at 270-71, in GENDER AND FAMILY ISSUES IN THE WORKPLACE (Francine D. Blau \& Ronald G. Ehrenberg, eds., 1997). Another reason it was often difficult to assess the availability of leave is that many of the studies were conducted by advocacy groups intent on influencing the legislation. Not surprisingly, employersponsored studies tended to suggest inflated levels of coverage, as well as what have proved to be grossly inflated estimates of the cost of extending leave, while employeesponsored studies indicated a paucity of benefits, and likewise typically underestimated the costs of additional leave legislation. For example, the National Association of Wholesalers survey, conducted in 1990 in the midst of the legislative battle, found that $54 \%$ of their members offered leave comparable to FMLA leave, a high estimate considering that twothirds of the surveyed employers employed under 50 employees. See National ASSOCIATION OF WHOLESALERS, EMPLOYEE BENEFITS SURVEY (1990). In perhaps the most well-known study, the Chamber of Commerce estimated compliance with the FMLA would cost approximately $\$ 13$ billion a year. See Michelle Rose Marks, Party Politics and Family Policy: The Case of the Family and Medical Leave Act, 18 J. OF FAMILY ISSUES 55, 59 (1997) (discussing the study and its influence). An employee-sponsored survey, on the other hand, found that there would be no increase in cost for more than two thirds of employers when it came to training, health insurance or unemployment insurance, and no administrative costs reported by more than half of employers. See JOHN T. BOND ET AL., Beyond the PARENTAl LeAVE Debate: The IMPACt OF LAWS IN Four States, at iii (1991). The employee-sponsored survey turned out to offer the most accurate prediction. See infra notes 209-10.

193 Some of the data is difficult to interpret because it surveyed employers of all sizes. See U.S. DePt. Of Labor, Bureau of Labor Statistics, EMPloyeE BenEFits SURVEY (1993). 


\section{Family Leave and the Gender Wage Gap}

pregnancy, ${ }^{194}$ as did ninety-six percent of state and local employees. ${ }^{195}$ As the figures indicate, large employers were far more likely to offer leave than smaller employers, and professional employees tended to have better access to leave than clerical employees. ${ }^{196}$ Those who had worked for medium to large-size employers for at least five years were estimated to have benefits that averaged about nine weeks of of available leave at full pay. ${ }^{197}$

In addition to the availability of employer-provided leave, at the time the FMLA was enacted, thirty-four states, as well as Puerto Rico and Washington, D.C., had some type of leave legislation in place. The state statutes varied in their provisions -- some offering more generous protection than was ultimately enacted by the FMLA while others offered less -- and five states made some form of wage replacement available through temporary disability insurance laws. ${ }^{198}$ A number of studies

194 See Jane Waldfogel, supra note 170, at 94 (citing government statistics).

195 See Christopher J. Ruhm, The Family and Medical Leave Act, 11 J. OF ECON. PERSPECTIVES 175, 182 (1997).

196 See Issacharoff \& Rosenblum, supra note 130, at 2190 ("The smaller firms that are not covered by the [FMLA] are the ones that are least likely to offer such benefits currently."); Shelley M. MacDermid et al., Organizational Size and Work-Family Issues, 111, 120, in THE EVOlving WORLD OF WORK AND FAMILY: NEW STAKEHOLDERS, NEW VOICES (Marcie Pitts-Catsouples \& Bradley K. Gougins eds. 1992) (noting that large firms offer more benefits and are more willing to accommodate flexible work practices, particularly for professional employees).

197 See Jutta M. Joesch, Paid Leave and the Timing of Women's Employment Before and After Birth, 59 J. OF MARRIAGE \& FAMILY 1008, 1009-10 (1997) (finding 61 days of paid leave were available for those who had at least five years of tenure with their employer). For a discussion of the status of leave prior to the passage of the FMLA see U. S. DePt. OF LABOR, EMPLOYEE BENEFITS IN MEDIUM to LARGE FirMS 1989, at 2 (Bulletin No. 2363 1990). .

198 The laws are described in more detail in WOMEN's LEGAL DEFENSE FUND, STATE LAW AND REgUlations GUARANTEEING EMPLOYEES THEIR JOBS AFTER FAMILY AND MEdiCAl LEAVES (1993), U.S. DEPARTMENT OF LABOR, STATE MATERNITY/FAMILY LEAVE LAW (1993), and are discussed in A WORKABLE BALANCE, supra note 187, at 4449. 


\section{Family Leave and the Gender Wage Gap}

sought to measure the extent the leave laws were utilized, and all of the studies indicated very low utilization rates, typically from one to three percent of employees annually. ${ }^{199}$

\section{B. The FMLA in Action.}

\section{The Use of the FMLA.}

Analyzing the pre-existing law in this detail helps expose the benefits the FMLA actually provided, and places the law in proper perspective. Recent data confirm that the FMLA provided employees with little more than was previously available, with the largely unintended exception of providing some additional unpaid sick leave to employees. ${ }^{200}$ Although the statute is still young, the Commission on Family and Medical Leave recently commissioned two comprehensive studies to determine the use and cost of the FMLA, and those studies offer important and revealing insights into the Act. ${ }^{201}$ The surveys sought to

199 See EILEEN TrZCinski \& William T. AlPERT, LEAVE POLICIES IN SMALL BUSINESS: FINDINGS FROM THE SMALL BUSINESS ADMINISTRATION EMPLOYEE LEAVE SuRVEY (1990); Eileen Trzcinski \& M.Finn Stevenson, A Response to Arguments Against Parental Leave: Findings From the Connecticut Survey of Parental Leave Policies, $52 \mathrm{~J}$. OF MARRIAGE \& FAMILY 445 (1992); TOWERS PERRIN, INC., FAMILY AND MEDICAL LEAVE Programs: Before AND AFTER THE NEW FEDERAL LAW (1993).

200 See Suzanne M. Crampton \& Jitendra M. Mishra, Family and Medical Leave Legislation: Organizational Policies and Strategies, 24 PubliC Personnel MGT. 271, 274 (1995) (noting that "the number of companies with some type of leave policy already in place prior to the passage of the FMLA has been estimated to be up to 89 percent . .."); Marks, supra note 192, at 65 (noting that " $[\mathrm{t}]$ he final bill demanded nothing more of most businesses . . than what they provided already.").

201 One survey concentrated on a random sample of private employers, while the other sampled a random group of employees from both the public and private sector. The Employer Survey, conducted by Westat sampled a national, random group of employers, interviewing respondents from 1,206 worksites. See A WORKABLE BALANCE, supra note 187, at 23. The Employee Survey, conducted by the University of Michigan Survey Research Center, targeted employees aged 18 and over who lived in the United States, and had been employed for pay any time within the last 18 months between January 1, 1994 to the Summer of 1995 when the survey was conducted. Id. at 24. 


\section{Family Leave and the Gender Wage Gap}

determine how employers and employees had responded to the passage of the Act, as well as measuring to the extent practicable its accompanying costs and benefits, and these studies highlight the limitations of the FMLA.

Both surveys found relatively low utilization rates of FMLA benefits, levels that were consistent with previous studies. The employer survey indicated that 3.6 out of every 100 employees at private-sector worksites took some form of FMLA leave, while the employee survey found a utilization rate of 2 percent. ${ }^{202}$ Although the rates may appear low, in absolute numbers they represent as many as 2.5 million employees who took FMLA leave during the 18 months of the survey. Equally important, these numbers represent those who took leave under the Act, a far larger number of employees took leave for a reason covered by the FMLA but only a small fraction (7 percent in the employee survey) took leave formally under the FMLA, as most employees continued to utilize other forms of available leave, such as their sick leave or disability insurance. ${ }^{203}$

The surveys also collected data on who took leave for what reason. Women took significantly more leave than men (58.2\% compared to $41.8 \%$ ), and the largest group of leave takers fell into the age group of between 35 and 49 years old. ${ }^{204}$ This latter fact suggests that much of the leave was not likely related to the birth or adoption of a child, a fact that was confirmed by the survey results. Indeed, nearly sixty percent of those who took leave did so for their own health related problem, and only 17.1

${ }^{202} I d$. at 83. There is some indication that employer compliance with the FMLA was limited immediately following its passage which could suppress the number of individuals who took leave. See Sue Shellenbarger, Many Employers Flout Family \& Medical Leave Law, WALL STREET J., July 26, 1994, at B1 (reporting that one study found that up to $40 \%$ of employers failed to provide required leave).

203 The Employee Survey found that $16.8 \%$ of employees surveyed took leave for a reason covered by the FMLA but only $7 \%$ of that group took leave under the FMLA. See A WorkABLE BALANCE, supra note 187 , at 84.

${ }^{204}$ Id. at 92. 


\section{Family Leave and the Gender Wage Gap}

percent took leave for reasons related to the birth or adoption of a child..$^{205}$

The studies found no significant difference between men and women on the rate or length of taking parental leave, ${ }^{206}$ and the median length of leave was ten days, though there was substantial variance among the leave takers. Seventy-five percent of those who took leave returned within 35 days, and about twelve percent of employees of covered sites took more than twelve weeks of. ${ }^{207}$ Somewhat surprisingly, a significant portion of FMLA leave to care for newborns lasted less than one week, although leave defined as "maternity-leave" tended to last substantially longer. ${ }^{208}$

Finally, the surveys suggested the costs of the FMLA to employers appear to be quite modest. More than two-thirds of employers covered the employee out on leave with other employees, and the employees who were replaced by a permanent hire tended to fall into the

${ }^{205} I d$. at 94. Somewhat ironically, the employee survey found a higher level of leave related to child birth or adoption in worksites that were not covered by the FMLA, which accounted for approximately $21 \%$ of the FMLA related leave. Id.

206 Id. at $95-96$.

207 Id. at 97 . The vast majority of employees returned to work following their leave, with approximately $5.6 \%$ of all leave-takers failing to return. Id. at 113 .

208 Thirty-seven percent of those who took leave to care for a newborn returned to work within seven days. Id. at 97 . In contrast, $42.4 \%$ of maternity-disability leave lasted at least twelve weeks. Id. at 269, Table 5.D. There was also a small group of individuals who indicated that they were unable to take FMLA leave despite their need for the leave. Just under four percent of the surveyed employees indicated that they needed leave but did not take it, with nearly two-thirds of those employees indicating they did not take leave because they could not afford to. Id. at 98-99. Significantly, less than ten percent of the needed but untaken leave was related to the birth or adoption of a child, as most of the untaken leave was to care for a sick child or parent or for one's own health problem. Id. at 99 . 
lowest income category. ${ }^{209}$ Interestingly, more employers indicated that the benefits of the Act, in terms of increased productivity, outweighed whatever costs they incurred. ${ }^{210}$

\section{Evaluating the Effect of the Statute.}

Based on this early survey data, it appears that the FMLA has had its greatest impact by allowing employees to take unpaid sick leave for a limited time, leave that may not have been available without the legislation. In some ways, this finding should come as little surprise, as with respect to leave relating to the birth or adoption of a child, the Act largely replicated what the market was already providing - unpaid leave to those who worked for large employees. ${ }^{211}$ Certainly there is no indication that the FMLA has greatly, or even mildly, facilitated the balancing of work and family commitments, nor is there any evidence that it has induced men to play a greater role at the birth or adoption of a child, especially given how very short the leaves tend to be. The surveys also suggest that most people who are taking substantial amounts of leave are doing so under non-FMLA provided policies: nearly fifty percent of employees reported receiving full wage replacement for the leave, while another twenty percent indicated receiving partial pay, neither of which is required by the Act. ${ }^{212}$

209 Id. at $102-03$.

${ }^{210} I d$. at 131, Figure 6.4 Somewhat paradoxically given the exemption for employers with fewer than 50 employees, nearly twice as many larger employers reported moderate or large cost effects than smaller employers. Id. at 126.

211 See Marks, supra note 192, at 65 (noting that the bill offered little more than most business provided); Ruhm, supra note 195, at 177 (finding that the FMLA primarily symbolic). Ruth Colker recently lamented, "[The] only solace [for low-income workers] is that, if they work for a large employer, they, at least, will have a job to which they can return after taking the most minimal possible medical leave." Ruth Colker, Pregnancy, Parenting, and Capitalism, 58 OHIO ST. L.J. 61, 62 (1997);

212 See A WorkABLE BALANCE, supra note 187, at 107 (reporting that $46.7 \%$ of employees reported receiving full wage replacement and $19.6 \%$ received partial pay). 
The fact that the FMLA largely replicates what employers were already providing raises the question why the Act was seen as so critically important to the workplace, and why its advocates were willing to settle for such a weak form of parental leave. One participant in the battle to enact the FMLA, while acknowledging its limitations, suggested that advocacy groups persevered under the theory that some legislation was better than no legislation. ${ }^{213}$ As a statement reflecting the interests of the advocacy groups, this very well may have been true and may have made for a sound decision as their legislative achievements could later be touted to their constituencies. ${ }^{214}$ The statute symbolic significance representing first federal legislation addressing family leave - should also not be overlooked in evaluating the merits of the Act.

But symbolic legislation garners little more than symbolic relief, and may carry with it significant negative effects. It is far from clear that the interests of women in the workplace would be furthered better by any legislation, including that which was ultimately passed, than by no legislation given the potential for what might be termed significant negative externalities from the legislation. One of the dangers associated with passing a weak bill is that once federal legislation is enacted, family leave legislation may removed as items of importance for state legislatures or unions, which may have provided more hospitable venues for significant reform than the ineffectual federal law. Indeed, this seems to have occurred. Since the passage of the FMLA, no significant state legislation

${ }^{213}$ Katherine Karr Kaitin quotes advocates for the FMLA as noting the political reality against paid leave and asking, "[S]hould we have done nothing or should we have gone with unpaid leave?" Kaitin concludes, "The coalition members did choose to do something, believing that any leave was better than none at all." Katherine Karr Kaitin, Congressional Response to Families in the Workplace: The Family Medical Leave Act of 1987-88, at 105, in More THAN KISSING BABIES? (Francine H. Jacobs \& Margery W. Davies, eds. 1994). See also Anya Bernstein, Inside or Outside? The Politics of Family and Medical Leave, 25 PoliCY STUDIES J. 87, 90 (1997) (quoting one of the legislation's proponents as suggesting that "half a loaf is better than none.").

214 See Bernstein, supra note 213 at 91 (arguing that interest groups are often motivated by what the author labels "credit-claiming" incentives). 


\section{Family Leave and the Gender Wage Gap}

has been enacted, ${ }^{215}$ and the only federal efforts have been to expand the Act to include unpaid leave for such things as parent-teacher meetings and efforts to extend the Act to smaller employers. ${ }^{216}$ These are both worthy goals but surely limited in their aspirations, and there has been no discussion of moving toward guaranteeing paid leave. ${ }^{217}$

The legislation may also have preempted the development of more friendly policies in the private sector. Prior to the passage of the FMLA, there appeared to be a modest trend by private employers to provide increasingly generous paid leave policies, a trend that now seems to have stalled as the federal legislation has become the ceiling of benefits. ${ }^{218}$ The only positive note in the aftermath of the legislation is that unions appear to be seeking greater leave benefits in their collective bargaining efforts and publicizing their efforts as a way to attract new

215 The Daily Labor Report publishes an annual listing of all significant state labor legislation enacted during the previous year, and a review of the each list published since 1993 indicates that there has been no significant new legislation. Several states have amended their leave legislation to permit parents to attend parent-teacher conferences, though not even all of that rather limited legislation has been successfully passed. See Maine Governor Vetoes Minimum Wage Hike, Expanded Family Leave, Higher Comp Levels, DAILY LABOR RPT., June 17, 1999, at A-10 (describing veto of legislation to allow parents 24 hours to care for children or attend parent-teacher conferences).

216 See Bernstein, supra note 213, at 97 (describing proposals).

217 The President recently has suggested that states should be allowed to use unemployment surpluses to subsidize family leave, an idea that would provide some wage replacement, though at the low levels currently available for the unemployed, and would likely provide some benefit to those who currently do not have access to paid leave. See John M. Broder, Clinton Proposes Using Surpluses to Extend Family Leave Benefits, N. Y. TiMES, May 24, 1999, at A4. The President's suggestion came in a graduation speech in a time of historically low unemployment levels and it is too early to tell whether this traditional day of optimism will bear fruit.

${ }^{218}$ It is easy to see how this preclusive effect can occur. Employers tend to offer generous benefits as a way of attracting employees and maintaining a competitive edge in the labor market. However, once the law creates a federal right, that right can become what employees expect, and therefore employers may be less likely to use leave as a means to attract employees. Better data will be necessary, however, before we can determine whether this is what in fact has occurred. 
members. ${ }^{219}$

The early experience with the FMLA, as well as the substantial limitations of the existing statute, definitively suggests that something more needs to be done. This is especially true if the goal is to encourage more men to take parental leave, a goal the current statute is inadequately structured to address. In the next section, I will discuss several ways in which the statute might be amended in order to create more gender equality in the workplace, though it will be important to first discuss some of the proposals that have been offered to address the persistent problems.

\section{BRINGING EQUALITY TO THE WORKPLACE.}

Creating a successful national family leave policy remains the key to reducing workplace inequality for women. As discussed in more detail below, there are a number of ways in which the statute might be amended with an aim toward breaking up the gendered divisions that continue to demarcate both work and home lives. Before discussing these proposals, however, I want to spend some time analyzing a recent tax reform proposal that is largely intended to address the same problem I have been discussing in this article - namely, the persistence of gender inequality in the workplace.

\section{A. The Idea of Tax Reform.}

As previously noted, it is often suggested that it is economically rational for women to leave the labor force when they have children, and that, economic considerations primarily determine that decision. ${ }^{220}$ In his engaging recent book, Taxing Women, Edward McCaffery argues that women leave the workforce because the tax system, along with their

219 The AFL-CIO includes a section on their web page pronouncing their success in bargaining for greater leave. See Bargaining to Expand the Family and Medical Leave Act, which can be found at http://www.aflcio.org/women/fsbargain.htm.

${ }^{220}$ See supra note 137. 


\section{Family Leave and the Gender Wage Gap}

lower incomes when compared to men, compels them to forego their market wage in order to care for their children. ${ }^{221}$ His primary concern is with the system of joint tax filing, which he contends imposes penalties on secondary income earners, a phenomenon that disproportionately affects women given that women tend to earn less than their husbands. ${ }^{222}$ McCaffery therefore proposes that the tax system be restructured to tax married women at a lower rate than others in order to create sufficient incentives to encourage more women to enter, or remain in, the labor force. $^{223}$

This is an intriguing idea, and McCaffery deserves much credit for having sparked a lively debate regarding the gendered nature of the tax system. ${ }^{224}$ It is far less certain, however, that his proposal would produce the results he suggests, for at least two reasons. First, his theory is premised on a weak empirical foundation. The essence of McCaffery's argument is that women's labor force attachment is quite elastic relative to wages, whereas men's attachment is inelastic and he bases his assumption on several older studies. ${ }^{225}$ More recent empirical work casts doubt on this critical assumption, as it appears that the elasticity of women's labor force attachment is increasingly becoming more like

${ }^{221}$ EDWARD J. MCCAFFERY, TAXING WOMEN (1997) (hereafter TAXING WOMEN). McCaffery's book is primarily based on two articles that previously appeared in law reviews, Edward J. McCaffery, Slouching Towards Equality: Gender Discrimination, Market Efficiency, and Social Change, 103 YALE L.J. 595 (1993); Taxation and the Family: A Fresh Look at Behavioral Gender Bias in the Code, 40 UCLA L. REV. 983 (1993).

222 MCCAFFERY, TAXING WOMEN, supra note 221, at 137-60 \& 178-82.

${ }^{223} I d$. at $276-80$.

${ }^{224}$ For recent commentaries on McCaffery's argument see Anne L. Alstott, Tax Policy \& Feminism: Competing Goals \& Institutional Choices, 96 COLUM. L. REV. 2002, 2018-19 (1996); Lawrence Zelenak, Tax and the Married Woman, 70 SOUTHERN CALIF. L. REV. 1021 (1997).

225 MCCAFFERY, TAXING WOMEN, supra note 221, at 179-82. Most of the studies McCaffery relies on interpret data from the mid-1980s or earlier. Id. 


\section{Family Leave and the Gender Wage Gap}

men's. ${ }^{226}$ Recent data also indicates that the women whose husband's have high incomes are entering the workforce at a faster rate than those at the bottom of the scale, a fact that is difficult to reconcile with McCaffery's theory. ${ }^{27}$

Relatedly, McCaffery fails to provide supporting data for his argument that it is cost effective for women to stay at home to care for their children. Taxes unquestionably eat away at secondary incomes, but it would only make financial sense for women to leave the workforce if their net pay was so low as either not to cover expenses such as childcare, or sufficiently low to satisfy the worker's preference for nonwork. Neither assumption has been empirically established. Jane Waldfogel has recently calculated that child care costs average approximately 22 percent of female earnings, leaving substantial income even after accounting for taxes. ${ }^{228}$ McCaffery would likely respond by suggesting that the elasticity

${ }^{226}$ For example, in their study of working women, Klerman and Leibowitz concluded that higher wages did not increase the number of women who returned to work. The authors concluded, "There is little support for the hypothesis that higher wages induce women to return to work sooner after giving birth than do lower wages." Klerman \& Leibowitz, supra note 84, at 289. The authors did find that higher wage women were significantly more likely to be on leave, although that leave was also likely to be unpaid. Id. at 294. Another recent study found that women's elasticity is much lower than had originally been documented, and depends greatly upon the presence and number of children as well as the education level of the woman. See Juhn \& Murphy, supra note, 26, at 86-92 . See also Alstott, supra note 224, at 2018-19 (critiquing studies documenting increased female labor supply in response to increased wages).

227 See RoBERT MAX JACKSON, DESTINED FOR EQUALITY: THE INEVITABLE RISE OF WOMEN's STATUS 97 (1998) ("The primary trend of wives joining the work force has been overwhelmingly independent of husband's economic status.”); Maria Cancian, Sheldon Danziger \& Peter Gottschalk, Working Wives \& Family Income Inequality Among Married Couples, in UnEVEN TIDES: RISING INEQUALITY IN AMERICA 198 \& Table 6.1 (S. Danziger \& P. Gottschalk eds. 1993) (between 1968 and 1988 the largest group of white women entering the workforce were those married to high income men); Juhn \& Murphy, supra note 26, at 89 (women's employment increased most dramatically at upper income ranges).

228 Jane Waldfogel, supra note 7,at 141. Amy Christian has recently suggested that a woman earning $\$ 30,000$ would likely have a net loss of income when expenses are 


\section{Family Leave and the Gender Wage Gap}

of women's decision to work suggests that the decision is not entirely determined by the economic feasibility of staying home, but again, without more support for the underlying claim of elasticity this response fails to overcome the empirical objections.

Additionally, embedded within McCaffery's analysis is the vice identified earlier, namely that the choice to sacrifice a woman's income is economically rational and should be treated as such. It is important to highlight the circularity of this position: the primary reason a woman's income is lower than men's is that she is expected to leave the workforce to care for children, and fulfilling that expectation is the best way to ensure that the gender income inequality persists. Even if the strategy makes sense on an individual family level, it may reduce our social welfare by suppressing the wages of women, which may provide a strong argument for governmental action to alter the existing patterns. Indeed, changing the work patterns of men would seem preferable to adopting the controversial, and constitutionally arousing, ${ }^{229}$ change in the tax code, particularly given the empirical limitations of the theory.

\section{B. Fixing FMLA with an Eye on Equality.}

In this section I want to discuss several ways in which the FMLA might be altered so as to alleviate some of the workplace disadvantage

accounted for, suggesting that it is economically rational for most women to remain at home. See Amy C. Christian, The Joint Return Rate Structure: Identifying and Addressing the Gendered Nature of the Tax Law, 13 J. OF LAW \& POLITICS 241, 289-92 (1997). However, Christian's costs estimates are grossly inflated calculations she never actually seeks to document. More to the point, Christian's argument is plainly refuted by the presence of millions of working mothers in the workforce who earn less than $\$ 30,000$, surely an indication that they are not losing money by working.

${ }^{229}$ It is somewhat surprising that neither McCaffery nor those who have commented on his proposal discuss its constitutionality. Creating an explicitly gender based tax system would certainly be subject to a constitutional challenge that would have to meet the intermediate level of scrutiny. As I discuss below, I believe an argument can be made supporting the constitutionality of a similar program but it is not something that ought to be assumed. See note 242 infra. 


\section{Family Leave and the Gender Wage Gap}

women continue to experience, and to help change the governing norms. However, rather than provide detailed policy proposals, I want to treat this section as more tentative and exploratory as a way of beginning a conversation. This seems to make sense not only because some of the proposals likely have little chance of being adopted in the near future but also because amending the FMLA should be seen as only one facet of a more comprehensive reform strategy. Surely at this stage of our experience, it would be foolish to think there is any single or easy fix to what is an enormously complicated and deep-seated problem.

\section{The Need for Paid Leave.}

There are various ways in which a more equitable family leave system might be obtained but all of them will require some form of paid leave. Ideally, the twelve weeks of currently mandated unpaid leave would be transformed into paid leave, but if that proves infeasible, at least in the short term, then a minimum of six weeks of paid leave for men and women following the birth or adoption of the child should be made available. As a way of equalizing leave taking to some degree, it should be mandated that leave be taken in its entirety or not at all. In other words, a parent would have to take the full six weeks in order to receive any paid leave, and the leave would belong exclusively to one parent without the possibility of sharing the leave between parents. ${ }^{230}$ If this policy were adopted, consistent with the existing mandate, six additional weeks of unpaid leave should also be made available to parents.

Providing six weeks of paid leave should induce some fathers to take parental leave, perhaps as many as twenty percent. ${ }^{231}$ Additionally,

\footnotetext{
${ }^{230}$ A number of countries have allowed parents to share a specified amount of leave, but when they do so mothers utilize the vast majority of the leave time. See SANDRA FRIEDMAN, WOMEN AND THE LAW 219-20 (1997) (discussing limits of shared leave).

231 This seems to be an upward estimate based on experiences within Sweden and American companies where leave has been encouraged. Professor Malin seems to suggest that the numbers could be even higher, though his rationalizations for why men do not currently take leave accumulate to a point beyond credibility. It seems incredible, for
} 


\section{Family Leave and the Gender Wage Gap}

and not insignificantly, it may help settle the question of whether men actually want to be involved more directly in child rearing, as their current excuses for not taking leave would be substantially depleted. ${ }^{232}$ With paid leave in place, men's work situation would be much like that currently confronted by women, and to the extent they suffered adverse consequences for taking leave, they would have recourse to legal action.

Nevertheless, although providing paid leave for longer periods of time would certainly aid those women who were trying to balance work and family issues, there is little reason to believe such legislation, by itself, would reduce the inequality women face in the workplace. ${ }^{233}$ Even with paid leave legislation, it is unlikely that substantial numbers of men will take the guaranteed level, particularly if they have accrued vacation time available that will allow them to satisfy their apparent preference for a short leave time. Experiences from countries that offer more generous leave policies demonstrate that men remain reluctant to take leave even when the leave is paid. With the important, and partial, exception of Sweden, discussed below, men rarely avail themselves of leave, ${ }^{234}$ and

example, that men may need to avail themselves of sexual harassment doctrine to counter the hostile work environments that confont men who try to take leave. See Malin, supra note 177, at 1089-93 (arguing that sexual harassment law would provide a remedy for men who work in a "FMLA hostile environment).

232 See text accompanying notes 173-82.

233 This is one reason why the proposal by Sam Issacharoff and Elaine Rosenblum to provide for a payroll tax to pay for family leave fails to go far enough. See Issacharoff \& Rosenblum, supra note 130, at 2214-20. Their model for funding for twelve weeks of pregnancy leave is based on the Canadian model and borrows substantially from unemployment insurance schemes. $I d$. at 2216-17. This model is likely to reduce the gender gap somewhat by making it easier for women to return to work after having a child, and therefore create a more continuous work career. Id. at 2164 (emphasizing importance of continuous labor force attachment). See also Waldfogel, supra note 7, at 151-52 (arguing that providing coverage to women might reduce gap associated with having children by $40 \%$ ).

234 As noted previously, men generally take about five days of leave, even though many men have access to some form of paid leave. See supra at text accompanying note 169 and sources cited therein. Based upon a survey of leave patterns in the United States 


\section{Family Leave and the Gender Wage Gap}

even in Sweden the leave legislation has brought fewer benefits than is often assumed.

Sweden is widely cited as having a model leave law, one that has achieved some success in getting men to take leave. ${ }^{235}$ Based on data from the late 1980s, approximately 44 percent of Swedish men take parental leave with the average leave lasting 45 days. ${ }^{236}$ Although these figures are impressive relative to other nations, it is nevertheless important to place them in context. Nearly all Swedish women take leave, and their leave averages 260 days, nearly nine months or six times as long as the men's leave. ${ }^{237}$ In addition to the unequal lengths of leave, most mothers work part-time, at least on their initial return from work, and women with children in the United States are twice as likely to work full-time as similarly situated women in Sweden. ${ }^{238}$ Women in Sweden also remain

and Sweden, Joseph Pleck concludes, "[F]or whatever reason, it is clear that fathers will take advantage of infant care leave to a far lesser extent than mothers. Infant-care leave policies may be gender-neutral in principle but they will not work in a gender-neutral way in practice." Joseph H. Pleck, Fathers and Infant Care Leave, in THE PARENTAL LEAVE CRISIS 184-85 (Edward F. Zigler \& Meryl Frank eds. 1989).

235 For discussions of Sweden's experience as a possible model for the United States see Linda HAAS, EQUAL PARENTHOOD \& Social Policy: A STUdy OF PARENTAL LEAVE IN SWEDEN (1992); Siv Gustafsson \& Frank P. Stafford, Three Regimes of Child Care: The United States, the Netherlands, and Sweden, in SOCIAL PROTECTION VerSUS ECONOMIC FLEXIBILITY: Is THERE A TRADE-OFF? at 333 (Rebecca M. Blank ed., 1995); Arielle Horman Grill, Comment, The Myth of Unpaid Leave: Can the United States Implement A Paid Leave Policy Based on the Swedish Model? 17 COMP. LABOR L.J. 373 (1996); Malin, supra note 177, at 1075-77.

236 See Joseph P. Allen, European Infant Care Leaves: Foreign Perspectives on the Integration of Work \& Family Roles, in THE PARENTAL LEAVE CRISIS 264 (Edward F. Zigler \& Meryl Frank eds. 1989); Linda Haas, Nurturing Fathers and Working Mothers: Changing Gender Roles in Sweden, in MEN, WORK \& FAMILY 248 (1993); Grill, supra note 235 , at $377-78$.

${ }^{237}$ Haas, supra note 236, at 249. The figures Haas cite are for children born in 1989.

238 See Gustafasson \& Stafford, supra note 235, at 348. 
largely absent from managerial provisions even with the generous family leave policies in place. ${ }^{239}$

Despite the persistence of these inequalities, Sweden remains an important case study, if for no other reason than the successful way in which the country has been able to incorporate family leave, and child care, into the accepted employment package. ${ }^{240}$ Sweden enjoys widespread political support for extended parental leave, and publiclyfinanced daycare facilities, both of which have been accepted as part of the comprehensive protection policies that characterize the Swedish social welfare system. ${ }^{241}$ The Swedish model may not translate directly to the United States but it does seem clear that any successful program of family leave will require broad based political support, something that appears to exist in the United States though the policies we have implemented fall short of creating an adequate policy.

\section{Requiring Men to Take Leave.}

Given the likely limited effect of paid leave policies, it will be necessary to take stronger measures to induce greater levels of leave taking. One such proposal would be to require men to take six weeks of leave. This could be done on a temporary basis - say for five years - as a means of trying to change the structured patterns that continue to replicate our gender inequalities through the preservation of gender norms. This suggestion may sound rather extreme, yet the premise underlying the idea is that currently women are effectively required to take leave, and the legislation would simply balance that socially imposed

239 See Dana Milbank, Sweden: Laws Help Mom, But They Hurt Her Career, WALL STREET JOURNAL, July 26, 1995, at B1 ("Women hold only 8\% of private-sector managerial jobs, and they are all but absent from top management.").

240 For example, a Swedish banker commented, "[The leaves are] good for the fathers and mothers, and that must be good for the bank." Joseph P. Allen, supra note 236, at 255 (citation omitted).

241 See Gustafsson \& Stafford, supra note 235, at 346. 


\section{Family Leave and the Gender Wage Gap}

condition with one that was legally imposed.

There are two strong arguments in favor of a mandatory leave policy. First, such a system, if properly enforced, would in all likelihood work, and may strongly influence the prevailing norms regarding working parents, as both men and women would be expected to leave the workplace for a definite period of time following the birth or adoption of a child. Second, on a purely pragmatic level, it may be the only policy that would succeed in inducing large numbers of men to take leave.

A number of objections to a mandatory paternity leave policy would likely arise, including questions regarding its constitutionality on both due process and equal protection grounds. Although I believe that a well-developed program should survive constitutional scrutiny, ${ }^{242}$ a gender neutral proposal may garner greater support with very nearly identical results. Because most, if not all, women would take the available paid leave, requiring such leave of both men and women would ameliorate

${ }^{242}$ Without going into detail, I will sketch an argument that a gender-specific requirement that men take leave would be constitutional (which is, of course, quite different from saying that the Supreme Court would uphold such a policy). Gender-based restrictions need only satisfy the Court's intermediate scrutiny, which requires establishing that the program was designed to serve an important governmental objective and that the chosen means were substantially related to the achievement of the objective. See Mississippi University for Women v. Hogan, 458 U.S. 718 (1982). In the area of gender classification, one of the Court's central concerns is that the legislation not perpetuate gender stereotypes. Id. at 725. Requiring men to take leave could run afoul of the Court's concern with gender stereotypes; however, in this instance the act is based on an empirical, and well documented, reality rather than a stereotype, namely that men rarely take leave and that the gendered nature of leave taking substantially contributes to labor market inequality. The harm women suffer as a result of the existing patterns is also welldocumented, and both of these facts should lend credence to the government's claim that the legislation is aimed at advancing an important governmental interest, namely gender equality. Similarly, it should be possible to establish that mandatory leave is the only means possible to break up the patterns, and if the statute includes a defined time period, the Court should be even more receptive to upholding the provision as a temporary measure aimed at correcting a manifest imbalance in the workplace. $C f$. Johnson v. Transportation Agency, 480 U.S. 616 (1987) (upholding gender preference). Let me reiterate that this is simply a brief and by no means conclusive or persuasive explication of what is a complicated and by necessity nuanced argument. 


\section{Family Leave and the Gender Wage Gap}

the constitutional concerns while affecting the choices of very few women. ${ }^{243}$ This form of a gender neutral proposal may, however, harken to the days when pregnant women were often required to leave the workplace both before and after giving birth, ${ }^{244}$ and for this reason may prove politically undesirable. There are also important questions regarding administrability, in particular whether the statute would apply to all fathers, only those who are married to the mother, or who are living at home with the mother. For these reasons, it is important to propose additional incentives to get men to take leave that can be accomplished through less drastic means, as discussed more fully in the next section.

\section{Creating a Set-Aside Program for Family Leave.}

Perhaps the most promising of the less drastic measures would be to tie federal contracts to employer's records regarding the utilization rates of their parental leave policies. For example, employers who have a strong record of men taking leave, one that exceeds comparable employers, might be incorporated into the existing government programs for providing contracts to disadvantaged businesses. ${ }^{245}$ Again, to meet

${ }^{243}$ A gender neutral policy still must satisfy the Court's rational basis scrutiny, but given that the policy would be intended to serve the important goal of reducing gender inequality, this should not be a difficult standard to meet. Similarly, whatever liberty concerns might arise should be mitigated by the realization that large numbers of workers, truck drivers and airline pilots for example, are prevented from working for specific periods. See 14 C.F.R. § 121.481(c) (1999) (restricting pilots to flying 8 hours during 24 consecutive hours); 49 C.F.R. $\$ 395.3$ (limiting hours drivers can work). If men were required to take leave, they could not be required to engage in any particular activities, such as childcare, but would instead be free to do whatever they pleased other than work for their employer.

${ }^{244}$ See Nashville Gas Co. v. Satty, 434 U.S. 136 (1977) (requiring women about to give birth to take leave of indeterminate length); Cleveland Board of Educ. v. LaFleur, 414 U.S. 632 (1974) (requiring leave five months before expected birth and at least three months after).

${ }^{245}$ The federal government currently has a number of contract set-aside programs in place. The Small Business Administration administers the program known as Section 8(a), which promotes government contracting with minority businesses. See 15 U.S.C. $\S$ 


\section{Family Leave and the Gender Wage Gap}

any objections relating to a gender specific program, there is a readily available gender neutral program that would serve the purpose of rewarding employers for enticing their male employees to take leave. Participation in the set-aside programs could be triggered when a specified percentage of male and female employees have availed themselves of the paid leave programs. For example, an employer might be certified as eligible to participate in the program after fifty percent of their eligible male and female employees have taken at least six weeks of leave, and their continued participation would be tied to maintaining a specified level of leave taking. ${ }^{246}$ Again, since women are likely to satisfy the requirement for paid leave, the gender neutral standard would effectively be triggered by the participation of the male employees. ${ }^{247}$ To avoid crowding out minority and other contractors who currently participate in the program, either a separate family leave set-aside could be created or the goals that currently exist could be increased so as to accommodate the new bidders.

An alternative approach would be for the government to require employers to provide paid leave to their employees , and to ensure that a minimum of fifty percent of their eligible male and female employees take the leave, in order to qualify for federal contracts of a

644 (1999). For a comprehensive overview of federal affirmative action programs, including various set-aside progrms see GEORGE STEPHANOPOLOUS \& CHRISTOPHER EDLEY, JR., AFFIRMATIVE ACTION REVIEW: REPORT TO THE PRESIDENT (1995).

246 If this kind of program were implemented, an employer would submit documentation showing what percentage of its employees were eligible for the leave, the number who took the leave, and the length of the leave. The employer would then have to submit annual reports indicating that it has maintained sufficient participation in its leave program. This requirement would be similar to the continuing certification requirements under the Small Business Administration programs.

247 A skeptical court might view such a program as a pretext for sex discrimination, in which case the program may have to be justified along the lines suggested in note 242 supra. 
certain size, akin to the existing Executive Order program. ${ }^{248}$ Local and state governments might also tie their contracts to similar programs, as is occurring increasingly for a variety of causes ranging from domestic partner benefits to requirements that employers provide a so-called living wage to their employees. ${ }^{249}$

It is difficult to know just how well a set-aside program might work to reduce inequality and change gender norms. Currently, the government awards billions of dollars annually to disadvantaged businesses through various contracting programs, ${ }^{250}$ and most studies indicate that the existing programs have significantly increased opportunities for women and minority contractors. ${ }^{251}$ Perhaps of equal

248 Pursuant to Executive Order 11,246, 30 Fed. Reg. 12,319 (1965), and the implementing regulations, contractors with fifty or more employees and contracts of $\$ 50,000$ or more must implement affirmative action programs.

249 San Francisco requires its contractors to provide benefits to domestic partners. See Carla Mainucci, S.F.'s New Partners Law Called Rousing Success, S.F. CHRONICLE, Jan. 7, 1998, at A13. In the last several years, a number of jurisdictions have required their contractors to provide a living wage and it is now estimated that two dozen cities have enacted such laws, with many more currently considering the idea. See, e.g., Ron DePasquale, Council Unanimously Approves Living-Wage Measures, BuFfaLO NEWS, July 28, 1999, at 5B; Sarah Fishman, A Living Wage Takes Effect in Somerville, BosTON GlOBE, July 25, 1999, at 17; Scott Wilson, Compromise Living-Wage Bill Offered in Montgomery, WASH. PosT, July 21, 1999, at B4; Nicholas Riccardi, Living Wage OK'D By County Supervisors, L.A. TIMES, June 16, 1999, at 1.

250 See Ian Ayres \& Frederick E. Vars, When Does Private Discrimination Justify Public Affirmative Action? 98 COLUM. L. REV. 1577, 1590-94 (1998) (discussing amount of dollars awarded to disadvantaged businesses). Under the Small Business Administration's Section 8(a) Minority Enterprise Development Program more than \$6 billion is awarded annually to participating firms. See U.S. SMALL BUSINESS ADMIN., OFFICE OF MINORITY ENTERPRISE DEVELOPMENT, RPT. TO CONGRESS ON MINORITY SMALl BusinesS AND CAPITAL OWNERSHIP DEVELOPMENT FOR FISCAL YEAR 1997 at 26 (1998).

251 See Ayres \& Vars, supra note 250, at 1592 (noting that "MBEs were actually 33 percent more likely to sell to the government than were nonminority firms."); John Lunn \& Huey L. Perry, Justifying Affirmative Action: Highway Construction in Louisiana, 46 INDUS. \& LABOR REL. RVW. 464, 475 (1993) (finding that federal requirement to include 


\section{Family Leave and the Gender Wage Gap}

importance, these programs have become an integral part of the debate on racial, and to a lesser extent gender, equality, and are now largely enmeshed as part of our government procurement process. ${ }^{252}$ Including family leave as part of that national dialogue would thus serve important political interests and may help us rethink our existing policies that place the onus of child rearing on women. Another significant advantage of a set-aside program is that such a program places the incentive with employers to encourage their employees to take leave, rather than relying on employees to take action. As a result, employers would be far less likely to penalize their employees for taking leave since they will stand to benefit from the policy, and consequently men should no longer fear that they will be ostracized or penalized if they take their available leave.

With this in mind, inducing substantial numbers of men to take parental leave through a set-aside policy would have at least three important salutary effects. First, it would inject noise into the signal employers currently use to discriminate against women based on their projected labor force attachment, and thereby make the signal even less accurate and presumably less valuable for employers. Once men begin to take leave, employers will be far less inclined to penalize their employees, and will no longer be able to assume that women will bring

DBEs in highway construction contracts increased representation of minority and womenowned firms in Louisiana); Samuel L. Myers, Jr. \& Tsze Chan, Who Benefits from Minority Business Set-Asides? The Case of New Jersey, 15 J. OF POLICY ANALYSIS \& MGT. 202, 215 (1996) (finding that both the number of bids submitted and the contracts awarded increased significantly with set-asides); William Rodgers III \& William E. Spriggs, The Effect of Federal Contractor Status on Racial Differences in EstablishmentLevel Employment Shares: 1979-1992, AMERICAN ECON. RVw. PAPERS AND PROCEEDINGS 290, 292 (1996) (finding that federal contractors increased hiring of African Americans).

${ }^{252}$ Indeed, even though the set-aside programs have been under attack by a hostile congress for a number of years, efforts to repeal the programs have been unsuccessful. See James Dao, Senate Stops Bid to End Road-Work-Set-Asides, N.Y.TIMES, Mar. 7, 1998, at A9 (noting that the "Senate strongly rejected an effort today to end a two-decade old program ..."). 
a disadvantage to the labor force that distinguishes them from men. This is, in large measure, what occurred during the litigation over fetal protection policies where companies sought to restrict their female, but not their male employees, from jobs where they would be exposed to high levels of lead, even though both men and women were exposed to harmful levels in the workplace. When the Supreme Court struck down those policies, as a form of gender discrimination employers had a far stronger incentive to reduce lead levels for all of their employees because the relatively easy option of excluding women was no longer available. ${ }^{253}$ But such an effect can only occur if substantial, rather than token, numbers of men begin to take leave.

Relatedly, once more men begin to take leave, it may be possible to create a greater coalition for incorporating family leave into the workplace package of benefits. A primary reason family leave remains a secondary or tertiary benefit is that it currently applies only to women, and most employers do not feel a need to change their policies to attract more workers. ${ }^{254}$ But if men began to take leave at levels that were commensurate with their stated interest, and if the issue thus became one that affected all workers rather than just female workers, then we may see family leave become part of the standard package of benefits, just like health insurance or workers' compensation. This is, in fact, the process that led to the adoption of workers compensation legislation, which arose at the turn of the century as a result of the emergence of a broad confluence of interests between workers and employers. ${ }^{255}$ In the United

${ }^{253}$ See International Union, UAW v. Johnson Controls, Inc., 499 U.S. 187 (1991). For a recent discussion of the case and the important role the union played see DRUCILla CORNELl, AT THE HEART OF FREEDOM: FEMINISM, SEX AND EQUALITY 72-81 (1998).

254 As Deborah Rhode has argued, "As long as work and family conflicts remain primarily 'women's' issues, they are unlikely to receive adequate attention in decisionmaking structures dominated by men." Rhode, supra note 136, at 592.

255 See Price V. Fishback \& Shawn Everett Kantor, The Adoption of Workers' Compensation in the United States, 1900-1930, 41 J. OF LAW \& ECON. 305 (1998) (arguing that workers compensation legislation succeeded where other progressive 


\section{Family Leave and the Gender Wage Gap}

States, this is likely to occur only when employers realize that the costs of allowing workers to take leave are not as high as perceived and hold significant returns in loyalty and productivity. ${ }^{256}$ However, this information can only be provided through experimentation, which will require broader use of leave by both men and women.

Finally, and in some ways most important, the proposal effectively treats women, or more accurately the taking of leave at the time of the birth of a child, as the norm. Rather than requiring women to act like men as a means of moving toward equality, the idea advanced here requires men to act more like women, and thereby seeks to alter our workplace expectations so that employers will expect their employees to take some significant leave following the birth of a child. Taking this step forward may go a long way to dissecting our existing gender norms and thereby reduce some of the inequality that currently results from perceptions that are not supported by the data. ${ }^{257}$ Along the same lines, changing the norms should help us move to a day when we no longer talk about female and male employees, or their distinct work patterns, but

legislation failed because it received support from broad range of interest groups); Shawn Everett Kantor \& Price V. Fishback, Precautionary Saving, Insurance and the Origins of Workers' Compensation, 104 J. POL. ECON. 419 (1996) (detailing the various benefits groups obtained through legislation).

256 Although the data on the productivity gains from paid family leave policies are limited, many have argued that such policies will ultimately enhance worker productivity. See WEVER, supra note 7, at 27 (arguing that paid leave increases employee morale and reduces turnover). The inertia described earlier, coupled with the lack of good information, may currently prevent more employers from adopting policies, and mandating the leave may expedite the development of efficient policies. $C f$. John J. Donohue, III, Is Title VII Efficient? 134 U.PA. L. REV. 1411 (1986) (arguing that antidiscrimination laws decrease profits of discriminators faster than the market).

${ }^{257}$ Nancy Fraser has recently sought to create a similar model that combines the best features of the competing equality and difference models that still occupy too much of feminist theory. Fraser concludes, "The key to making gender equity in a postindustrial welfare state . . is to make women's current life-patterns the norm for everyone." FRASER, supra note 19, at 61. For a similar argument regarding the development of sexual harassment law see Kathryn Abrams, Gender Discrimination and the Transformation of Workplace Norms, 42 VAND. L. REV. 1183 (1989). 


\section{Family Leave and the Gender Wage Gap}

instead can move to a less gendered work sphere.

Requiring employers to provide six weeks of paid leave would almost certainly be met by vigorous opposition by employers, and their representative groups, who would object to the potential costs of such a mandate. ${ }^{258}$ However, the costs of the proposal should not be ruinous, and quite possibly would not even be all that substantial. Currently, many employers provide forms of paid leave through other existing policies such as sick leave and vacation time, and most women take advantage of whatever leave is available to them. For these employers, a mandated paid leave provision would simply shift the leave taking from one realm to another with the additional costs arising from the increased numbers of men who take leave. ${ }^{259}$ It has been estimated that California's mandate to fund family leave through its disability insurance program added about 20 percent to the costs of that system. ${ }^{260}$ Even assuming a higher cost, say doubling the cost of disability insurance, the burden would still fall below that currently required by workers compensation, as disability insurance is one of the lowest cost benefits offered by employers.

Some portion of these costs would likely be passed onto

258 The early versions of what ultimately became the FMLA contained provisions for wage replacement but these provisions were quickly dropped in face of strong business opposition. See Marks, supra note 192, at 59-60 (discussing early history and its opposition by business leaders).

259 Any legitimate concern about increased costs could be met by amending the FMLA so that sick leave could be used for FMLA on a discretionary basis for the six weeks of paid leave. Even under existing law employers have flexibility to require their employees to take various forms of leave before they utilize the unpaid leave provided by the FMLA. See 29 U.S.C. \$2602(d).

260 See WeVER, supra note 7, at 14. Based on California's experience with disability insurance, Wever calculated that a mandatory 54\% wage replacement for would cost about $\$ 1.5$ billion for California to cover all forms of currently available FMLA leave. $I d$. 


\section{Family Leave and the Gender Wage Gap}

employees in the form of lower wages. ${ }^{261}$ Although this may appear to be a significant disadvantage to the proposal, this effect is not unique to family leave but is equally true for other workplace mandates, such as workers' compensation or health insurance. ${ }^{262}$ A significant advantage of a set-aside program is that the costs are likely to be absorbed primarily by the government and thus shared more broadly by its citizens. But given that there is nothing unique about the costs of family leave, the proper question is whether these costs are a trade-off we are willing to make in order to reduce gender inequality in the workplace. As previously noted, the survey data suggest that workers strongly support paid leave provisions, ${ }^{263}$ and even if that were not the case, as a society we need to make a judgment regarding the importance of incorporating

261 This was the finding of Jonathan Gruber's study of the effects of state mandates requiring the coverage of childbirth expenses in employer-provided insurance. See Jonathan Gruber, The Incidence of Mandated Maternity Benefits, 84 AMER. ECON. REV. 622 (1994). Others estimate that there will only be a small effect on wages as a result of family leave mandates. See Waldfogel, supra note 7, at 152 \& n.17 (discussing studies). For additional discussions see Richard Craswell, Passing on the Costs of Legal Rules: Efficiency and Distribution in Buyer-Seller Relationships, 43 STAN. L. REV. 361, 389 (1991) (discussing effects of mandatory product warranties for consumers); Jonathan Gruber \& Alan B. Krueger, The Incidence of Mandated Employer-Provided Insurance: Lessons from Workers' Compensation Insurance 112, in TAX POLICY AND THE ECONOMY (D. Bradford ed. 1991); Christine Jolls, Cass R. Sunstein, Richard Thaler, A Behavioral Approach to Law and Economics, 50 STAN. L. REV. 1471, 1492 (1998) (relying on the endowment effect to explain the ability to pass the costs onto employees); Lawrence Summers, Some Simple Economics of Mandated Benefits, 79 AMER. ECON. REV., PAPERS \& PROCEEDINGS 177 (1989).

${ }^{262}$ Gruber and Krueger estimate that $85 \%$ of the cost of workers' compensation insurance was borne by workers, and that the cost borne by employers likely reduced employment by $.11 \%$, or a little more than 100,000 jobs for the 90 million workers covered. See Gruber \& Krueger, supra note 261, at 134. A recent study of Hawaii's legislation mandating that employers provide health insurance found that much of the cost of the program was passed onto workers in the form of lower wages but that there was no apparent suppression of labor demand. See Norman K. Thurston, Labor Market Effects of Hawaii's Mandatory Employer-Provided Health Insurance, 51 INDUS. \& LABOR REL. Rvw. 117 (1997).

263 See NAT'L PARTNERSHIP ON WOMEN AND FAMILIES, supra note 13, at 2. 


\section{Family Leave and the Gender Wage Gap}

family leave into the standard package of benefits offered to employees. ${ }^{264}$ After all, many employees would likely express a willingness to work in hazardous conditions for greater pay; yet, the workplace is closely regulated to reduce those hazards despite the effect the regulations have on labor demand. Accordingly, we need to get beyond the notion that only costless programs are politically feasible; as we saw in the discussion of the FMLA, costless programs generally provide commensurate benefits. If we are interested in improving the equality of women in the workplace, then the costs of a set-aside program or of requiring men to take leave, will be well worth the costs, and in the long run will offer far more in return.

\section{CONCLUSION}

At some point, something is going to have to give: either women are going to have give up the hope of true workplace equality, and relegate themselves to the predominate position of secondary status within the workplace, or we will need to develop policies that relieve the existing penalty imposed on women for their probability, and the reality of, having children. As discussed in this article, improving women's human capital, or trying to change women's employment behavior in other ways, is unlikely to lead to greater progress, and something more is needed. In this article, I have advocated that we find ways to encourage, or induce, men to take leave surrounding the birth of a child, and that we do so through providing a minimum of six weeks of paid leave and creating a contract set-aside program that will reward employers for encouraging their employees to take family leave. Making these changes would only be a start on the road to greater equality, but it would be an important, step, indeed I believe the most important, we could make toward greater workplace equality and one that would be worth the costs of the proposal.

264 This phenomenon appears to have occurred in other countries. For example, when asked about the costs of the extended leave mandated in Germany, one employer noted, "[W]e don't think about it, your question is like asking how we feel about workers receiving Sunday as a day off." Allen, supra note 236 at 257. 